RO $\mathrm{O} M$ Life Sciences Miscellaneous Publications Royal Ontario Museum

\title{
Evolution of Archeopyle and Tabulation in Rhaetogonyaulacinean Dinoflagellate Cysts
}

Gunter Dörhöfer

Edward H. Davies

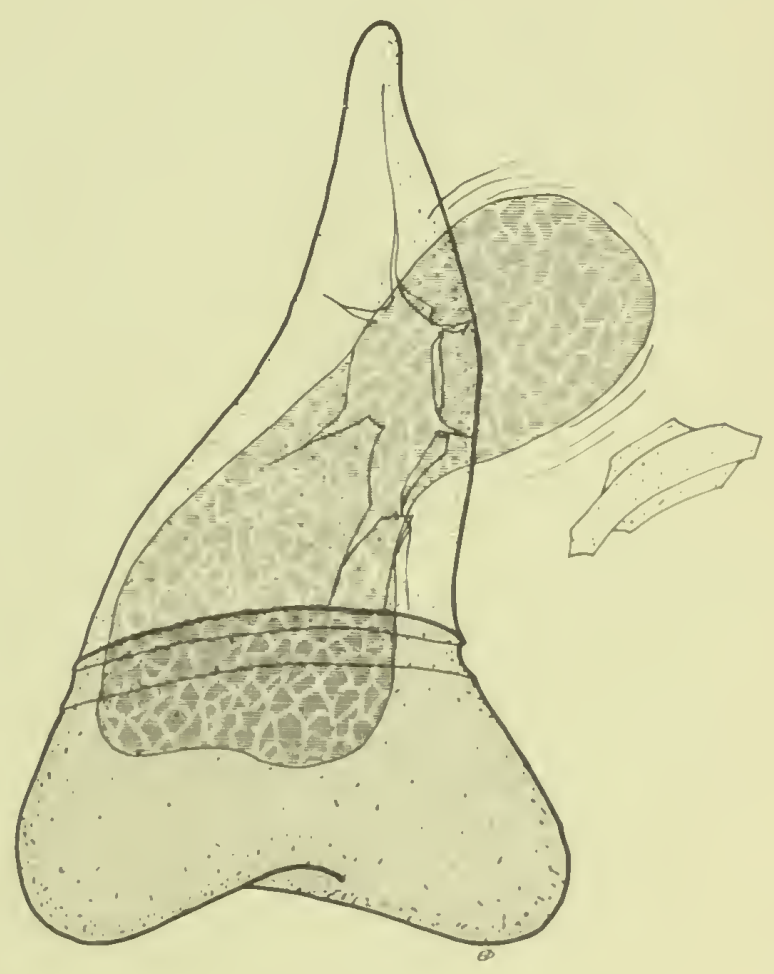


Digitized by the Internet Archive in 2012 with funding from Royal Ontario Museum

http://archive.org/details/evolutionofarche00drhf 
GUNTER DÖRHÖFER EDWARD H. DAVIES

\section{Evolution of Archeopyle and Tabulation in Rhaetogonyaulacinean Dinoflagellate Cysts}




\section{ROYAL ONTARIO MUSEUM \\ PUBLICATIONS IN LIFE SCIENCES}

The Royal Ontano Museum publishes three series in the Life Sciences:

LIlt: SCIENCES CONTRIat TIONS, a numbered series of original scientific publications including monographic works.

LIFL SCIENCES OCCASIOYAI PAPERS, a numbered series of original scientific publications, primarily short and usually of taxonomic significance.

LIFI: SCIEYCES MISCLLLAVEOL'S PLBLICATIONS, an unnumbered series of publications of varied subject matter and format.

All manuscripts considered for publication are subject to the scrutiny and editorial policies of the Life Sciences Editorial Board, and to review by persons outside the Museum staff who are authorities in the particular field involved.

I.JFE SCIENCES EDITORIAL HOARD

Senior Editor: J.H MA ANIJRE:WS

Editor: $R$ D JAMES

Editor: C MCGOWAN

GI NTI:R IORHOFER was a postdoctoral fellow of the Department of Geology, University of Toronto, and is with the Bundesanstalt für Geowissenschaften und Rohstoffe, Niedersächsisches Landesamt für Bodenforschung, D-3 Hannover 51, Stilleweg 2, Postfach 5101 53, West Germany.

IDWARD H DAVIES was a postgraduate student of the Department of Geology, University of Toronto, and is with Phillips Petroleum Company, Bartlesville, Oklahoma 74004, USA

Cover drawing: The excystment of Phallocista (as envisioned by the second author E.H.D.)

\section{Canadian Cataloguing in Publication Data}

Dörhöfer, Gunter, 1946-

Evolution of archeopyle and tabulation in

Rhaetogonyaulacinean dinoflagellate cysts

(Life sciences miscellaneous publications ISSN

0082-5093)

Bibliography: p.

ISBN 0-88854-239-9

1. Dinoflagellata, Fossil. 2. Paleontology -

Mesozoic. 3. Evolution. 4. Paleontology - Arctic

regions. 5. Paleontology - Germany. I. Davies,

Edward H., 1950- II Royal Ontario Museum.

III Title. IV. Series: Life sciences miscellancous

publication.

QE774.D5D64 563'.1 C80-094086-5

QL1. T6539

(C) The Royal Ontario Museum, 1980

I00 Qucen's Park. Toronto, Canada M5S 2C6

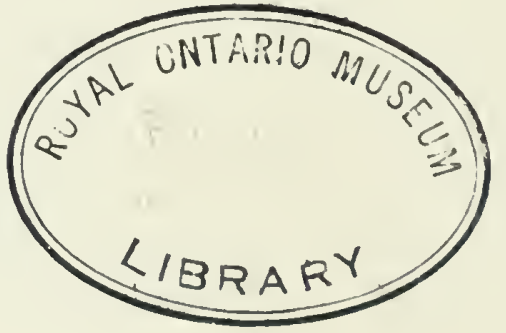




\section{Contents}

Abstrict 5

Introduction 5

Imbrication, the Keystone Principle and Archeopyle Formation 6

Plate Series and Plate Designations 7

Terminology 8

Materials and Methods 8

Stratigraphic Review of Cyst Characters of Pertinent Genera 9

Triassic-Lower Jurassic Dinotlagellates

Suessia Morbey 197510

Rhaetogonvaulax Sarjeant emend. Harland et al. 197510

Heibergella Bujak and Fisher $1976 \quad 11$

Dapeodinium Evitt $1961 \quad 11$

Sierdrupiella Bujak and Fisher $1976 \quad 11$

Voricysta Bujak and Fisher 1976 emend. 11

Heberisa Bujak and Fisher $1976 \quad 11$

Late Early Jurassic and early Middle Jurassic Dinotlagellates 11

Comparodinium Morbey 197511

Dodekovia gen. nov. 11

Phallocista gen. nov. 11

Susadinium gen. nov. 12

Pareodiniacean Cysts (Middle Jurassic-Lower Cretaceous) 12

Pareodimia Deflandre $1975 \quad 12$

Glomodinium Dodekova $1975 \quad 12$

Paragonvaulacista Johnson and Hills 1973 emend. 12

Komewuia Cookson and Eisenack 196012

Netrelveron Sarjeant 196112

Gochteodinia Norris 1978b 12

Pseudoceratiacean Cysts (Upper Jurassic-Lower Cretaceous) 12 Imbatodinium Vozzhennikova $1967 \quad 13$

Aptea Eisenack $1958 \quad 13$

Pseudoceratium Gocht $1967 \quad 13$

Muderongia Cookson and Eisenack 1958; Phoberocvsta Millioud $1969 \quad 14$

Odontochitina Deflandre 193514

Temua Eisenack 1958; Doidyx Sarjeant 1966; Cammingia Cookson and Eisenack 1960;

Ciclonephelium Deflandre and Cookson 195514

Intercalary Plates and Horn Development in Pseudoceratiacean Cysts 15

Intercalary Plates 15

Horn Positions: Antapical versus Postcingular 15

Discussion 16

Systematic Palaeontology 22

Remarks on Suprageneric Classification 22

Description 23

Family Rhaetogonyaulacaceae Norris emend. 23

Dapcodinium Evitt emend. 23

Dapcodinium inornatum (Morgenroth) comb. nov. 23

Dapcodinium semirabularum (Morgenroth) comb. nov. 23

Dapcodinium wapellerse (Pocock) comb. nov. et emend. 23

Noricista Bujak and Fisher 1976 emend. 23

Voricista fimbriata Bujak and Fisher 1976 emend. 24

Sierdrupiella Bujak and Fisher 197624

Sierdrupiella sabinensis Bujak and Fisher 1976

Family Phallocystaceae fam. nov. 24

Comparodinium Morbey emend. Wille and Gocht 24

Comparodinium aquilonium sp. nov. 24

Dodekovia gen. nov. 26

Dodekovia sizigia sp. nov. 26

Dodekoria gochrii (Dodekova) comb. nov. 26

Phallocista gen. now. 26

Phallocista eumekes sp. nov. 27 
Susadinium gen. nov. 28

Susadimium scrofoides sp. nov. 28

Family Pareodiniaceae Gocht emend. 30

Gocheodinia Norris 1978b 30

Gocheodinia villosa (Vozzhennikova) Norris 1978b 30

Gochteodinia verrucosa (Vozzhennikova) comb. nov. 30

Komewuia Cookson and Eisenack $1960 \quad 30$

Komewia diceras (Cookson and Eisenack) comb. nov. 30

Komewuia glabra Cookson and Eisenack 196031

Paragomvandacista Johnson and Hills emend. 31

Paragonvaulacista calloviensis Johnson and Hills emend. 31

Paragonvaulacista retiphragmata sp. nov. 31

Pareodinia Deflandre emend. Gocht 197032

Family Pseudoceratiaceae Eisenack emend. 33

Aptea Eisenack emend. Davey and Verdier emend. 33

Aprea polymorpha Eisenack emend. 34

Canningia Cookson and Eisenack emend. 36

Heterosphacridium Cookson and Eisenack 196836

Heterosphaeridium heteracanthum (Deflandre and Cookson) Eisenack and Kjellström 197136

Imbarodinium Vozzhennikova emend. 36

Imbatodimium kondratjevi Vozzhennikova emend.

Imbatodinium exiguum (Alberti) comb. nov. 37

limbatodinium gochtii (Alberti) comb. nov. 37

Imbatodinium jaegeri (Alberti) comb. nov. 37

Imbatodinium longicornutum (Alberti) comb. nov. 37

Imbatodinium micropodum (Eisenack and Cookson) comb. nov. 37

Imbatodinium pelliferum (Alberti) comb. nov. 38

Imbatodinium sp. 38

Odomochitima Deflandre emend. Davey $1970 \quad 39$

Odomochitina operculata (O. Wetzel) Deflandre and Cookson 195539

Odontochitina muda (Gocht) comb. nov. 39

Pseudoceratium Gocht emend. 39

Pseudoceratium pelliferum Gocht emend. 39

Family Batiacasphaeraceae fam. nov. pro. 39

Batiacasphaera Drugg emend. 40

Batiacasphaera circularis (Cookson and Eisenack) comb. nov. 40

Batiacasphaera capitata (Cookson and Eisenack) comb. nov. 40

Batiacasphaera echinata (Gitmez and Sarjeant) comb. nov. 40

Batiacasphaera mimor (Cookson and Hughes) comb. nov. 40

Batiacasphacra pilosa (Ehrenberg) comb. nov. 40

Batiacasphaera ringnesii (Manum and Cookson) comb. nov. 40

Batiacasplacera rioulti (Sarjeant) comb. nov. 41

Batiacasphaera rotundata (Cookson and Eisenack) comb. nov. 41

Batiacasplaera taugourdeaui (Varma and Dangwal) comb. nov. 41

Batiacasphaera torulosa (Davey and Verdier) comb. nov. 41

Batiacasphaera verrucosa (Sarjeant) comb. nov. 41

Batiacasplaera villersense (Sarjeant) comb. nov. 41

Family Areoligeraceae Evitt emend. Sarjeant and Downie 41

Cyclonephelium Deflandre and Cookson emend. 41

Summary and Conclusions 42

Acknowledgements 42

Literaturc Cited 43 


\title{
Evolution of Archeopyle and Tabulation in \\ Rhaetogonyaulacinean Dinoflagellate Cysts
}

\begin{abstract}
Jurassic to Lower Cretaceous dinoflagellate cysts from Arctic Canada and Germany demonstrate evolutionary lineages from a Triassic ancestral stock (Rhaetogonyaulaxtype). These lineages are based on archeopyle formation, tabulation, and horn development. The evolution of archeopyles can be interpreted as an overlap scheme (imbrication) of plate boundaries. Initial archeopyle formation tends to remain stable through time in the preferred mid-dorsal keystone position. Earliest cyst genera formed disintegration archeopyles which later genera stabilized into fused opercular pieces of definite position, representing all major archeopyle types. A lineage within the Suborder Rhaetogonyaulacineae was developed from the Triassic ancestral stock through the Early to Middle Jurassic phallocystacean cysts, then through the pareodiniacean cysts of the Middle Jurassic to Early Cretaceous times through to the pseudoceratiacean cysts of the Late Jurassic to Early Late Cretaceous. The Pseudoceratiaceae have two intercalary plates within the operculum resulting in the asymmetrical archeopyle suture. Relevant genera of the Rhaetogonyaulacineae are reviewed and reinvestigated using scanning electron and interference contrast microscopy. The families Pseudoceratiaceae, Rhaetogonyaulacaceae, and Pareodiniaceae are emended. The families Phallocystaceae and Baticasphaeraceae are proposed. The first four families together constitute the suborder Rhaetogonyaulacineae. Three new genera are proposed: Dodekovia, Phallocysta, and Susadinium. Nine genera are emended: Aptea, Batiacasphaera, Canningia, Cyclonephelium, Dapcodinium, Imbatodinium, Noricysta, Paragonyaulacysta, and Pseudoceratium. Five new species are proposed: Comparodinium aquilonium, Dodekovia syzygia, Paragonyaulacysta retiphragmata, Phallocysta eumekes, and Susadinium scrofoides.
\end{abstract}

(dinoflagellata; archeopyle; evolution; Mesozoic; Canada; Germany; SEM)

\section{Introduction}

Studies on the phylogeny and evolution of dinoflagellates are lacking in previous palynological literature. The following hypotheses attempt to fill this void and to stir interest in dinoflagellate evolution.

Norris (1978a, b) revised the classification of dinoflagellate cysts at the suprageneric level. He recognized four suborders based mainly on archeopyle types. These are the Rhaetogonyaulacineae, Hystrichosphaeridiineae, Gonyaulacystineae, and the Deflandreineae. We have investigated most genera of the rhaetogonyaulacinean suborder from the Jurassic-Cretaceous of the Sverdrup Basin, Arctic Canada and from the northwest German Neocomian. This work has revealed evidence on archeopyle and tabulation evolution.

Within the suborder Rhaetogonyaulacineae Norris (1978a, b) recognized three families, the Rhaeto- 
gonyaulacaceae, Sverdrupiellaceae, and Pareodiniaceae, which he differentiated mainly by distinct tabulation pattern, presence of pericoels, and smooth autophragm respectively. The classification did not include further details on archeopyle formation within the suborder.

The classification incorporates a concept of dinoflagellate evolution from ancestral rhaetogonyaulacacean through pareodiniacean cysts to members of the suborders Deflandreineae and Gonyaulacystineae. Members of the suborder Hystrichosphaeridiineae were thought to have been derived from early forms in the Late Triassic. According to Norris (1978a, b) the earliest known dinoflagellate cysts are characterized by "suessioid" tabulation, namely one "in which plate number is high and variable, the diagnostic character being a well developed anterior intercalary series, some or all of which form an archeopyle" (Norris, 1978a, :306). It was our intent to trace the development of important morphological characters along phylogenetic paths. The studies of Late Triassic and Early Jurassic dinoflagellate cysts indicate links between early suessioid genera and later pareodiniacean cysts. The studies on Early Cretaceous material have shown that this trend continues to the pseudoceratiacean cyst types.

The principles on which the phylogenetic patterns are based, namely imbrication and the keystone principle and their relationship to archeopyle formation as well as the terminology used, are discussed to lay the foundation for the critical examination of generic relationships. The morphological and structural characters of each pertinent genus are reviewed in ascending stratigraphic order to acquaint the reader with the fossil record of rhaetogonyaulacinean dinoflagellate cysts. The discussion of those genera sketches the phylogenetic paths taken during the evolution of the Rhaetogonyaulacineae from the Triassic through to the Early Cretaceous and suggests possible radiation to other basic cyst types. A systematic section circumscribes and itemizes the taxonomic concepts of families, genera, and species used to support the hypotheses proposed.

\section{Imbrication, the Keystone Principle and Archeopyle Formation}

Both tabulation and mode of archeopyle formation have been recognized as being of prime importance for the evolution and classification of dinoflagellate cysts (Evitt, 1967; Norris, 1978a). Gocht and Netzel $(1974,1976)$ and Dürr and Netzel (1974) have also presented direct evidence from the fine thecal structure of modern dinoflagellates. They showed the presence of an overlap pattern of plates in both Gonyulax polyedra Stein (Dürr and Netzel, 1974) and several species of Peridinium Ehrenberg (Gocht and Netzel, 1974, 1976). Beginning with plate 1', each successive plate, proceeding from ventral to dorsal position on both right and left sides, overlaps the adjacent plate like shingles on a roof. This structure is closed in mid-dorsal position, in Peridinium by plates 2a and $4^{\prime \prime}$ and in Gonyaulax by plate $3^{\prime \prime}$. The precingular plates are attached to the cingular plates by an "adcingular Falz" (adcingular lap-joint), a griplike structure on the cingulum. Plate 4 " in Peridinium and plate $3^{\prime \prime}$ in Gonvaulax are the "Firstziegelplatten" (keystone plates). A similar overlap scheme is developed on the hypotract starting with $1 p$ and ending with plate $3 "$ '.

The overlap scheme as recognized by Gocht and Netzel (1974:394-397) is here termed imbrication, referring to the order of plate boundary overlap on dinoflagellate cysts and thecae. Gocht and Netzel (1976) pointed out that the keystone position corresponds to the archeopyle position in cysts. They emphasized the importance of the adcingular lap-joints in determining the archeopyle mode and position. If the lap-joints are strong, intercalary or apical archeopyles can be formed instead of the keystone (precingular) types. In Peridinium the precingular plates are firmly attached to the adcingular lap-joint leaving plate $2 \mathrm{a}$ as the next preferred position for archeopyle formation in the overlap scheme. Gocht and Netzel (1976) suggest that in the early evolution of cysts the theca was still attached to the cyst during excystment and the archeopyle in the cyst would therefore correspond in a functional manner to the thecal keystone. However, such an explanation is not necessary, as it is evident from other thecal features which are "repeated" on the cyst body without any functional relation, "that the morphogenesis of theca and cyst wall did occur independently from each other, but is related to a similar cortical differentiation of the cell wall"' (transl. from Berthold et al., 1976:330). This suggests a genetic control of cortex development, e.g. of both the thecal amphiesma (Loeblich, 1970) and the cyst phragma.

Boltovskoy (1973) showed that under adverse conditions thecae of several Peridinium species form "archeopyles", which are similar in position to the archeopyle of the corresponding cysts. The (AIP) archeopyle observed on the thecae only differs from the (AIP) cyst archeopyle in that the dorsal half of the epitheca is completely removed, whereas in the cysts the operculum is attached adcingularly. (We follow the Evitt System of symbols for archeopyle terminology but with the improvements outlined in Norris (1978a:303), including the procedure of indicating compound opercular pieces by parentheses instead of superscript bars.)

In our examination of archeopyles we noted that the keystone principle is applicable to fossil cysts from the earliest forms. Detailed scanning electron photomicrographs of Gonyaulacysta aldorfense Gocht 1970 (Gocht, 1970: pl. 30) and Histrichosphaeropsis quasi-cribrata (O. Wetzel) Gocht 1976 (Gocht, 1976: figs. 14, 15) suggest imbrication and the keystone principle in fossil cysts, similar to thecae where "an external suture line can 
be discerned which is parallel but of fset with respect to the internal suture line" (Gocht and Netzel, 1974:381).

Imbrication in cysts is demonstrated in the archeopyle formation of Rhaefogonvaulax: " the archeopyle begins to develop by initial splitting along the margins of some of the reflected intercalary plates..." "One or more intercalary plate-areas separate from each other and from the cyst, leaving the cyst otherwise intact. Further splitting results in the progressive loss of the remaining intercalary plate-areas, the apex as a unit, the anterior ventral and anterior sulcal plates. The order of these events has not yet been definitely determined, but it seems likely that the apex and the sulcal plates are the last to detach " (Harland et al., 1975:851). This is also observable from the other early genera such as Sierdrupiella Bujak and Fisher 1976, Heibergella Bujak and Fisher 1976, Dapcodinium Evitt 1961, and Suessia Morbey 1975. The mid-dorsal keystone position always marks the initial archeopyle formation. We refer to this particular type of archeopyle formation as a disintegration archeopvle (see also Figs. 19, 20, 22, 23).

\section{Plate Series and Plate Designations}

Earliest dinoflagellate cysts differ from their later derivatives in that they have more plate series and more plates in a series. The Kofoid (1909) system of plate designation is not applicable to the early forms, leading to the usage of auxiliary terms such as "apical closing plates" (e.g. Wiggins, 1973), "anterior pre-cingular plates", and "pre-antapical plates" (Morbey, 1975). The evolutionary trend from early dinoflagellates to the modern genera, such as Gomyaulax and Peridinium, represents a basic reduction in the number of plates and plate series. This reduction can be accomplished in (wo ways (Fig. 1): 1) by fusion of several plates into a compound piece, later representing a single plate; and 2) by growth of a particular plate at the expense of other neighbouring plates. We have found evidence that both processes occurred during evolution, even though the first appears more prevalent.

In the Kofoid system plates with identical designations on two different cysts are not necessarily homologous. The loss of a plate in a series is not indicated as the Kofoid designation of that plate is not lost but becomes a designation for the next higher numbered plate of that series: e.g., if plate $1^{\prime \prime}$ is reduced to the point where it is lost, plate 2 " would assume the designation 1". All that would be recognized is a reduction of the number of plates in the precingular series by one. Similarly, if plates $2 a$ and 3a were fused into one plate, the Kofoid system would designate the new plate as $2 \mathrm{a}$ with the $1 \mathrm{a}$ or with the $3 \mathrm{a}$ plate. It is difficult to identify these changes except as a
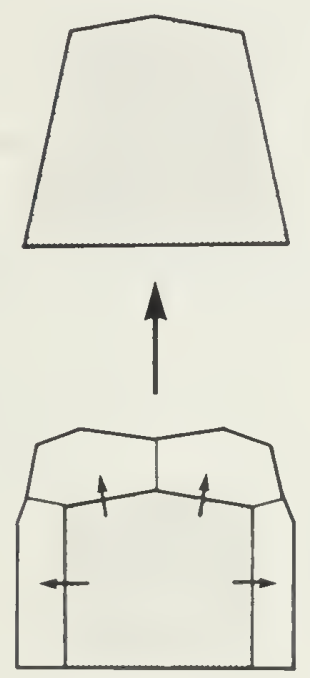

UNIDIRECTIONAL

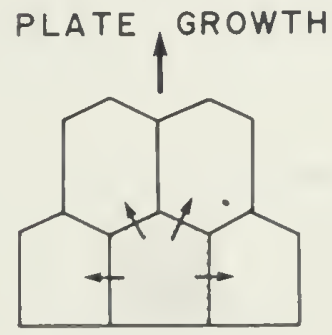

ADVANCED

TABULATION

PRIMITIVE

(suessioid)

TABULATION

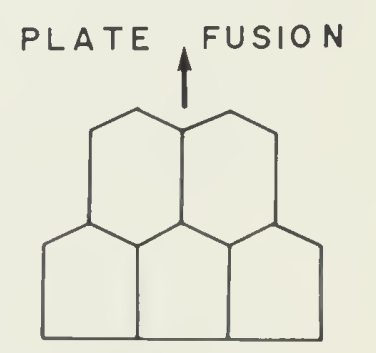

Fig. I Reduction of plate numbers from primutive to advanced cyst types. 
reduction in the number of plates in that series or as rudimentary sutural traces on the fused plate.

The loss of a series of plates is an even more distinct change. If cysts similar to those of Suessia lost a series of plates, the series above or below would then take the place in designation of the lost series in the Kofoid system. For example, if the precingular series was reduced or fused with the cingular series, the anterior precingular series (Morbey, 1975) would then become the precingular series. The use of the Kofoid system, therefore, demands a change in designation of plates and plate series as reduction and/or fusion occurs. In lieu of a better system we will employ the Kofoid system during our discussion of evolutionary trends, but we alter designations of plates and plate series. For a better understanding of cyst evolution it will ultimately be necessary to employ a terminology based on homologous entities.

\section{Terminology}

We use descriptive terms as outlined in Williams et al,, (1973). Evitt et al. (1976) proposed several alterations and several new terms that Norris (1978a) has criticized, in particular the introduction "of the term paraplate and numerous derivates with the prefix para-" as complicating the terminology. We agree with this criticism, because most thecal and cyst morphological features are controlled genetically (Norris, 1978a). Furthermore, the prefix "para-" not only has the meaning " near, beside" but also implies "inferior".

The confusing term "proximochorate" had been used to describe well-developed ornament on proximate cysts in addition to that in the reduced chorate type as in Spiniferites Mantell (emend. Sarjeant 1970). Norris (1978a) has termed the latter type "spiniferate," i.e. outward ornament of reduced length, developed around a spherical main body. We use the term "apteate" for ornament, which is developed on a proximate cyst, but does not reach any great length. Apteate ornament is typically found in Aptea, Psendoceratium, Cyclonephelium, and Gochteodinia.

The term omphalos (from Greek omphalos, naval) is here proposed for the irregular subcircular to variably shaped thickening, which is often found ventrally at or near the apical end of the sulcus within the cyst body. The omphalos probably developed out of the accumulation body (eyespot, PAS-body) of the living dinoflagellate. In Wolosiniskia coronata, the accumulation body consists "of a large number of pigment-containing lipid globules, which lie immediately beneath the theca in the vicinity of the sulcus" and "is situated adjacent to a flagellum" (Crawford and Dodge, 1971:702-703). Schmitter (1971) also observed the PAS-bodies of Gonyaulax polyedra beneath the upper part of the sulcus. The eyespot occurs in motile and encysted living dinoflagellates. It may or may not be bounded by an envelope, which explains its variable shape and in $W$. coronata the eyespot remains in the cell, when the cytoplasm is extruded (Crawford and Dodge, 1971), a fact which could account for its preservation in fossil cysts. The function of the eyespot might be related to accumulation of waste products or digestion (Bibby and Dodge, 1972). The omphalos generally stains extremely well (as the eyespot; Schmitter, 1971). Its formation might be related to the presence of carotins in the eyespot since sporopollenin-like compounds are polymerized esters of carotins (Brooks et al., 1971). However, this possible relationship requires further investigation.

In our study the omphalos is valuable in rapidly locating the ventral area of a cyst, especially in Pseudoceratiaceae and Rhaetogonyaulacaceae.

\section{Materials and Methods}

The Canadian samples contributed by Davies are part of the material used in his $\mathrm{Ph} . \mathrm{D}$. thesis on the palynostratigraphy of the Sverdrup Basin, District of Franklin (Davies, 1979) under the supervision of Dr. G. Norris (Department of Geology, University of Toronto). See Fig. 2. Material from the German Lower Saxony Basin was obtained by Dörhöfer as part of a post-doctoral research programme at the University of Toronto on Lower Cretaceous Palynostratigraphy. Localities and ages are given on Figs. 2 and 3.

Light microscopy was done with the Leitz Orhoplan microscope no. 715326 in the Department of Geology, University of Toronto, using both interference contrast and bright field optics. All figures are accompanied by original sample numbers (e.g. W1 1410a or KBT $10 / 39.5 / 3)$, Royal Ontario Museum collection numbers (e.g. ROM 36409), and the stage coordinates (e.g. $49.8 / 100.3$ ) of the above microscope; the upper righthand corner of the slides corresponds to stage reading $0.0 / 90.0$. The material is housed in the Royal Ontario Museum. Scanning electron microscopy was done with a Cambridge Stereoscan Mark 2a, at $20 \mathrm{kV}$ electron gun potential. The specimens were coated with gold or with carbon and gold in a high vacuum unit following the gas evaporation method. The specimens are single mounted on small photographic film squares, which in turn are mounted in groups of four to eight on stubs. The stubs have received ROM collection numbers. Individual specimens can be located by counting clockwise on the stub starting from a small notch on the periphery. 


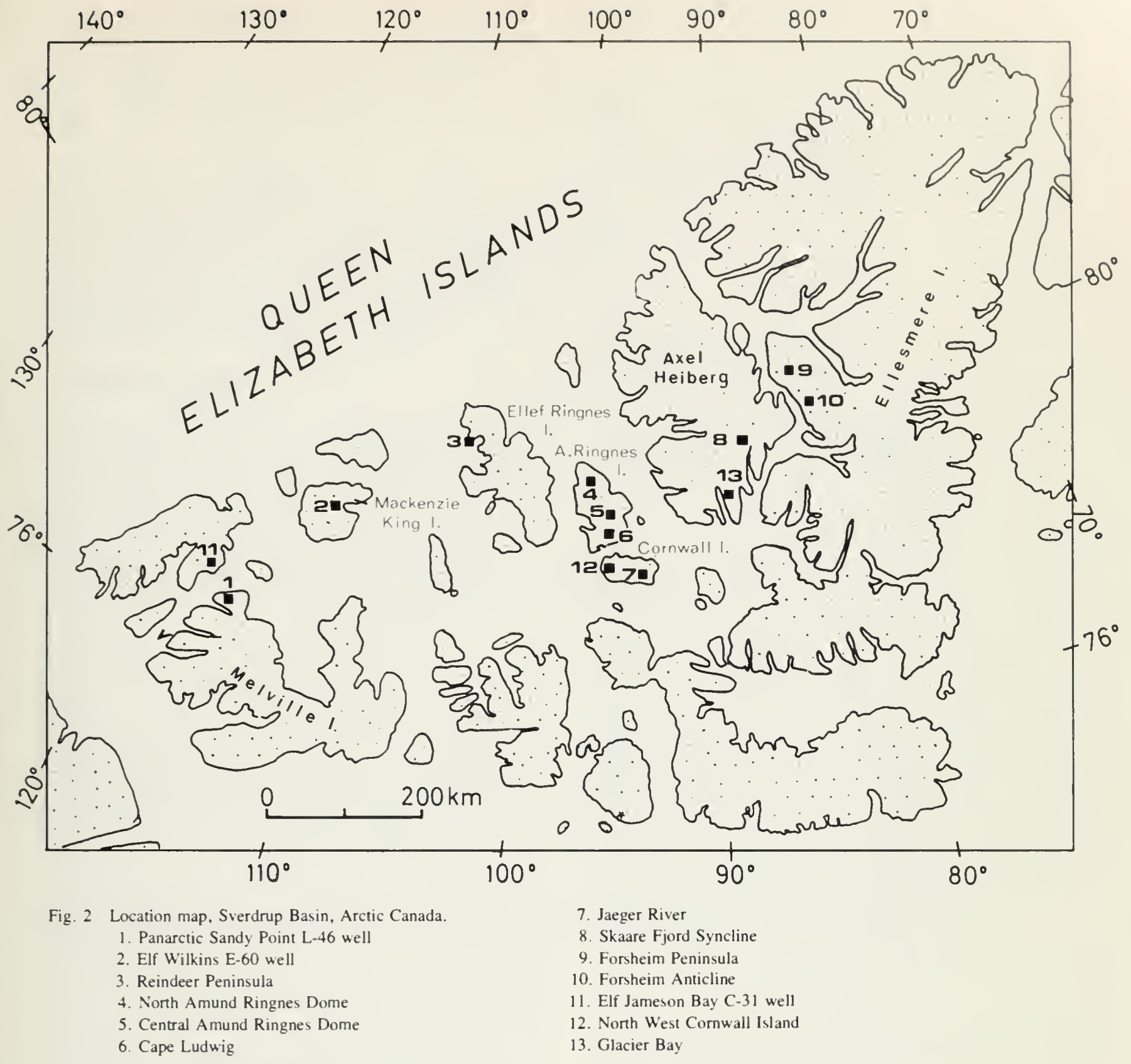

Stratigraphic Review of Cyst Characters of Pertinent Genera

This review follows a lineage of progressive evolution of important cyst characters such as tabulation and archeopyle. Although this section is descriptive, the concepts of plate fusion, plate reduction, imbrication, and the resulting stable mid-dorsal keystone position outlined above should be kept in mind.

The review is in four sections that correspond with the four families of dinoflagellate cysts in Suborder Rhactogonyaulacineae. These sections are discussed in ascending stratigraphic order: Rhaetogonyaulacaceae (Triassic-Lower Jurassic), Phallocystaceae (LowerMiddle Jurassic), Pareodiniaceae (Middle Jurassic-Lower Cretaceous), and Pseudoceratiaceae (Upper JurassicLower Cretaceous). 


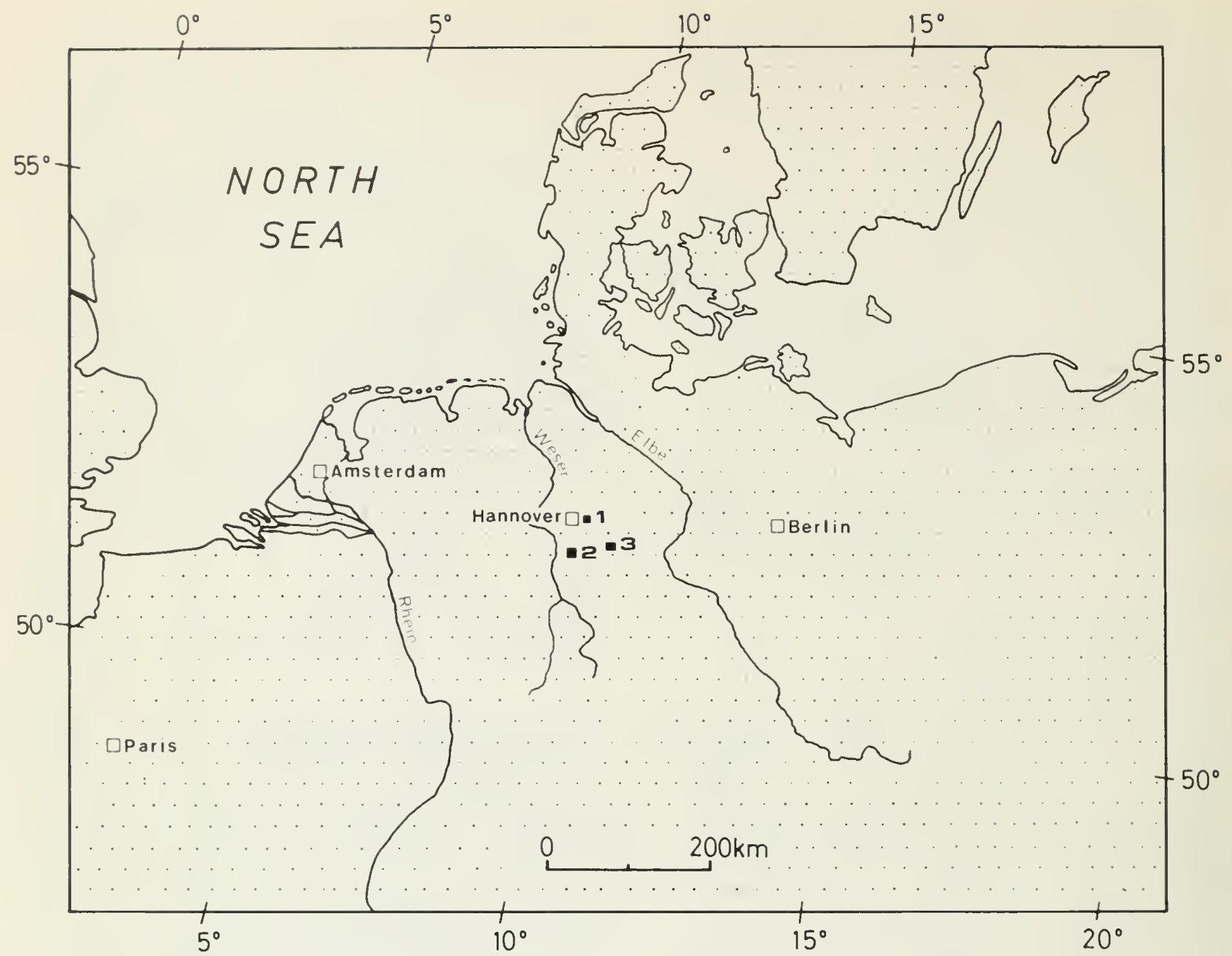

Fig. 3 Localion map, northwest Germany.

1. KBT-wells, Peine, Aptian

2. KTH-wells, Hils embaymenl, Valanginian-Haulerivian localily Gehrden (Barremian) halfway belween locality 2 and Hannover.

3. Salzgiller. Albian

\section{Triassic-Lower Jurassic Dinoflagellates}

Boreal Triassic marine algal cysts show distinctive dinoflagellate characters, namely specific tabulation patterns, distinctive modes of archeopyle formation, and cingular and sulcal furrows. These earliest dinoflagellate cysts are unique in their suessioid character (Norris, $1978 \mathrm{a}, \mathrm{b})$, that is having more plates and series than later dinotlagellates. This feature is considered primitive. The principal genera are reviewed below.

\section{Suessia Morbey 1975}

Suessia was erected to accommodate cysts with an unusually high number of plates and series according to the following tabulation formula '"? ', $n$ a, $n$ ap, $n^{\prime \prime}, n$ c, $n^{\prime \prime}$ ', n p, n pa, 1" ", n s. n may be up to 14 and the total number of plates may be over 60 . "ap" and "pa" are the postapical and the preantapical series respectively. Suessia is the only dinoflagellate cyst genus known to have nine series. The earliest occurrences are in the Middle Norian (Wiggins, 1976). The archeopyle is of the disintegration type (Figs. 22E, F, 23A, C, D, F).

\section{Rhaetogonyaulax Sarjeant emend. Harland et al., 1975}

Two species of Rhaetogonyulax were first recorded from Britain (Sarjeant, 1963) both having spindle-shaped cysts. The archeopyle formation occurred by a progressive loss of plates in the mid-dorsal epitractal area (Sarjeant, 1963; Harland et al., 1975) initiating at the intercalary plates (disintegration archeopyle). The tabulation formula, as revised by Harland et al. (1975), is 4-?6', 5-?6a, lav, 7"', $7 \mathrm{c}, 7^{\prime \prime \prime}, 1 \mathrm{p}, 1 \mathrm{pv}, 3 \mathrm{~s}, 3^{\prime \prime} \prime \prime$. The precingular series is 
narrow in width. Shublikodinium Wiggins 1973 also has a disintegration archeopyle, an almost identical tabulation formula and a spindle shape. We follow Stover and Evitt (1978) in that the two genera are synonymous, with Shublikodinium junior to Rhue'logontoulax.

\section{Heibergella Bujak and Fisher 1976}

Heibergella was erected to accommodate untabulated, single walled cysts with an I-3I archeopyle. The type species, H. astmmetrica Bujak and Fisher (1976), however, appears to exhibit sutural ornament.

\section{Dapcodinium Evitt 1961}

Dapcodinium was reported from the Rhaetian to Sinemurian by Wiggins (1976), but ranges further into the Toarcian and Bajocian where it has been found in association with Phallorysta nov. gen., Comparodinium Morbey emend. Wille and Gocht (in press) and Susadinium gen. nov. It retains suessioid characters and the disintegration archeopyle. The tabulation formula is: $4^{\prime}, 4 a, 7^{\prime \prime}, 6 c, 66^{\prime \prime}, 2 p, 1^{\prime \prime \prime \prime}$ (Evitt, 1961).

\section{Sverdrupiella Bujak and Fisher 1976}

Sierdrupiella closely resembles Rhaetogomaulax and Heibergella, but is defined as cavate. Bujak and Fisher (1976) have already demonstrated the wide variability within the genus, especially regarding archeopyle formation and the degree of endoblast contraction. The latter is the sole difference between Heibergella and Sierdrupiella and, in view of the variability, appears a questionable generic criterion. All specimens we have investigated (Figs. 19, 20) possess a distinct disintegration archeopyle, initiating mid-dorsally between the apical and intercalary plate series. This corresponds to the second most preferred position with respect to the imbrication scheme. The pronounced cingular ornament suggests strong adcingular lap-joints. The ornament (spines, baculae, etc.) is not randomly distributed but is penitabular. The tabulation has not been determined in detail, but four series (including a narrow protoprecingular one) can be recognized on the epitract (Fig. 20C-E). In general the tabulation appears complex and similar to that of Rhaelogomanlax.

\section{Noricysta Bujak and Fisher 1976 emend.}

Noricysta appears as early as the Early Norian, Bujak and Fisher (1976). It is cavate with an (AI) archeopyle and crests developed apically and antapically. It was described as untabulated. However, topotype material has yielded specimens with clear tabulation defined by sutural crests interpreted originally as folds (Figs. 24A-C, 22A, B, $21 \mathrm{D}-\mathrm{G})$. The tabulation formula is $6^{\prime}, 8 \mathrm{a}, 10^{\prime \prime}, 9 \mathrm{c}, 10^{\prime \prime}$ ', $6 p, 6 " \prime$, ?s.

\section{Hebecysta Bujak and Fisher 1976}

Hebecysta is the earliest dinoflagellate cyst known in which the archeopyle involves only three intercalary plates. The tabulation is not well known but includes at least three intercalary and four apical plates. It differs from Glomodinium Dodekova 1975 by its cavate nature. The precingular series is not as narrow as in Rhorelogonyuulax. Hebecisla occurs with Sierdrupiella in the early Late Norian.

\section{Late Early Jurassic and Early Middle Jurassic Dinoflagellates}

Reports on dinoflagellate cysts from the late Early Jurassic are rare. Except for the widespread occurrences of Nannoceratopsis Deflandre 1938, only the "Maturodinium" "assemblage from the German Lias (Morgenroth, 1970) has been recorded.

The high northern latitudes (Sverdrup Basin) have produced the new genera Phallorysia, Susadinium, and Dodekovia in which several important morphological features are developed that distinguish this complex from earlier dinoflagellates. Archeopyle types include $(A I)+P,(A)+I$ and $I$. The number of intercalary plates is four or five, and the apical plate number is usually four. The epitractal plate series are reduced to three. Some genera have a shape similar to pareodiniacean cysts.

\section{Comparodinium Morbey 1975}

Comparodinium has a $2 \mathrm{~A}_{3,4}$ archeopyle, as recently demonstrated by Wille and Gocht (in press). Its tabulation is $5^{\prime}, 5-6 \mathrm{a}, x^{\prime \prime}, x c, x^{\prime \prime}$ ', 5p, $1 \mathrm{pv}, \mathrm{l}^{\prime \prime}$ "'. The archeopyle is unusual and the suessioid tabulation indicates relationship with primitive genera.

\section{Dodekovia gen. nov.}

Dodekovia has a complex $3 \mathrm{I}_{2-4} 3 \mathrm{P}_{4-6}$ archeopyle, which in overall shape resembles later gonyaulacean P-types. Yet, archeopyle development (Fig. 23B, E, H) in separate opercular pieces resembles earlier disintegration modes. The tabulation is $4^{\prime}, 5 \mathrm{a}, 9^{\prime \prime}, 8 \mathrm{c}, 9^{\prime \prime} \prime, 2 \mathrm{p}, 2^{\prime \prime} \prime \prime, 4 \mathrm{~s}$.

\section{Phallocysta gen. nov.}

Phallorysta has an elongated intercalary archeopyle consisting of three plates; the central intercalary is larger than the two flanking plates. The epitract is thin and of variable length, while the hypotract is thickened. The tabulation formula is $4^{\prime}, 5 \mathrm{a}, 6^{\prime \prime}, ? 6 \mathrm{c}$, '? $6^{\prime \prime}$ ', ?" "'. 
Susadinium gen. nov.

Susadinium has low protuberances in presumably intratabular position. Archeopyle formation occurs through the loss of three dorsal intercalary plates. The tabulation formula is 4?', 5a, ?6"', ?c, 5' ', ?1"' '". The development of protuberances in the post-and precingular series is greater on the distal side, leaving a large sulcus.

\section{Pareodiniacean Cysts (Middle Jurassic-Lower Cretaceous)}

Following Norris's (1978b) emended diagnosis for the family Pareodiniaceae, we regard these features as diagnostic (except number 5):

1. Elongated proximate cyst body with an apical horn and infrequently one or two antapical horns.

2. One to three anterior intercalary plates.

3. Intercalary archeopyle with a transinistral 2 a plate.

4. Geniculate (A-shaped) precingular-intercalary boundary.

5. Tabulation traces present or absent.

The pareodiniacean cysts developed in the BajocianAalenian, possibly Toarcian (Sarjeant, 1975). Earliest records are by Herngreen and De Boer (1974) and Johnson and Hills (1973). Diversification accelerated in the Callovian-Upper Jurassic and declined in the Lower Cretaceous. Relevant genera are discussed below.

\section{Pareodinia Deflandre 1947}

Pareodinia consists of elongate (tear-drop) shaped cysts with 2I archeopyles. The ornament is low. The tabulation when evident is $4^{\prime}, 2 \mathrm{a}, 6^{\prime \prime}, ? 6 \mathrm{c}, ? 6-7^{\prime \prime} \prime, 1 \mathrm{p}, \mathrm{l}^{\prime \prime}$ '”, 3s. The age ranges from Bajocian to Albian.

\section{Glomodinium Dodekova 1975}

Cysts with a 3I archeopyle should be kept apart from Pareodinia. Following Dodekova (1975) we agree with the erection of Glomodinium for such cysts and thus reject the emendations of Pareodinia by Johnson and Hills (1973) and by Wiggins (1975).

\section{Paragonyaulacysı Johnson and Hills 1973 emend.}

The genus Paragonyaulacysta was erected for forms from the Callovian of the Canadian Arctic which exhibit gonyaulaceanlike tabulation but differ by the presence of intercalary plates and an intercalary archeopyle (2l after Johnson and Hills 1973). Reinvestigation of the type species $P$. calloviensis Johnson and Hills 1973 has revealed a 31 archeopyle and the following tabulation formula: $4^{\prime}, 3 a, 6^{\prime \prime}, 6 c, 6^{\prime \prime} \prime, 2 p, 1^{\prime \prime \prime}{ }^{\prime \prime}, 2 p v$.

\section{Komewuia Cookson and Eisenack 1960}

Komewuia has a 2I archeopyle and an apical and an antapical horn. The exact tabulation is not known. It ranges from Late Jurassic to Early Cretaceous.

\section{Netrelytron Sarjeant 1961}

Netrelytron was erected for pareodiniacean cysts with a contracted endoblast, antapical horn and calyptra. The mode of archeopyle formation according to the illustration (Sarjeant, 1976:pl. 4, figs. 3, 5) is intercalary. Wiggins (1975) regarded the endoblasts of Netrelytron as "optical artifacts resulting from folding of the phragma" (Sarjeant, 1976:15). Sarjeant (1976), however, maintained the presence of a distinct endoblast.

\section{Gochteodinia Norris 1978b}

This genus was erected to separate spinose apteate forms with a 2I intercalary archaeopyle shown in Figs. 33F, G, 34G, and Evitt (1967: pl. 4, figs. 1-6), from Pareodinia and from Imbatodinium Vozzhennikova 1967.

\section{Pseudoceratiacean Cysts (Upper Jurassic Lower Cretaceous)}

Wall and Evitt (1975) have drawn attention to similarities between Cretaceous pseudoceratiacean cyst genera such as Pseudoceratium, Muderongia, Odontochitina, Phoberocysta, Endoceratium, and Aptea on the one hand to modern Ceratium Schrank 1793 on the other. They have shown that all these genera exhibit at least some important ceratioid features. Their diagnostic criteria are summarized as: 1) presence of three or four coplanar horns, in apical, antapical, and postcingular position; 2) asymmetrical hypotract, the left side being longer; and 3) basic gonyaulacean tabulation pattern, that is $4^{\prime}, 0 a, 6^{\prime \prime}, 5-6 c$, 6"' $1 \mathrm{p}, \mathrm{l}^{\prime \prime \prime}$ ".

Features 1 and 2 are present from almost all the cited Cretaceous genera, but the tabulation could only be determined in few instances. Wall and Evitt (1975) furnished partial tabulation formulae for Pseudoceratium pelliferum Gocht 1957, Endoceratium ludbrooki (Cookson and Eisenack) Vozzhennikova 1965, and Muderongia cf. mcwhaei Cookson and Eisenack 1958. All the preceding are type species and, therefore, the ceratioid affinity of these three genera on the basis of the tabulation formula could be considered established. No tabulation formula could be determined in the remaining genera Phoberocysta, Odontochitina, and Aptea. Imbatodinium, however, was considered by Wall and Evitt (1975) as non-ceratioid, because both hypotractal horns are in antapical position with none in postcingular. Huber and Nipkow (1923) showed that the development of horns is 
sensitive to ecological factors inasmuch as small temperature variations can easily suppress or enhance the development of one or more horns. The absence of posstcingular horns, therefore, does not exclude ceratioid affinities.

Most pseudoceratiaceaen genera exhibit strong evidence for the possession of intercalary plates within the operculum. This character is very important in establishing the evolutionary ancestry of the Pseudoceratiaceae. The principal genera of this family are reviewed below, and then followed by discussions on the relevance of intercalary plates and horn position.

\section{Imbatodinium Vozzhennikova 1967}

The development of the generic concept of Imbatodinium is closely related to that of Broomea Cookson and Eisenack 1958, Necrobroomea Wiggins 1975, and Batioladinium Brideaux 1975. Broomea ramosa Cookson and Eisenack 1958 exhibits a clear intercalary archeopyle, formed by the loss of a single plate, probably corresponding to plate 2a (Wiggins, 1975; Brideaux, 1975). Alberti (1961) described six new species from the Valanginian to Late Barremian of northivest Germany, which he provisionally assigned to Broomea, but noted that their archeopyles were not formed by the loss of an intercalary plate, because it was apparent that "in some species an apical part of the shell is often lacking" (Alberti, $1961: 26$, translation by Dörhöfer). This was interpreted by subsequent authors as an (A) type archeopyle and, therefore, Brideaux (1975) followed Alberti's proposal and erected Batioladinium, to which he transferred most of Alberti's "Broomea" species. Wiggins (1975) formulated the genus Necrobroomea, not knowing of Batioladinium. Earlier, however, Vozzhennikova (1967) had described the genus Imbatodinium, which included species with intercalary and apical archeopyles. The type species, $I$. kondrajevi Vozzhennikova 1967 was stated to have an apical archeopyle, also apparent from her illustrations and reillustrated in our material (Figs. 27D, E, 28A, 29B, C). We investigated specimens of Imbatodinium kondratjevi Vozzhennikova 1967, "Broomea" jaegeri Alberti 1961, "Broomea" longicornuta Alberti 1961, "Broomea" micropoda Eisenack and Cookson 1960, and "Broomea" pellifera Alberti 1961. All species conform in general shape, tabulation, and archeopyle, and belong to $\mathrm{Im}$ batodinium, which has priority over Batioladinium and Necrobroomea. Well-preserved specimens of "Broomea" pellifera exhibited the tabulation $4^{\prime}, 2 \mathrm{a}, 6^{\prime \prime}, ? 6-7^{\prime \prime}$ ', ?1-2p, l" ", ?pv (Fig. 33A-D). The archeopyle is formed by the loss of a compound operculum including all apical and anterior intercalary plates $(4 \mathrm{~A} 21)$. In all the above species the hypotract is attenuated, resulting in a low position of the cingulum on the cyst body. Two hypotractal horns are always present.

\section{Aptea Eisenack 1958}

Aptea was erected as a monotypic genus, the type species being Aptca polymorpha Eisenack 1958. The sole difference from Pseudoceratium is the considerable reduction in horn length. Aptea rugulosa Clarke and Verdier 1967 was added to the genus but differs significantly from Aptea polymorpha, as it bears two symmetrically placed antapical horns on the hypotract. This is a feature of Comningia Cookson and Eisenack 1960 to which Aptea rugulosa has been transferred (Stover and Evitt, 1978). Davey and Verdier (1974) emended the genus, erected Aptea securigera and transferred $C y c$. lonephelium attadalicum Cookson and Eisenack 1962 and Cyclonephelium eisenackii Davey 1969 to the genus. In their emended generic diagnosis the following features were considered important: 1) asymmetrical roundedtriangular outline; 2) ornamentation with membranous crests and/or processes; and 3) indications of horn positions (apical, antapical, postcingular) by ornament and/or protuberances of the autophragm. They emphasized the typical asymmetry which serves to separate Aptea from Cyclonephelium Deflandre and Cookson 1955, Canningia Cookson and Eisenack 1960, and Tenua Eisenack 1958. It is apparent that the only difference between Aptea and Pseudoceratium is the greater length of horns in the latter genus. This feature is probably of subgeneric significance, but for the present Aptea is retained apart from Pseudoceratium.

Upper Aptian samples from northwest Germany contain abundant Aptea polymorpha. A detailed description and emendation of the species is given below in the systematic section. The most important features are the tabulation formula 4', 2a, 6"', 5-6c, 6"' ', Ip, I" '", ?3-6s and a (4A21) archeopyle. The same type of archeopyle was found in Imbatodinium indicating a close relationship between both genera.

\section{Pseudoceratium Gocht 1967}

The original generic diagnosis of Pseudoceratium (Gocht, 1957:166) did not mention many features which now could serve as differential criteria. In the diagnosis of the type species $P$. pelliferum Gocht 1957, however, the following criteria were considered important: 1) asymmetrical-triangular outline; 2) development of three horns (apical, antapical, right postcingular); and 3) ornamentation with short spines, which may fuse at the bases.

Tabulation could not be determined in any of Gocht's specimens and this feature was included in the generic diagnosis, where allowance was made to include $P$. ?nudum Gocht 1957: "shell smooth or clothed with short appendices" (transl.). Pseudoceratium ?nudum and P?. tetracanthum Gocht 1957 were only doubtfully included and the latter species was transferred to Muderongia (Alberti 1961: 14). At present $P$. ?nudum and $P$ 
dettmanniae Cookson and Hughes 1964 are the only smooth species included in Pseudoceratium. Psendoceratium dettmannicie is clearly cavate and, therefore, belongs to Endoceratium Vozzhennikova 1965 as suggested by Wall and Evitt (1975). Stover and Evitt (1978) recently made the transfer. Smooth asymmetrical forms with three horns are best kept in Odontochitina and, hence, $P$. ?nudum is transferred to this genus. After these transfers, only ornamented species stay in Pseudoceratium

Neale and Sarjeant (1962) encountered forms which exhibited some traces of tabulation but in all other respects conformed with the morphology of $P$. pelliferum. The presence of faint tabulation traces was considered sufficient to separate the tabulated species $P$. (Eopseudoceratium) gochiii Neale and Sarjeant 1962 (non Pocock 1962), who applied the same name to specimens of Imbatodinium jaegeri (Alberti 1961 comb. nov.) on subgeneric level. Eisenack (1961:284) had already discussed the irrelevance of such tabulation traces for classification purposes on forms which otherwise conform. For example he mentioned "Pseudoceratium" ludbrookiae, which was regarded as untabulated until specimens were found exhibiting clear tabulation. Hence, Eisenack (1964) rejected the subgeneric treatment of Pseudoceratium by Neale and Sarjeant (1962). Furthermore, he mentioned that in $P$. gochtii "the tabulation is at least hard to recognize" (translation by Dörhöfer: 325 ). It is interesting that the tabulation given by Neale and Sarjeant (1962) indicated the presence of an intercalary series. Wall and Evitt (1975) also observed specimens with tabulation traces from the same locality and called them $P$. pelliferum. They could not find support for the tabulation formula given by Neale and Sarjeant (1962) and rather suggested a basic ceratioid tabulation (without intercalaries). Davey (1974) and Duxbury (1977) also observed tabulated specimens of $P$. pelliferum but did not determine the tabulation formula. Singh's (1971: pl. 67, fig. 1) illustration of $P$. expolinum Brideaux 1971 suggests breakage along a suture between apical and intercalary plates. Specimens of $P$. pelliferum (Figs. 35F, 37B-E) also suggest the presence of two anterior intercalary plates, mainly based on the asymmetry of the archeopyle suture and a linear area devoid of ornament with a frequent indentation in the outline of the cyst in the area of the putative suture. Plate boundaries in Pseudoceratium are delineated by penitabular ornament. The tabulation appears identical to that of Aptea.

\section{Muderongia Cookson and Eisenack 1958, Phoberocysta Millioud 1969}

The following discussion of Muderongia is mainly based on specimens of Muderongia simplex Alberti 1961, which were encountered from Arctic Canada and Germany. Many folded specimens resembled cysts illustrated by Alberti (1961) as Cantulodinium Alberti 1961. This genus has only been found in Alberti's samples together with Muderongia simplex. From our material we suggest that Cantulodinium constitutes only folded Muderongia and we, therefore, consider it synonymous. The presence of two intercalary plates is demonstrated in Fig. 36C, D, F. The form of the archeopyle resembles that of Aptea, indicating close relationships between the two genera. Muderongia differs from all other pseudoceratiacean genera (except Phoberocista) in that it usually exhibits two almost bilaterally symmetrical postcingular horns and two antapical horns.

Muderongia is cavate and always smooth. This is the sole difference from Phoberocysta, which is always heavily ornamented (Millioud, 1969). In the position of horns, archeopyle suture and type, and cyst symmetry, this genus is very similar to Muderongia.

\section{Odontochitina Deflandre 1935}

No tabulation has yet been observed in this genus and to judge from the featureless surface, it is unlikely that detailed tabulation will ever be determined. The basic pseudoceratiacean appearance of Odontochitina has been noted by many authors, most recently by Wall and Evitt (1975). Several excellently preserved specimens from the German Neocomian have shown some possible traces of tabulation; yet, no formula can be fumished. The position of the sulcus is apparent from Fig. 40A. The body surface is covered by numerous pits which in some areas are densely aligned, probably representing tabulation sutures. The archeopyle suture is asymmetrical as in Aptea. Both genera appear to be closely related, suggesting similar tabulation.

\section{Tenua Eisenack 1958, Doidyx Sarjeant 1966 , Canningia Cookson and Eisenack 1960 , Cyclonephelium Deflandre and Cookson 1955}

Wall and Evitt (1975) discussed the possible relationship of these genera to the "Cretaceous ceratioid group". They cited several similarities between the two complexes including weak bilateral asymmetry, type (A) archeopyle, zigzag outline of archeopyle sutures and the offset of the sulcal notch to the left dorsal position. According to Wall and Evitt (1975) these genera lack three characteristics, which they consider typically ceratioid, namely, pronounced asymmetry of the hypotract, presence of postcingular horn(s), and Ceratium-type tabulation. On this basis they considered the entire complex non-ceratioid but closely related to the "true" ceratioids like Aptea and Endocercitium.

The type species of Temu (T. hystrix Eisenack 1958) is bilaterally symmetrical and has no indications of horns. It clearly exhibits dorsal and/or ventral reduction of its spine cover, similar to the reduction zones observable in Aptea and $C$ volonephelium. The archeopyle suture is also similar to the latter genus, as it does not exhibit the strong asymmetry of Aptea or Pseudoceratium. The tabulation 
has not yet been determined. The holotype specimen cannot be distinguished from Cyclonephelium. The only differences between Tenua hysrrix and Cyclonephelium distinctum Deflandre and Cookson 1955 are slightly longer and less densely arranged processes in the latter. Such a slight difference does not justify generic separation: hence, Teruse is a junior synonym of Cyclone phelium (Davey, in press) which, however, should be restricted to apteate cysts. Chorate cysts of this type were transferred to Glaphrocista Stover and Evitt (1978). Bilaterally symmetrical cysts with an uniformly dense cover of ornament, which subsequently were assigned to Tenua (in particular those from the Late Jurassic), are transferred to Batiacasphaera Drugg emend. Neither in $C$ yclonephelium nor in "Tenua" could the presence of an intercalary series be established.

The type species of Canningia (C. reticulata Cookson and Eisenack 1960) exhibits two pronounced antapical horns and two postcingular bulges. The former probably corresponds to plate positions $1 \mathrm{p}, \mathrm{l}$ " " (right) and 6" ', 1" "' (left) as shown by Wall and Evitt (1975) on Canninginopsis denticulata Cookson and Eisenack 1962, which is essentially similar to Canningia but with sutural ornament. It is not known whether an intercalary series is developed: however, some published illustrations would favour such an assumption, such as $C$. reticulata (Cookson and Eisenack 1960: pl. 38, fig. 2), C. colliveri (Cookson and Eisenack 1960: pl. 38, figs. 3, 4). From this evidence it seems that some Canningia have intercalary plates included in the operculum, resulting in the large archeopyle often observed. Canningia constitutes a heterogeneous group and further research is warranted.

The sole species of Doidyx (D. anaphrissa Sarjeant 1966) has three horns developed in apical, antapical, and right postcingular positions. The cyst body is clearly asymmetrical, the ornament is apteate, and the archeopyle suture is identical to that of Aptea. Doidyx anaphrissa, therefore, was transferred to Aptea (Sarjeant and Stover, 1978); its transfer to Tenua by Benedek $(1972: 9,10)$ was unwarranted. Within this complex clear intergradations are developed between the symmetrical group possessing intercalary plates and the symmetrical group without such plates. In the Late Barremian of Germany we have found cysts (Fig. 40B, F) with asymmetrical archeopyle sutures and slight asymmetrical body shape; only the apical horn is developed. The operculum contains intercalary plates. We regard these forms as extreme variants of Aptea anaphrissa.

\section{Intercalary Plates and Horn}

\section{Development in Pseudoceratiacean Cvsts}

Wall and Evitt (1975) regard forms as non-ceratioid if the hypotractal horns are situated antapically (instead of postcingularly) and the body is symmetrical. They stressed that the presence of intercalary plates would also indicate non-ceratioid aftinities. These points are discussed below.

\section{Intercalary Plates}

As demonstrated above, Imbatodinium and Aptea possess intercalary plates. These plates are part of the operculum. The typical asymmetrical pseudoceratiacean suture apparent from Canningia, Muderongia, Phoberocysta, Odontochitina, Pseudoceratium, and Endoceratium suggests the same for these genera. Few of them exhibit any tabulation and only with the use of interference contrast microscopy and SEM was it possible to detect intercalary/apical sutures. Affinities among the pseudoceratiacean taxa are stronger than resemblances to modern Ceratium; therefore, all the Cretaceous genera referred to as ceratioid (Wall and Evitt, 1975) should be regarded as pseudoceratiacean. Ceratium apparently has lost all signs of ancestral intercalary plates.

\section{Horn Positions: Antapical versus Postcingular}

Wall and Evitt (1975) argued against the relationship between "true Cretaceous ceratioids" and the "Broomea-group". They consider the presence of postcingular horns as essentially ceratioid. We have plotted in a schematic manner the position and development of horns in the entire pseudoceratiacean complex (Fig. 4). It shows that the earliest forms first developed two short antapical horns (Imbatodinium pelliferum, I. gochrii) which then became longer (Imbalodinium longicornutum Alberti, comb. nov.). Next was the development of two postcingular horns in addition to the two antapical horns. At the same time the right antapical horn was already reduced (Muderongia, Phoberocysta). Further evolution led to the loss of the left postcingular and right antapical horn (Odontochitina, Pseudoceratium, Aptea). All horns are further reduced in Aptea, connecting the genus to forms devoid of horns (Cyclonephelium) or only showing slight bulges (Canningia).

In the earliest forms (Imbatodinium) the cingulum is situated in the posterior half rather than centrally. Thus, the areas of origin of the antapical and the postcingular horns are close to each other. The pseudoceratiacean genera appear to have at least the potential ability to develop all five horns (Fig. 4, as shown in Canningia, Muderongia, or Phoberocysta). Specimens of Glomodinium from the Oxfordian/Kimmeridgian already exhibit a bulge in addition to the pronounced (?left) antapical horn (Fig. 29A), which might be interpreted as an incipient right antapical horn. Symmetry of pseudoceratiacean cysts is mainly expressed by the position of horns and the position of the anterior intercalary plates. Strong asymmetry, as a result of reduction of the right antapical horn, is always accompanied by a strongly asymmetrical archeopyle suture 


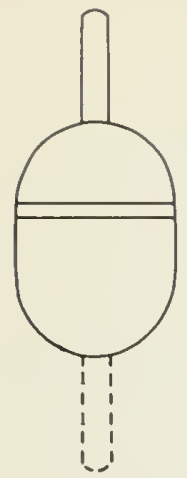

Pareodinia Komewuia
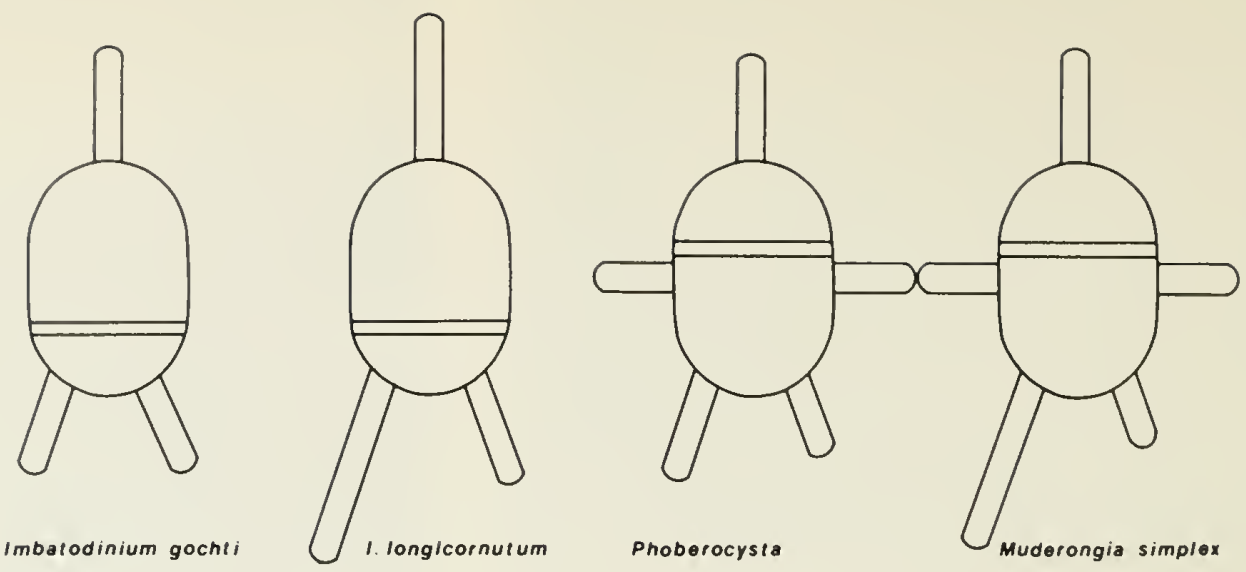
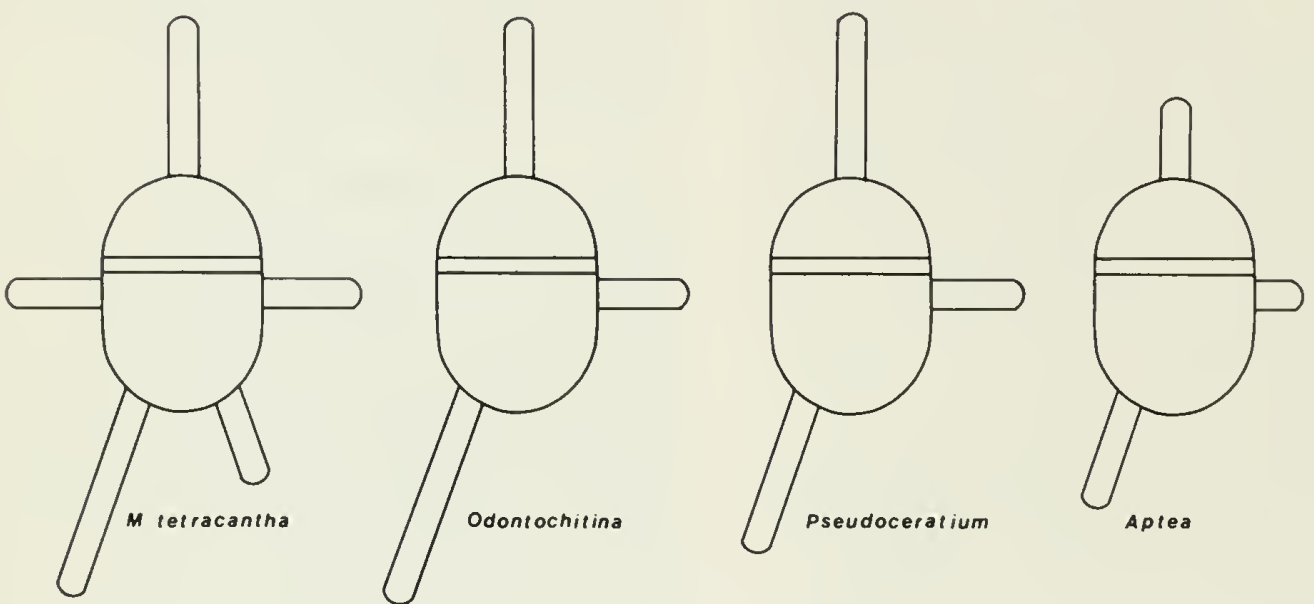

Fig. 4 Horn development of pseudoceratiacean cysts from pareodiniacean cysts (dorsal view).

inherent from a right-lateral shift of the intercalary plate position from the mid-dorsal area (Fig. 5).

Typical asymmetrical genera are Odontochitina, Pseudoceratium, Aptea, Endoceratium. Earlier forms such as Imbatodinium, Muderongia simplex, and Phoberocysta, which are more symmetrical with regard to the horn development and position, also have the intercalary plates placed centrally in mid-dorsal position. The proposed lineage (Fig. 7) constitutes a gradual development of closely related morphological cyst types.

In their experimental work on Ceratium hirundinella Huber and Nipkow (1923) have demonstrated that the angle of hypotractal divergence (between the right postcingular horn and the left antapical one) is positively related to water temperature. This angle increases with increasing temperature and decreases with decreasing water temperature. Also two-horned specimens developed in cold water, four-horned varieties in warm water. The earliest pseudoceratiacean forms have few horns and also have a very small spreading angle. This feature has been related to their possible derivation from high latitudinal cool-water areas (Dörhöfer, in press). The evolution of forms with more horns and a larger spreading angle was possibly related to the shift of cool-water masses into somewhat lower (and warmer) latitudes shortly after the beginning of the Cretaceous, for example Muderongia, Phoberocysta.

\section{Discussion (Figs. 6, 7)}

The following discussion on the evolution of archeopyles and associated cyst characters is based on the premise that the keystone plate is a dominant structural feature and has remained in mid-dorsal position.

The earliest dinoflagellates with undoubted tabulation have been recorded from the Late Triassic of Alaska and Arctic Canada (Wiggins, 1976, 1973; Fisher and Bujak, 1975; Bujak and Fisher, 1976). The Arctic Islands were shifted considerably northward during the Triassic and 


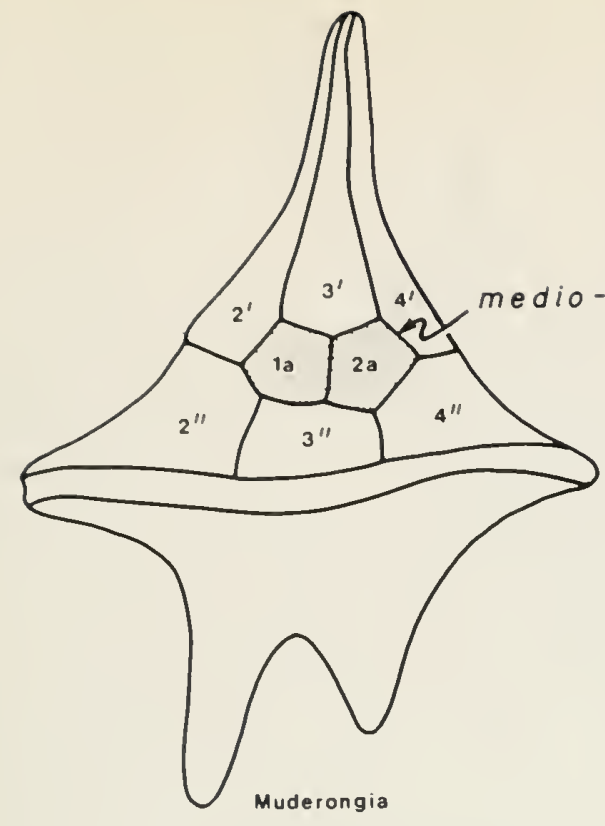

symmetrical

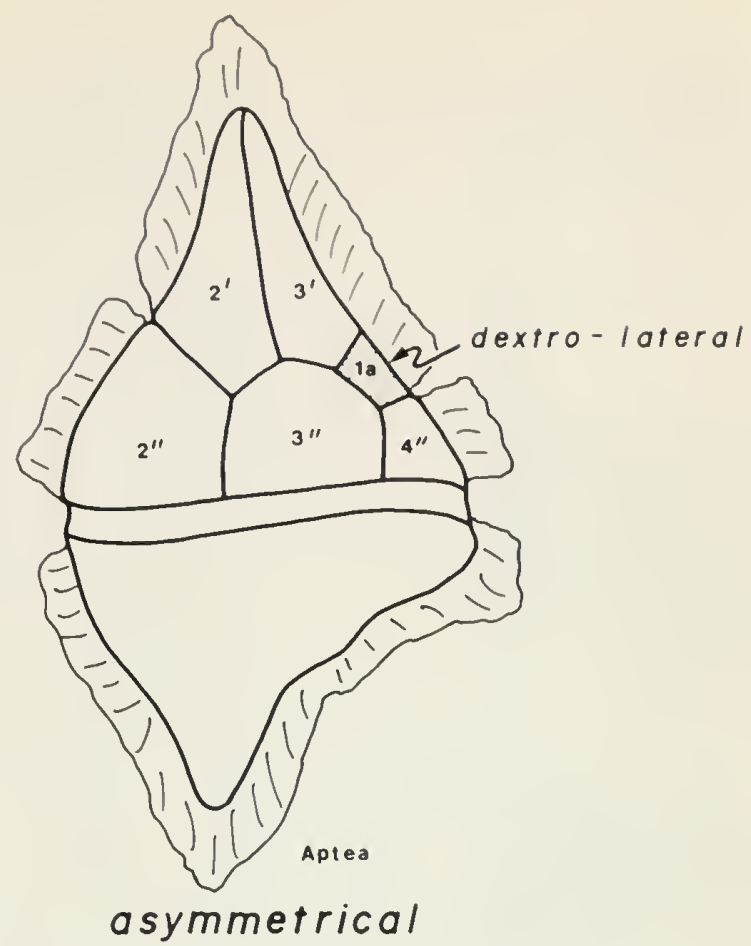

asymmetrical

Fig. 5 Relationship between bilaleral symmetry and position of anterior inlercalary plates in pseudoceraliacean cysls. Archeopyle (AI).

Early Jurassic (Irving, 1974) causing geographic isolation of the Arctic Basin. Rising continentality in high latitudes is of prime importance for influencing world climate (Donn and Shaw, 1977). A pronounced increase in surface albedo due to increased continentality at high latitudes would result, causing cooler boreal climates. Thermal and geographical isolation of the Arctic Basin would have been the ideal situation for the development of dinoflagellate cysts. Earliest cysts are proximate, which is a typical cool-water feature (Dörhöfer, in press). Chorate acritarchs such as Micrhystridium Deflandre 1937 may have adapted to the stressed polar environment by development of a proximate cyst mode (Dörhöfer, 1977a, b). These acritarchs would be expected to have primitive dinoflagellate features such as suessioid tabulation and disintegration archeopyles. Such forms have been found in the Lower Jurassic (Fig. 21A, C). Further research on Triassic acritarchs is needed to demonstrate dinoflagellate cyst ancestry.

Development of the ancestral dinoflagellate cyst stock probably occurred in the Late Triassic (latest Karnian; Wiggins, 1976) with Rhaetogonyulax as the earliest known member (Figs. 4, 5). The Rhaetogonvaulaxcomplex arose during the Late Triassic from earliest forms with rounded apex and antapex ("Shublikodinium") to more spindle-shaped forms like $R$. rhaetica (Sarjeant) Loeblich and Loeblich 1968. However, the basic form was maintained. Complex and strongly tabulated cysts with rounded body shape such as Suessia and its cavate counterpart Noricysta appear near the base of the Norian
(Wiggins, 1976) and probably are directly related to the "Shublikodinium" types of Rhuetogonyaulax.

Sverdrupiella and Heibergella also evolved directly from Rhaelogonyaulax in the Late Norian, maintaining the typical spindle shape and the primitive disintegration archeopyle, initiated by the loss of one to three anterior intercalary plates (Fig. 20D). Neither Rhaetogonyaulax nor Sierdrupiella have been recorded from sediments younger than Hettangian; however, genera that are very similar in shape, structure, and ornament such as Wanaea Cookson and Eisenack 1958 and Glossodinium loannides et al. 1977 occur in the Late Jurassic. Dapcodinium from the late Hettangian of Denmark (Evitt, 1961) and the late Pliensbachian of northwest Germany (Morgenroth, 1970) continued the primitive lineage. The disintegration archeopyle is maintained, but, increasing stabilization is indicated by the fact that the apical series constitutes one opercular piece and of ten remains attached ventrally (Figs. $25 \mathrm{E}, \mathrm{G}, 22 \mathrm{D}, \mathrm{G}, \mathrm{I})$. In tabulation there is a reduction of the number of plates. Specifically, the intercalaries are reduced to four or five.

Dapcodinium was observed in the Sverdrup Basin to range into the Toarcian to Bathonian.

Comparodinium appeared in the latest Rhaetian (Morbey, 1975) and has been found up into the Toarcian to Bajocian of Arctic Canada and Germany (Wille and Gocht, in press). It is the earliest genus with a stabilized archeopyle (apical). The tabulation indicates affinities with Dapcodinium.

The Toarcian is characterized by the first occurrence of 

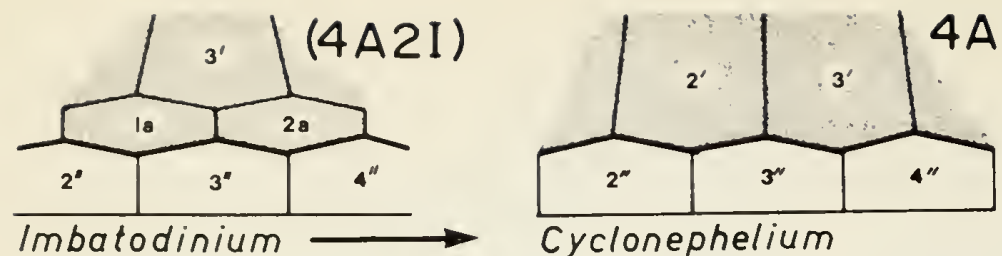

Cyclonephelium

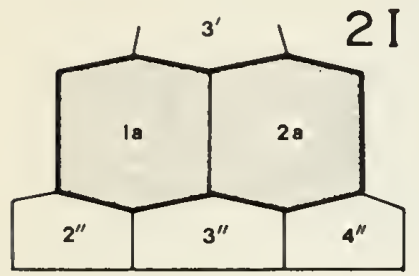

Pareodinia

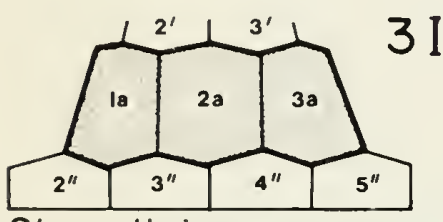

Glomodinium
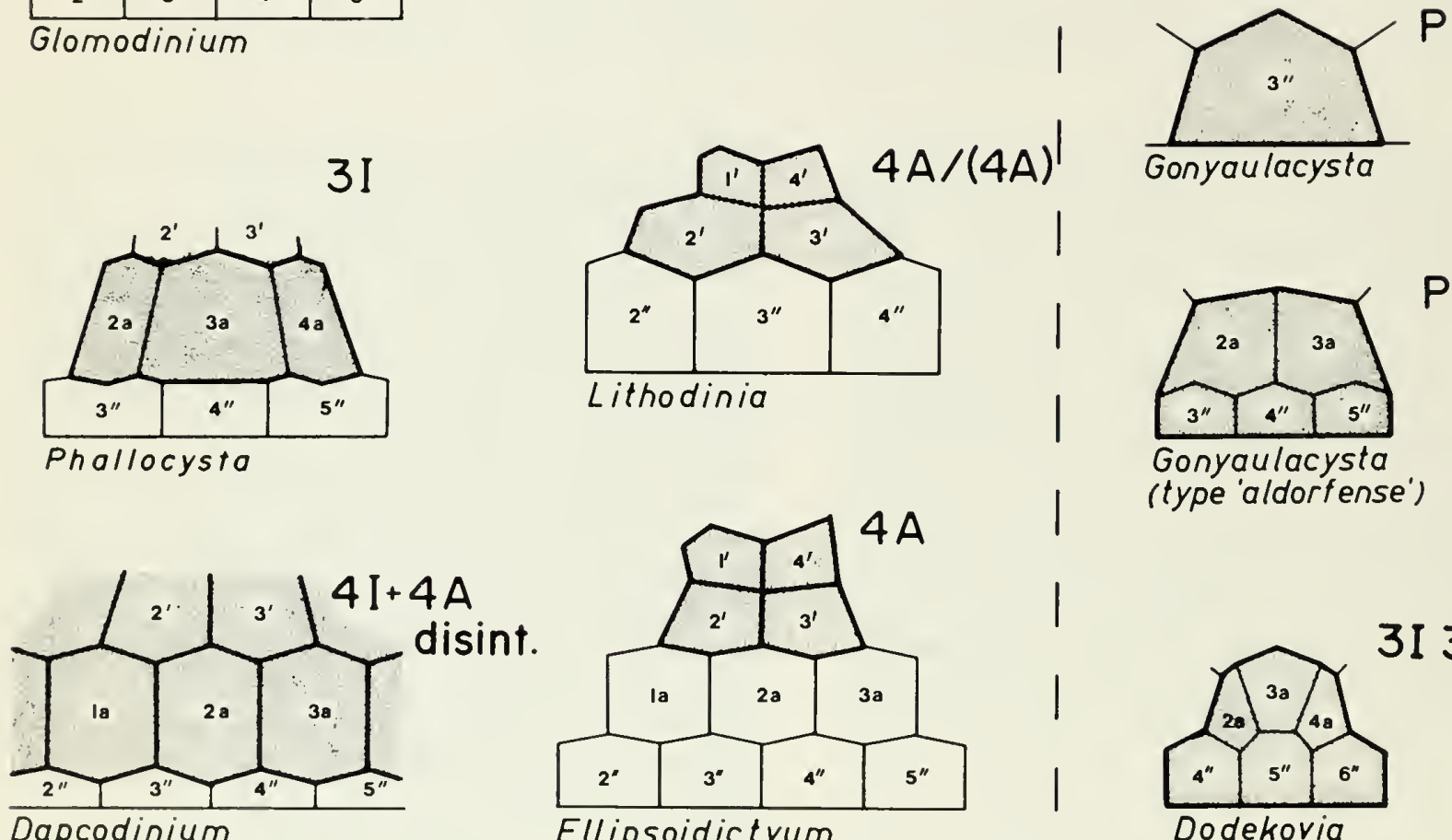

Phallocysta

\section{Ellipsoidictyum}
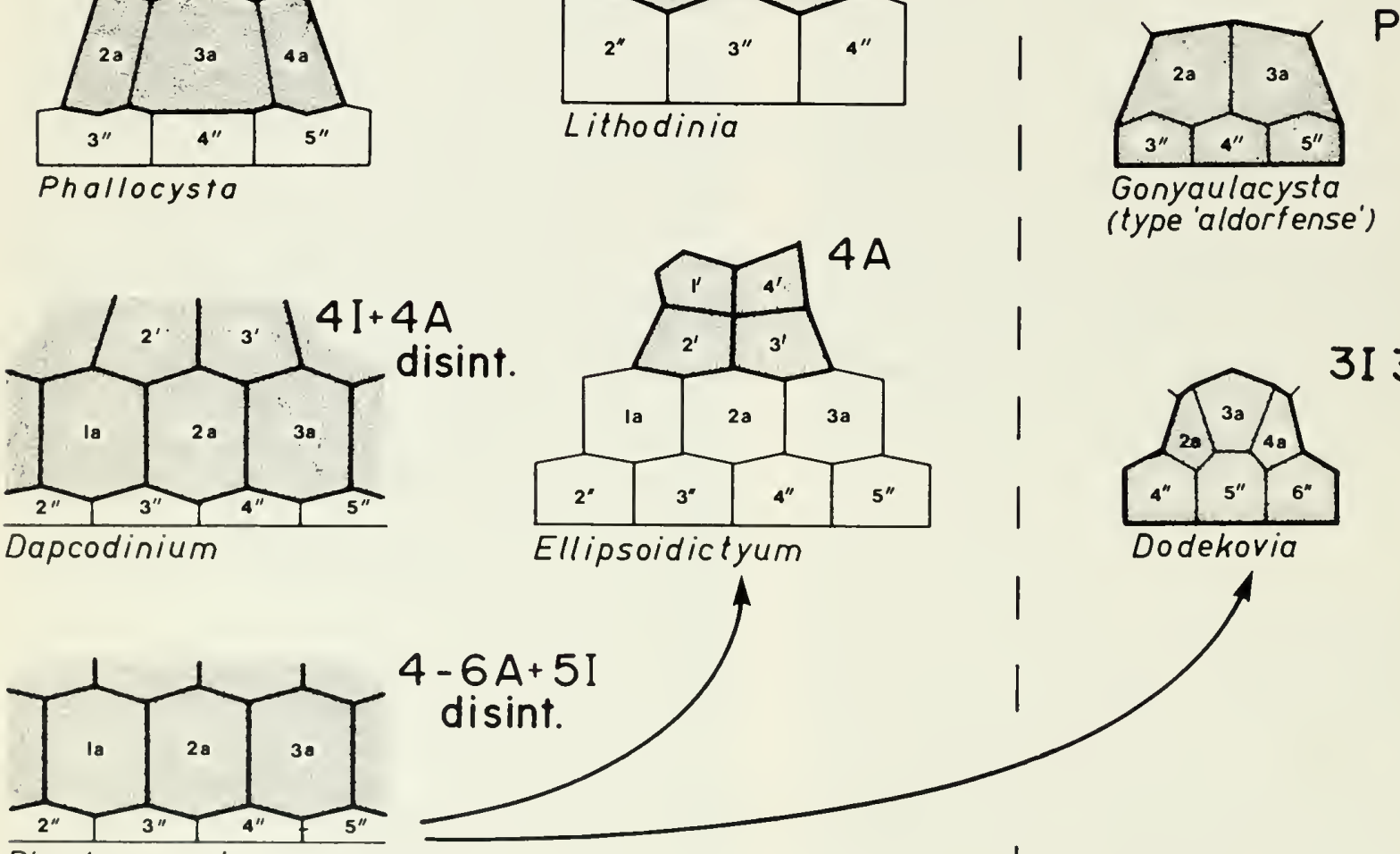

$4-6 A+5 I$ disint.

Rhaetogonyaulax

RHAETOGONYAULACINEAE HYSTRICHOSPHAERID

GONYAULACYST

Fig. 6 Evolution of archeopyle types within the Rhaetogonyaulacineae, Hystrichosphaeridiineae, and Gonyaulacystineae from a common ancestor with disintegration archeopyle. 


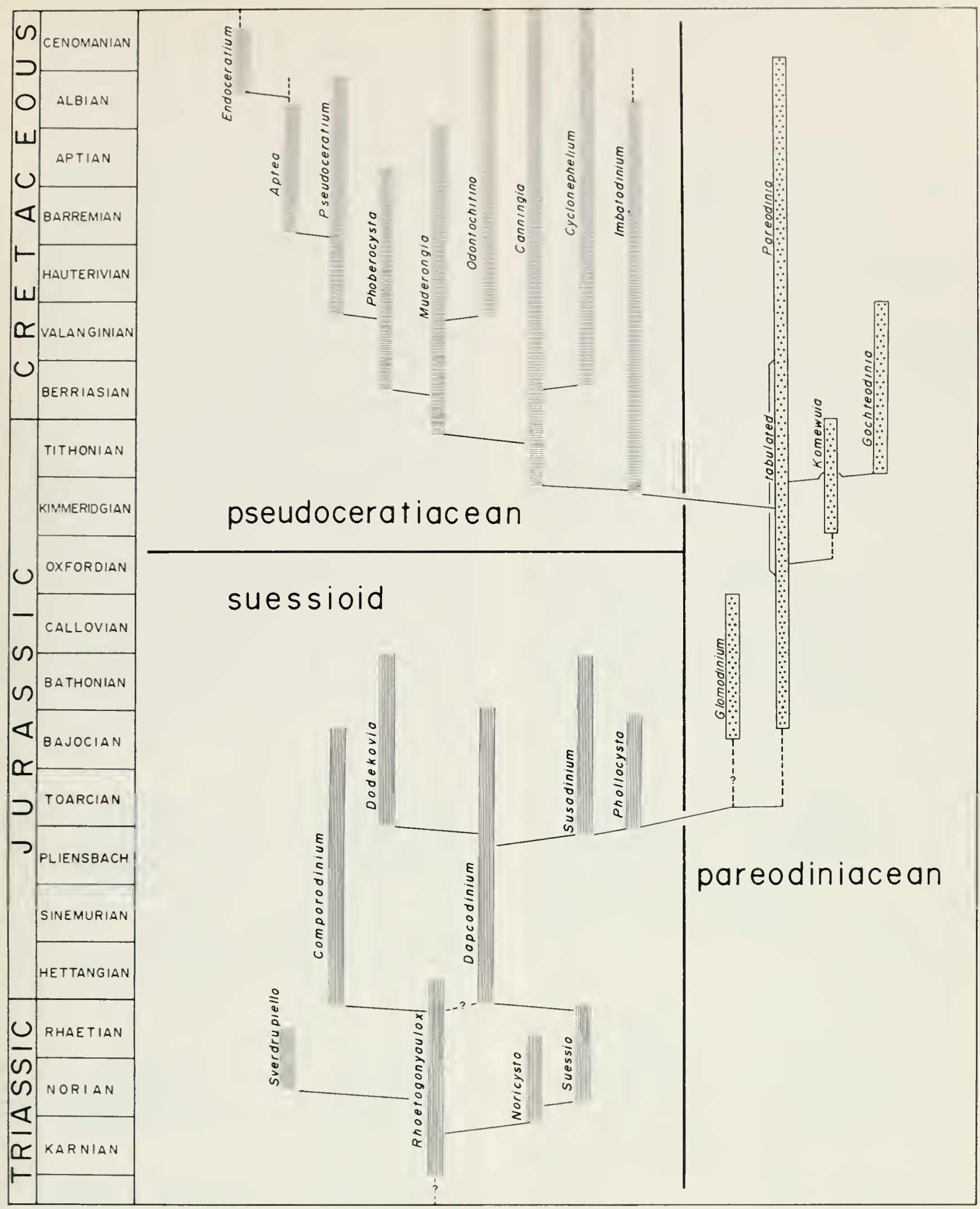

Fig. 7 Phylogeny of the suborder Rhaetogonyaulacineae, based on archeopyle, tabulation, and horn development. Cyclonephelium does not belong to the Pseudoceratiaceae, but is considered to be a derivative. 
a distinct boreal dinoflagellate flora of genera with stabilized archeopyles and reduced plate series (Phallocysta gen. nov., Susadinium gen. nov., Dodekovia gen. nov.). The number of plates in the anterior intercalary series is five as in some Dapcodinium and Comparodinium, which might be their direct ancestors. The new genera exhibit some pareodiniacean features. All have a globular shape with an apical horn and a geniculate intercalary/precingular suture. Dodekovia has an archeopyle limited to the mid-dorsal intercalary and precingular area, preceding earliest precingular archeopyle types (see below). Phallocysta and Susadinium have a 31 archeopyle with an enlarged central opercular plate; the precingular series incorporates only six plates.

Fusion of some plates within the intercalary series has taken place at this time, which could account for the enlargement of the mid-opercular plate relative to neighbouring plates in Phallocysta and Susadinium. Some of the precingular plates have been fused to the cingulum, to each other, or to some of the ventral intercalaries.

The precingular plates of Rhaetogonyaulax, Sverdrupiella, Heibergella, Dapcodinium, and Dodekovia are small relative to the size of the intercalary plates, whereas in Susadinium and Phallocysta the precingulars are enlarged.

The first "true" pareodiniacean cysts evolved in the early Middle Jurassic. The similarity in shape (tearshaped), archeopyle (1), and basic tabulation ( $4^{\prime}$, na, $6^{\prime \prime}$, 6-7"' ') between Phallocysta and the Pareodiniaceae suggests a direct evolutionary lineage. Herngreen and De Boer (1974) reported from the Aalenian of Holland a species they identified as Pareodinia ceratophora. They did not mention the archeopyle type, which is also not evident from their illustration. It would be important to know if the 21 or the 3I type occurred first, in order to establish the ancestry of one archeopyle type to the other. In the Sverdrup Basin the 3I type (Glomodinium Dodekova 1975) predates the 21 type (Pareodinia). It is possible that the 21 type did not occur before the Bathonian (Gocht, 1970) and evolved from the 3I type. Glomodinium (as Pareodinia) was recorded first in the Late Bajocian (Johnson and Hills, 1973; Wiggins, 1975) and extends into the Late Jurassic.

Pareodiniacean cysts exhibiting clear and determinable tabulation patterns have not been recorded earlier than Callovian (Paragonyaulacysta Johnson and Hills 1973 emend.: 4', 3a, 6"',6c, ?6-7'" ', 2pa, 1'" ', 2pv). The tabulation of Pareodinia is not expressed before the Oxfordian, where the first tabulated species occur (Sarjeant, 1962; Brideaux and Fisher, 1976: 4', 2a, 6"', 6c, ?6-7" ', ?pa, 1" "', ?pv). In the Late Jurassic the first apteate pareodiniacean cyst type also occurs (Gochteodinia Norris 1978b).

In the lineage discussed so far, the archeopyle was initiated in mid-dorsal position according to the keystone principle. The adcingular lap-joints became stronger as plate fusion progressed. In the Late Jurassic this process led to the development of cysts which are closely related to the Pareodiniaceae, yet have an (4A2I) archeopyle. Imbarodinium can be regarded as the first pseudoceratiacean cyst evolving directly from the pareodiniacean stock. First occuring species (I. gochtii, I. imbatodinensis etc.) have typically short hypotractal horns and longer-horned species developed subsequently (I. longicornutum). Few forms extend into the late Early Cretaceous after the peak in the Early Neocomian. Basal Cretaceous sediments are characterized by the radiation of the pseudoceratiacean group (Fig. 7). Several closely related genera evolved at this level, which essentially differ from each other in the length and number of horns and the presence or absence of clearly defined endoblasts. These features are probably related to environmental factors, such as water temperature (Dörhöfer, in press). As shown above, all these forms can develop horns in variable number and position, that is postcingular and/or antapical.

We have determined the tabulation of two pseudoceratiacean genera, namely Imbatodinium and Aptea, which represent end members of the lineage. Both formulae are identical: 4', 2a, 6"', 5-6c, ?6-7'" ', ? 1 pa, 1 " " and conform with the tabulation found in tabulated Pareodinia. Two anterior intercalary plates are consistently present in pseudoceratiacean cysts. Throughout the pseudoceratiacean history the advent of genera (Fig. 7) coincided with the development of horns as outlined in Fig. 4, i.e. Muderongia most probably gave rise to Odontochitina, and Aptea was derived from Pseudoceratium (Davey and Verdier, 1974). The similarity in ornament between the latter two can be seen by comparing $A$ and D on Fig. 37. Even stronger ornament (chorate mode) is developed on Heterosphaeridium Cookson and Eisenack 1968 (Fig. 36A, B), which in all other respects resembles Aptea.

Canningia, as here emended, first appears in the latest Kimmeridgian at about the same time as Imbatodinium. These genera are morphologically similar. Both have two antapical horns and one apical horn. Furthermore, the holotype, Canningia reticulata Cookson and Eisenack 1960 , has an asymmetrical archeopyle suture, suggesting intercalary plates incorporated in the operculum. Postcingular horns are weakly developed in Canningia and might link it to Muderongia, which appears slightly later. The earliest species of Muderongia (M. simplex) has relatively short postcingular horns (Fig. 36C, E).

Complete fusion of the intercalary plates with their apical neighbours in Pseudoceratiaceae would result in the development of a (4A) archeopyle, which is characteristic for genera of the suborder Hystrichosphaeridiineae (Norris, 1978a, b).

Cyclonephelium and Canningia have many features in common suggesting the former evolved from the other. Cyclonephelium is more symmetrical (Fig. 33E) and normally does not show horn development. The symmetry may be a result of the intercalary/apical plate fusion and/or horn suppression. 
According to the keystone principle an apical archeopyle should be expected if the adcingular lap-joints remained strong and the mid-dorsal intercalaries fused to the apical plates. The Hystrichosphaeridiineae ((4A)-type) are considered polyphyletic. One lineage has been shown through the pseudoceratiaceans, another one probably evolved from suessioid ancestors to forms like Ellipsoidicrum that was first recorded in the Bathonian (Gocht, 1970; Herngreen and De Boer, 1974); and Lithodinia that was first recorded in the Bajocian (Gocht 1975b). Illustrations of Ellipsoidictium cinctum Klement (Gocht, 1970: pl. 34, figs. 12-19) suggest fusion of the two epitractal adcingular series into one precingular series. All apical (and ?intercalary) plates are removed in archeopyle formation. In Lithodinia jurassica Eisenack 1935 the opercular pieces are removed separately (Gocht, 1975b). This might be considered an ancestral feature similar to the archeopyle mode in Dapcodinium.

Total fusion of the apical plates into one opercular piece would lead to forms like Batiacasphaera and perhaps to chorate forms like Oligosphaeridium. Development of the precingular archeopyle type can be explained by fusion of specific plates, namely the "proto-precingulars" and intercalaries.

The archeopyle of Dodekovia has the typical shape of later precingular $\left(\mathrm{P}_{3}\right)$ archeopyle types; however, it is still in a pre-fusion state, where the operculum consists of separate "proto-precingulars" and intercalary plates. Possible specimens of Dodekovia (Gocht, 1970: pl. 34, figs. 25-29) demonstrate the flexibility of this (IP) archeopyle type, which occasionally involves two opercu- lar pieces of fused intercalary and precingular plates. This is reminiscent of the disintegration archeopyle. Later forms, such as Gonyaulacysta aldorfense Gocht 1970 from the Bathonian of Germany developed single precingular opercula, but latent fusion sutures are occasionally expressed (Gocht, 1970: pl. 30, fig. 3a). The operculum resembles that of Cribroperidinium Neale and Sarjeant 1962 (Fig. 8) from the Lower Cretaceous. Eaton (1976) postulated that the intratabular ridges in Cribroperidinium represent relict boundaries resulting from fusion of a multiplate suessioid area into a larger plate.

The relict boundaries are suppressed in later gonyaulacean species. Dürr and Netzel (1974) confirmed the presence of two or three anterior intercalary plates in right lateral position (transdextral) on the theca of extant Gonyaulax polyedra Stein. We interpret these as relicts of a complete anterior intercalary series, the remainder of which was fused dorsally and left laterally. This is opposed to the pareodiniacean types where the intercalaries are shifted transinistrally (Norris 1978a) and to the peridinioid cysts where they are mid-dorsally placed. Cyst genera, such as Eodinia which develop an (AP) archeopyle and in all other respects resemble Gonyaulacysta, can be explained as an offshoot with weakened adcingular lap-joints. Gocht (1975a) stressed the similarity between Eodinia pachytheca Eisenack 1938 and Gonyaulacysta aldorfense Gocht 1970.

The evolutionary paths of peridinioid cysts are still obscure. Norris (1978b) suggests derivation from the rhaetogonyaulacinean lineage through a shift of the $2 \mathrm{a}$ plate from transinistral to mid-dorsal position. Work by
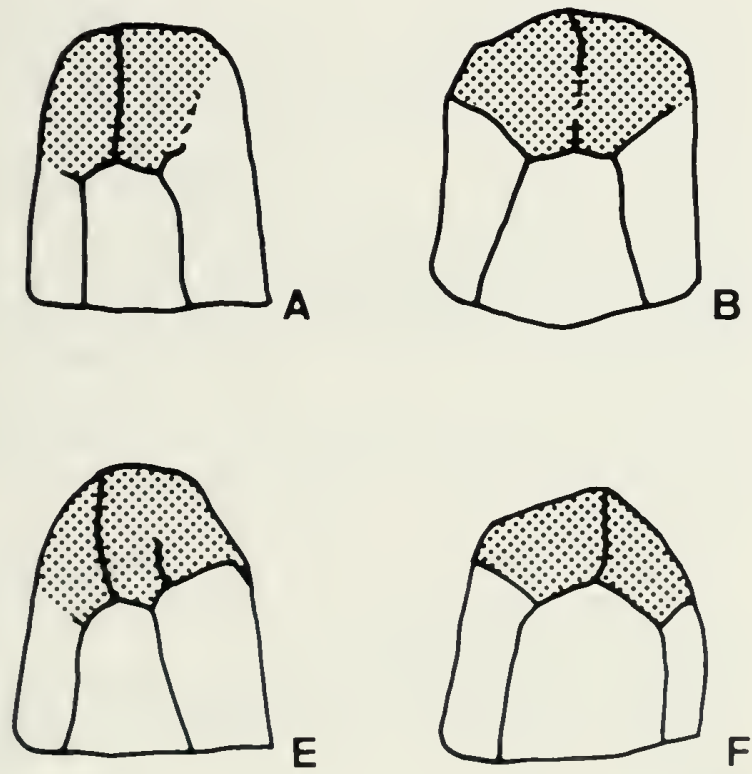
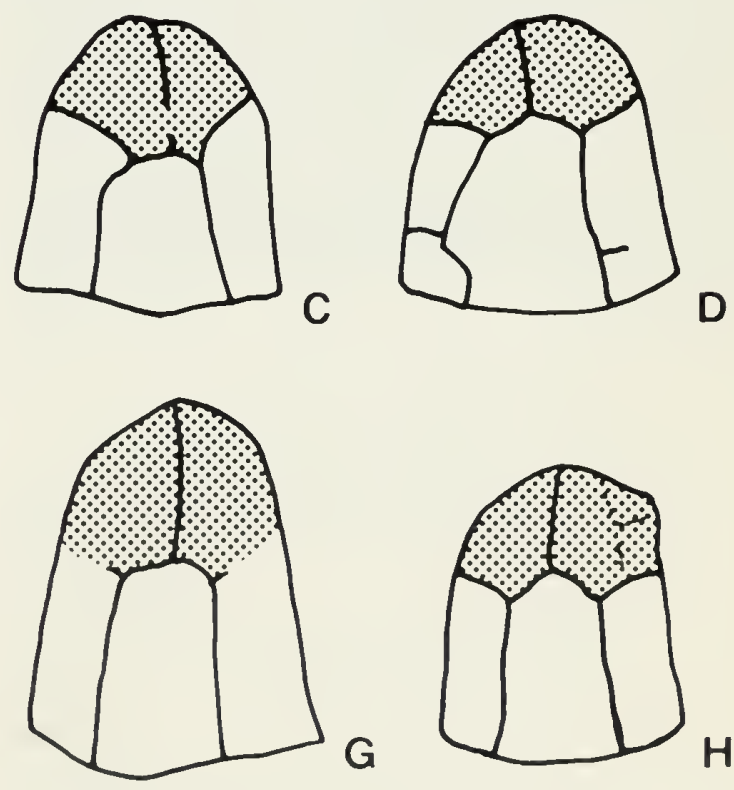

Fig. 8 Fusion tracks on plate 3" of Cribroperidinium orthoceras (Eisenack, 1958) from the Lower Hauterivian of the Hils area (Germany). Fused intercalaries are shaded 
Dörhöfer, Gocht, and Netzel (in preparation) indicates close affinities between modern Ceratium and Peridinium; differences can be explained by plate fusion and interpretation of plate homologues which are partly obscured by differences in bilateral symmetry (i.e. horn position). Both Ceratium (Wall and Evitt, 1975) and Peridinium might date back directly to the pseudoceratiacean lineage. Muderongia simplex Alberti 1961, for instance, closely resembles modern Peridinium species in shape, horn development, and position of intercalary plates (Fig. $36 \mathrm{E}-\mathrm{G})$.

Throughout the lineage discussed above a general trend towards simplification of tabulation and archeopyle is apparent which serves to increasingly stabilize the cyst architecture. This is accomplished through plate fusion and a strengthening of plate sutural bonds.

In summary, seven main evolutionary steps from suessioid to pseudoceratiacean can be discerned:

1. emergence of earliest suessioid cysts from Micrhystridium-type acritarchs; main characteristics are complex tabulation and disintegration archeopyle. (Suessia, Rhaetogonyaulax, Sverdrupiella etc.);

2. reduction of plate and plate series numbers, with retention of the disintegration archeopyle. (Dapcodinium);

3. stabilization of archeopyles in definite positions and further reduction of plate numbers; main characteristics are five intercalary plates and 3I archeopyles (Phallocysta, Susadinium) or 313P archeopyle (Dodekovia);

4. development of the first pareodiniacean cysts with a further reduced intercalary series 1-3a that together constitute the 31 archeopyle. (Glomodinium, Paragonyaulacysta);

5. reduction of the intercalary series from three to two plates (Pareodinia, Gochteodinia with 2I archeopyles) or one (Broomea with II archeopyle);

6. development of pseudoceratiacean cysts, with (AI) archeopyles, achieved through strengthening of api$\mathrm{cal} /$ intercalary sutural bonds. (Imbatodinium);

7. radiation of Pseudoceratiaceae through modifications of horn development and positions. (Pseudoceratium, Muderongia).

\section{Systematic Palaeontology}

\section{Remarks on suprageneric classification}

We have employed Norris's (1978a, b) revised suprageneric classification. The results of this study have shown, however, that some alterations are necessary regarding the taxonomic position of certain genera here considered. The degree of contraction is correlative to palaeolatitudinal distribution patterns and appears sensitive to ecological parameters (mainly temperature) of water masses (Dörhöfer, in press). Family differentiations should not be based solely on the degree of contraction, particularly with proximate (cavate or acavate) cysts, as clear intergradations are developed between cavate and apteate proximate cyst types. The family Pseudoceratiaceae (described below, page 33), on the basis of archeopyle and tabulation, should be transferred to the suborder Rhaetogonyaulacineae. Our understanding of the family is different from Norris's (1978a, b) proposal, as we have included members of the Muderongiaceae and Odontochitinaeceae. The separation of the three families in Norris $(1978 \mathrm{a}, \mathrm{b})$ was mainly based on the presence of endoblasts (Muderongiaceae, Odontochitinaeceae) or absence of endoblasts (Pseudoceratiaceae). The families Muderongiaceae, Pseudoceratiaceae, and Odontochitinaeceae constitute a sufficiently coherent complex to group them together in one family. Accordingly we have emended the family Pseudoceratiaceae (see page 33 ). The family Pseudoceratiaceae is now more widely circumscribed to include new information on archeopyle and tabulation.

We do not regard the presence of endoblasts in the family Sverdrupiellaceae as a valid family criterion. We rather suggest a differentiation based on archeopyle types and tabulation. The family Sverdrupiellaceae becomes redundant, and the genera originally included are here transferred; Broomea to Pareodiniaceae; Hebecysta, Noricysta, and Sverdrupiella to the Rhaetogonyaulacaceae. The taxonomic position of Moesiodinium is questionable. Known characters indicate similarities with Broomea (Lentin and Williams, 1975) and suggest transfer to Pareodiniaceae.

The family Rhaetogonyaulacaceae is emended below (page 23) to include correct reference to pericoelar development, tabulation, and archeopyle.

The family Phallocystaceae is proposed (page 24) to include cysts with four apical and five intercalary plates, and a 3I or 3I3P archeopyle.

The family Pareodiniaceae is emended below (page 30 ) to include reference to the presence or absence of tabulation.

The suborder Rhaetogonyaulacineae now comprises four families: 1) Rhaetogonyaulacaceae; 2) Phallocystaceae; 3) Pareodiniaceac; 4) Pseudoceratiaceae. 


\section{Description}

Division Pyrrhophyta Pascher

Class Dinophyceae Fritsch

Order Peridiniales Haeckel

Suborder Rhaetogonyaulacineae Norris

Family Rhaetogonyaulacaceae Norris emend.

\section{Type Genus}

Rhaetogonyuulax Sarjeant emend. Harland et. al. 1975.

\section{Emended Family Diagnosis}

Proximate (cavate or acavate) cysts with a suessioid tabulation of 2-6', 4-6a, 5-14", 5-14' ', 1-9p, 1-4" "' and a disintegration archeopyle. The family Rhaetogonyaulacaceae is emended here to include proximate cysts with sussioid tabulation of $2-6{ }^{\prime}, 4-6 a, 5-14^{\prime}$ ', 5-14' ' ', 1-9p, $1-4^{\prime}$ ' ' ' . This formula differs slightly from that proposed by Norris (1978b). The archeopyle is the disintegration type rather than intercalary. The family includes both cavate and acavate proximate cysts.

\section{Dapcodinium Evitt emend.}

Dapcodinium Evitt 1961:996.

Mancodinium Morgenroth 1970:352.

Maturodinium Morgenroth 1970:353.

Opaeopsomus Evitt in Pocock 1972:96-97.

Opaeopsomus Pocock (non Evitt) 1972-Lentin and Williams 1973: 101 .

\section{Type Species}

Dapcodinium priscum Evitt 1961.

\section{Emended Diagnosis}

Proximate dinoflagellate cysts with circular to ovoidal ambitus; apex occasionally slightly pointed. Tabulation is variably expressed (sutural crests, faint sutures, aligment of ornament): 4', 4-5a, 7"', 6-7c, 6-7'" ', 1-4p, 1" "'. Disintegration archeopyle $4 \mathrm{~A}+4-5 \mathrm{I}+7 \mathrm{P}$ initiating mid-dorsally between the apical and intercalary series. Ornament, if present, is low.

\section{Remarks}

Pocock (1972:96-97) vaguely described the new genus Opaeopsomus and attributed it to Evitt. Because the type species O. wapellensis Pocock 1972 falls within the diagnosis of Dapcodinium, it is here transferred. Opaeopsomus, therefore, becomes redundant. The disintegration archeopyle of Dapcodinium is apparent from our own observations, but was also illustrated by Evitt (1961: 100, text-figs. $12,18-20$, pl. 119, fig. 6). Slight differences in archeopyle development between Mancodinium and Malurodinium represent various stages of the disintegration archeopyle. Both "genera" were encountered in our arctic material. Besides minute differences regarding expressions of plate boundaries, they are identical in tabulation and overall morphology and appear synonymous with Dapcodinium.

Dapcodinium inornatum (Morgenroth) comb. nov. Fig. 25E

Maturodinium inornatum Morgenroth 1970:354, pl. 13, Figs. 5-8.

Dapcodinium semitabulatum (Morgenroth) comb. nov. Fig. $25 \mathrm{G}$

Mancodinium semitabulatum Morgenroth 1970:352, pl. 12 , figs. $3-6$; pl. 13 , figs. $1-4$.

Dapcodinium wapellense (Pocock) comb. nov. et emend.

Figs. 9, 24J

Opaeopsomus wapellensis Pocock 1972:97, pl. 24, fig. 14.

\section{Emended Diagnosis}

Proximate dinoflagellate cysts with circular ambitus and slight apical horn. Tabulation expressed by sutural crests, surface otherwise smooth. Tabulation $4^{\prime}, 5 a, 7^{\prime \prime}, 7 \mathrm{c}$, $7 "$ ', 4p, 1" "', 5s. Disintegration archeopyle, $4 \mathrm{~A}+5 \mathrm{I}+7 \mathrm{P}$ initiating at $2 \mathrm{a}$.

\section{Remarks}

The species occurs in the Toarcian of Arctic Canada. It was reported by Pocock (1972) from the Callovian of western Canada.

\section{Noricysta Bujak and Fisher 1976 emend.}

Noricysta Bujak and Fisher 1976:58.

\section{Type Species}

Noricysta fimbriata Bujak and Fisher 1976.

\section{Remarks}

The genus is here emended to accommodate the presence of tabulation outlined by low sutural crests. The tabulation is $6^{\prime}, 8 \mathrm{a}, 10^{\prime \prime}, 9 \mathrm{c}, 10^{\prime \prime} ', 6 \mathrm{p}, 6^{\prime \prime}{ }^{\prime \prime}$, ?s. Disintegration archeopyle, $6 \mathrm{~A}+8 \mathrm{I}+10 \mathrm{~Pa}$, initiating between the 
apical and intercalary series. In all other respects the diagnosis stays as originally proposed.

Noricysta fimbriata Bujak and Fisher 1976 emend. Figs. 10, 22A-C, Figs. 21 B, D-G, 24A-C

Noricysta fimbriata Bujak and Fisher 1976:60, pl. 9, figs. $1-5$.

\section{Remarks}

The species is here emended to agree with the tabulation stated in the revised generic diagnosis. The sutural crests are distally serrated. The antapical pericoel is generally more strongly developed. The antapex is often pointed. The emendation is based on investigation of topotype material (Sandy Point L-46 well, Melville Island, locality 1 on Fig. 2).

\section{Sverdrupiella Bujak and Fisher 1976}

Sverdrupiella Bujak and Fisher 1976:45-48.

\section{Type Species}

Sverdrupiella septentrionalis Bujak and Fisher 1976.

\section{Sverdrupiella sabinensis Bujak and Fisher 1976}

Figs. 19A-G, 20C-E, 22H

Sverdrupiella sabinensis Bujak and Fisher 1976:49-50, pl. 3, figs. 1-3.

\section{Remarks}

Results of SEM work show that the blunt spines are arranged penitabularly (Figs. 19F, 20D). The species develops a typical disintegration archeopyle (Figs. 19C, $20 \mathrm{C}-\mathrm{E}$ ). A circular opening not related to plate configuration is very often developed on the ventral epitract (Figs. 19C, E, 20C-E). The function of this opening is unknown, but these claustra (pericoelar openings) are common features of cavate genera (Norris and Dörhöfer, 1976). Apical views of longitudinally compressed specimens (Fig. 19G) look like S. usitata Bujak and Fisher 1976 and suggest synonymy. An endoblast is often not developed.

Family Phallocystaceae fam. nov.

\section{Type Genus}

Phallocysta gen. nov.

\section{Diagnosis}

Proximate (cavate or acavate) cysts with a tabulation of $4^{\prime}$, 5 a, 6-9", 5-9" ', 1-2" "'; archeopyle 3I or 3P3I. An apical horn is usually present.

\section{Comparodinium Morbey emend. Wille and Gocht (in press)}

Comparodinium Morbey 1975:43.

Comparodinium Morbey emend. Wille and Gocht (in press).

\section{Type Species}

Comparodinium koessenium Morbey 1975.

\section{Remarks}

Wille and Gocht (in press) described forms identical to our material on which the suture lines were more visible and allowed elucidation of the tabulation as $1 \mathrm{pa}, 5^{\prime}, 5-6 \mathrm{a}, x^{\prime \prime}$, $x c, x^{\prime \prime} ', 5 \mathrm{p}, 1 \mathrm{pv}, \mathrm{l}^{\prime \prime}$ " and the archeopyle as $2 \mathrm{~A}_{3-4}$. They observed all intergradations between proximate $(C$. aquilonium sp. nov.) and chorate ( $C$. koessenium Morbey 1975) species. The genus is placed provisionally into the family Phallocystaceae fam. nov. despite its different archeopyle.

\section{Comparodinium aquilonium sp. nov.}

Figs. 26E, I, 28A-H

\section{Etymology}

Latin aquilonius, northern.

\section{Provenience}

Lower Savik Formation, Toarcian. Elf Wilkins E-60 well, 1950 ft., Mackenzie King Island, Sverdrup Basin, Arctic Canada.

\section{Holotype}

Slide WI 1950-A, ROM 36470, 35.6/95.2, Fig. 26E. Size: $31 \mu \mathrm{m}$.

\section{Diagnosis}

A proximate dinoflagellate cyst with thin, but highly refractive autophragm, smooth with scattered granules. Outline elongated ovoidal, apically rounded to slightly pointed, antapically rounded. Tabulation partially apparent from faint sutures 5', 5-6a, 6", ?c, ?"' ', ?" ". Archeopyle $2 \mathrm{~A}_{3,4}$. 


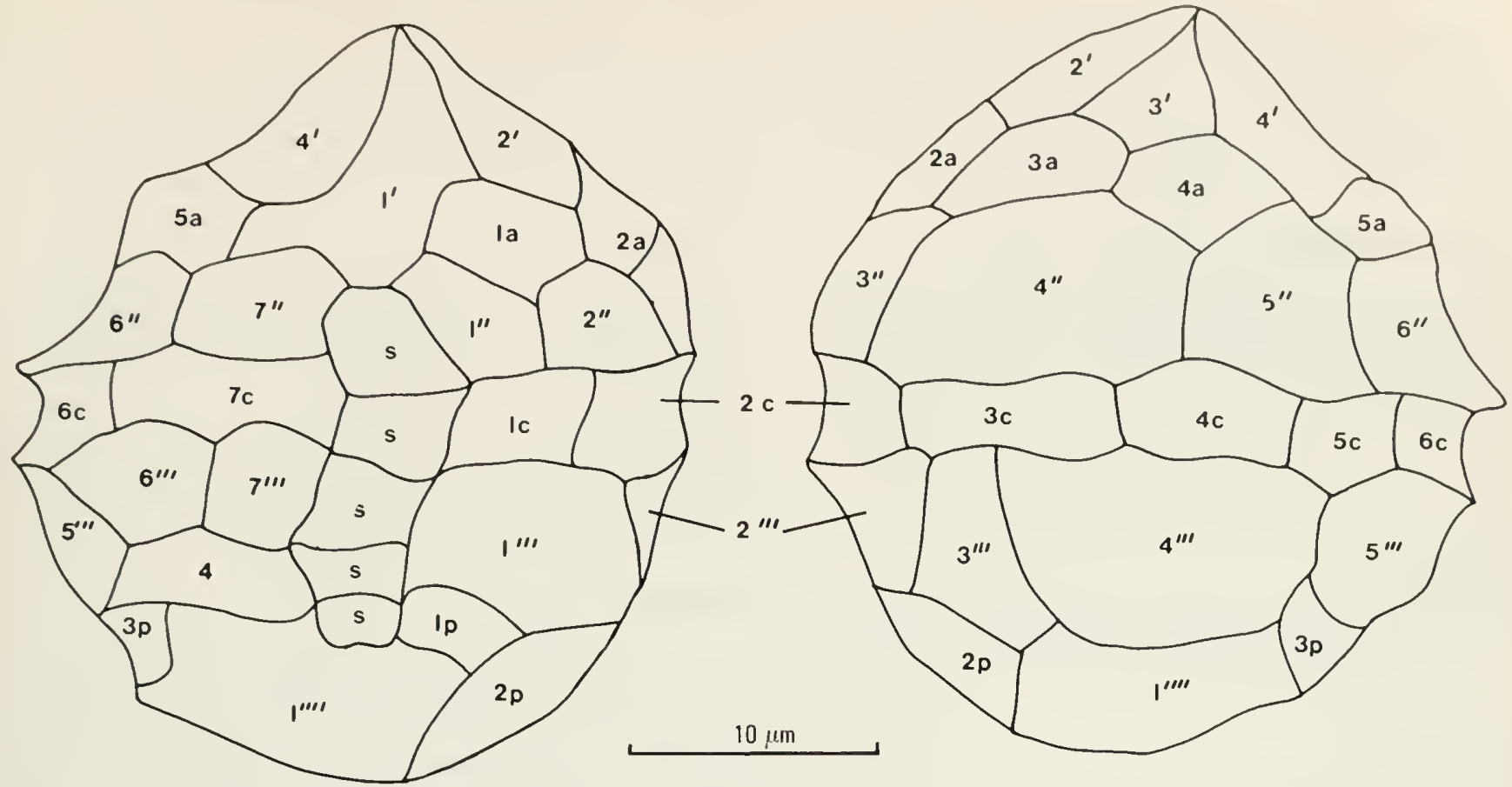

Fig. 9 Dapcodinium wapellense (Pocock) comb, nov., showing tabulation pattern: 4', 5a, 7"',7c, 7"' ', 4p, 1" "', 5s. Archeopyle initiates at 2a.

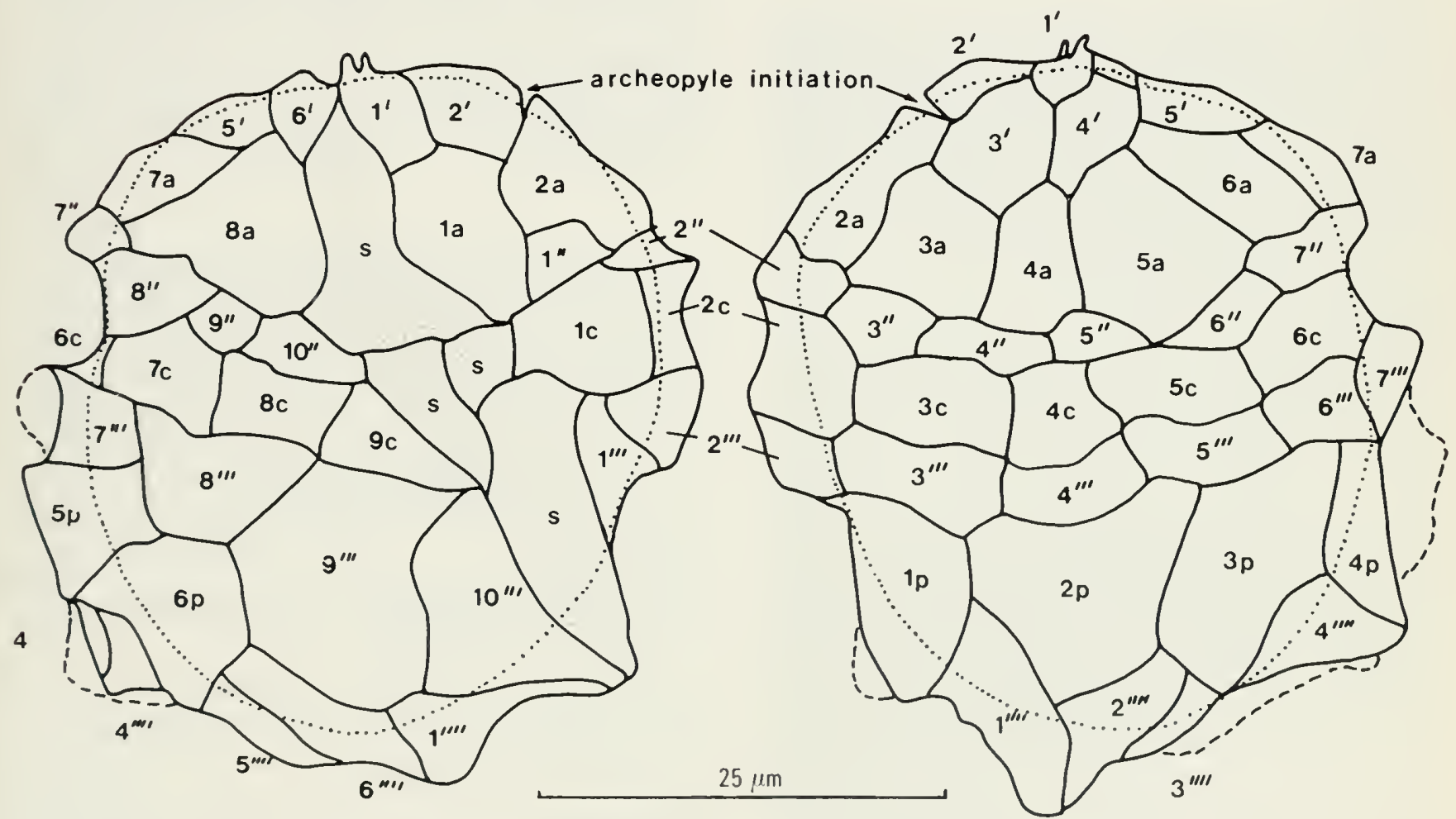

Fig. 10 Noricvsta fimbriata Bujak and Fisher emend., showing tabulation and archeopyle initiation at 2'/2a. Tabulation: 6', 8a. 10", 9c, 10" ", 6p, 6" " 4s. 


\section{Remarks}

Normally no tabulation is apparent, except for the archeopyle outlined and accessory sutures. The faint cingulum is occasionally expressed. A hypotractal fold perpendicular to the long axis of the cyst is common. Length $27(20) \mu \mathrm{m}$; breadth 19(23)25 $\mu \mathrm{m}$.

\section{Stratigraphic Range}

Toarcian to Bajocian/Bathonian of the Lower Savik Formation and the Jaeger Member of the Sverdrup Basin, and the Lias $\delta-\xi$ of southern Germany (Wille and Gocht, in press).

\section{Dodekovia gen. nov.}

\section{Etymology}

Named after Dr. Lilia Dodekova, Bulgarian Academy of Science, Sofia.

\section{Type Species}

Dodekovia syzygia sp. nov.

\section{Provenience}

Jaeger Member, Savik Formation, Bathonian. Reindeer Peninsula, Ellef Ringnes Island, Sverdrup Basin, Arctic Canada.

\section{Diagnosis}

Proximate dinoflagellate cysts with elongate ovoidal to spherical shape. Apex slightly pointed, occasionally with a short horn. Cyst wall two-layered, fibrous between endo- and periphragm. Surface of periphragm smooth, granulate, or finely reticulate. Tabulation faintly expressed. Tabulation formula: $4^{\prime}, 5 a, 9^{\prime \prime}, 8 c, 9^{\prime \prime}{ }^{\prime}, 2 p$, 2" ", 4s; archeopyle 3P3I.

\section{Remarks}

Dodekovia gen. nov. differs from Tectatodinium Wall 1967 in archeopyle formation ( $\mathrm{P}_{3}$ in Tectatodinium). Dodekovia resembles Cribroperidinium; however, the latter has a different tabulation (no anterior intercalary plates, Eaton 1976), is much larger, and has a long apical horn. A common feature in Dodekovia is the presence of sutural traces on the operculum. Apteodinium normally lacks tabulation and has a $P_{3}$ archeopyle. Gocht ( 1970 :pl. 34, figs. 25-29) figured several specimens from the Bathonian of Germany as indeterminate genera, which most probably represent specimens of Dodekovia. The removal of one or two opercular pieces, each representing fused intercalary with precingular plates, are vestiges of the disintegration archeopyle. Tectatodinium gochtii Dodekovia 1975 (Gocht 1970:pl. 34, fig. 25) is transferred to Dodekovia.
Dodekovia syzygia sp. nov.

Figs. 11, 23B, E, H, 26A-D, F, G

\section{Etymology}

From Greek syzygios, conjugated. Refers to the compound operculum.

\section{Provenience}

Jaeger Member, Savik Formation, $1 \mathrm{~m}$ above the base. Reindeer Peninsula, Ellef Ringnes Island, Sverdrup Basin, Arctic Canada.

\section{Holotype}

Slide ED 1030-4A, ROM 36628, 55.9/98.6, Fig. 26A-D. Size: $30 \mu \mathrm{m}$.

\section{Diagnosis}

A species of Dodekovia with spherical to ovoidal cyst body. Phragma two-layered, fibrous between endo- and periphragm. Ornament densely granulate to punctate. Small apical horns often present. Tabulation $4^{\prime}, 5 \mathrm{a}, 9^{\prime \prime}$, $8 \mathrm{c}, 9^{\prime \prime}$ ', 2p, 2" '", 4s; archeopyle 3P3I.

\section{Remarks}

Dodekovia gochtii (Dodekova) comb. nov. differs by its reticulate ornament. ?Meiourogonvaulax acanthosphaera (Sarjeant) Sarjeant 1976 resembles D. syzygia, but differs in archeopyle (AI), tabulation, and size. Length 25(27)30 $\mu \mathrm{m}$; breadth $18(22) 26 \mu \mathrm{m}$ (12 specimens).

\section{Stratigraphic Range}

Toarcian-Bathonian of the Savik Formation of the Sverdrup Basin.

\section{Dodekovia gochtii (Dodekova) comb. nov.}

Tectatodinium gochti Dodekova 1975:31, pl. 3, figs. 8, 10-13.

\section{Phallocysta gen. nov.}

\section{Etymology}

Named after its resemblance to a phallus, Greek phallos, emblem of the god Bacchus.

\section{Type Species}

Phallocista cumekes sp. nov.

\section{Provenience}

Jaeger Member, Savik Formation, Bathonian, Reindeer 

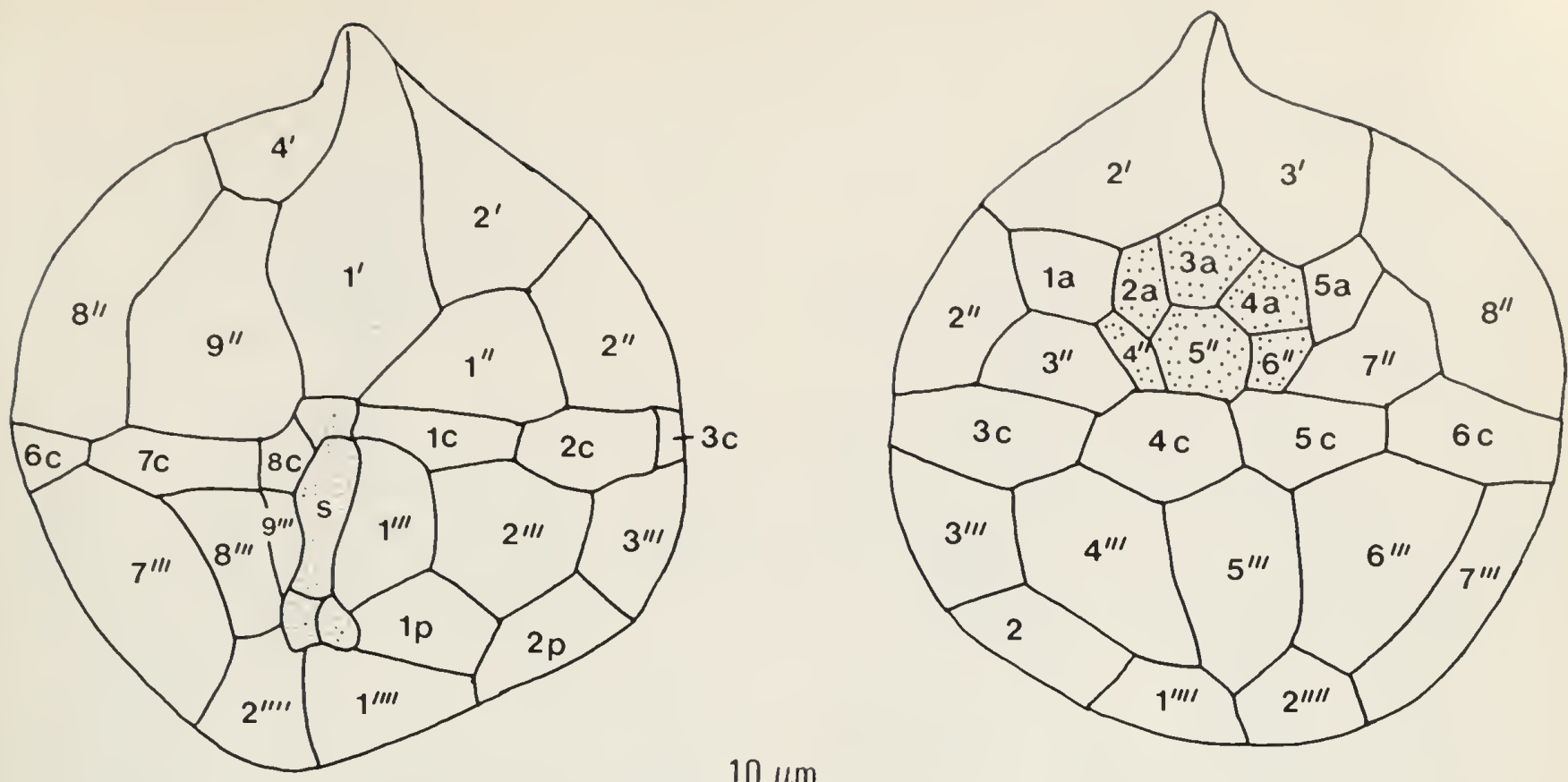

$10 \mu \mathrm{m}$

Fig. 11 Dodekovia syzrgia sp. nov., showing tabulation and compound (PI) archeopyle. Tabulation: 4', 5a, 9", 8c, 9" '. 2p, 2" "', 4s; archeopyle: $\left(3 P_{4-6} 3 I_{2-4}\right)$.

Peninsula, Ellef Ringnes Island, Sverdrup Basin, Arctic Canada.

\section{Diagnosis}

Proximate dinoflagellate cysts; elongated, tapering apically with two large antapical hemispherical protuberances. Phragma two-layered, surface smooth or bearing low but variable ornament. Phragms of epitract thin; phragms of hypotract thickened. Tabulation 4', 5a, 6"', ?6c, 6" ', ?" "'; archeopyle 3I.

\section{Remarks}

The genus differs from Glomodinium Dodekova 1975 and Pareodinia Deflandre emend. Gocht 1970 by having large differences in wall thickness between the hypotract and the epitract, and the formation of two bulbous protuberances on the antapex. The intercalary plates are typically elongate in Phallocista. It also differs from Pareodinia (2I) by the number of plates in the operculum. Susadinium gen. nov. has smaller and more protuberances in pre- and postcingular positions.

\section{Phallocysta eumekes sp. nov.}

Figs. 12, 24D, E, G, 26H, J, K, 27A-I

\section{Etymology}

Named for protuberant epitract, Greek eumekes, rather long.

\section{Provenience}

Jaeger Member, Savik Formation, $120 \mathrm{~m}$ above base, Bathonian. Reindeer Peninsula, Ellef Ringnes Island, Sverdrup Basin, Arctic Canada.

\section{Holotype}

Slide ED 1031-4a, ROM 36631, 35.2/100.2, Fig. 29K. Size: $64 \mu \mathrm{m}$.

\section{Diagnosis}

A species of Phallocysta with a sharply pointed apical horn and two large antapical bulges flanking the sulcus. Phragma two layered; periphragm bearing evenly but sparsely distributed granules; endophragm punctate. Tabulation 4', 5a, 6"', ?6c, ?6"' ', ?" ". Archeopyle 3I, consisting of elongated plates with an enlarged central plate.

\section{Remarks}

A sharp decrease of wall thickness occurs immediately anterior to the cingulum. The thin epitract is variably stretched out, the apical horn more sharply pointed and the wall more longitudinally folded as extension increases. The cingulum is occasionally faintly expressed. Length $41(47) 64 \mu \mathrm{m}$; breadth 25(34)42 $\mu \mathrm{m}$.

\section{Stratigraphic Range}

Toarcian to Bajocian/Bathonian of the Lower Savik Formation and the Jaeger Member of the Sverdrup Basin. 

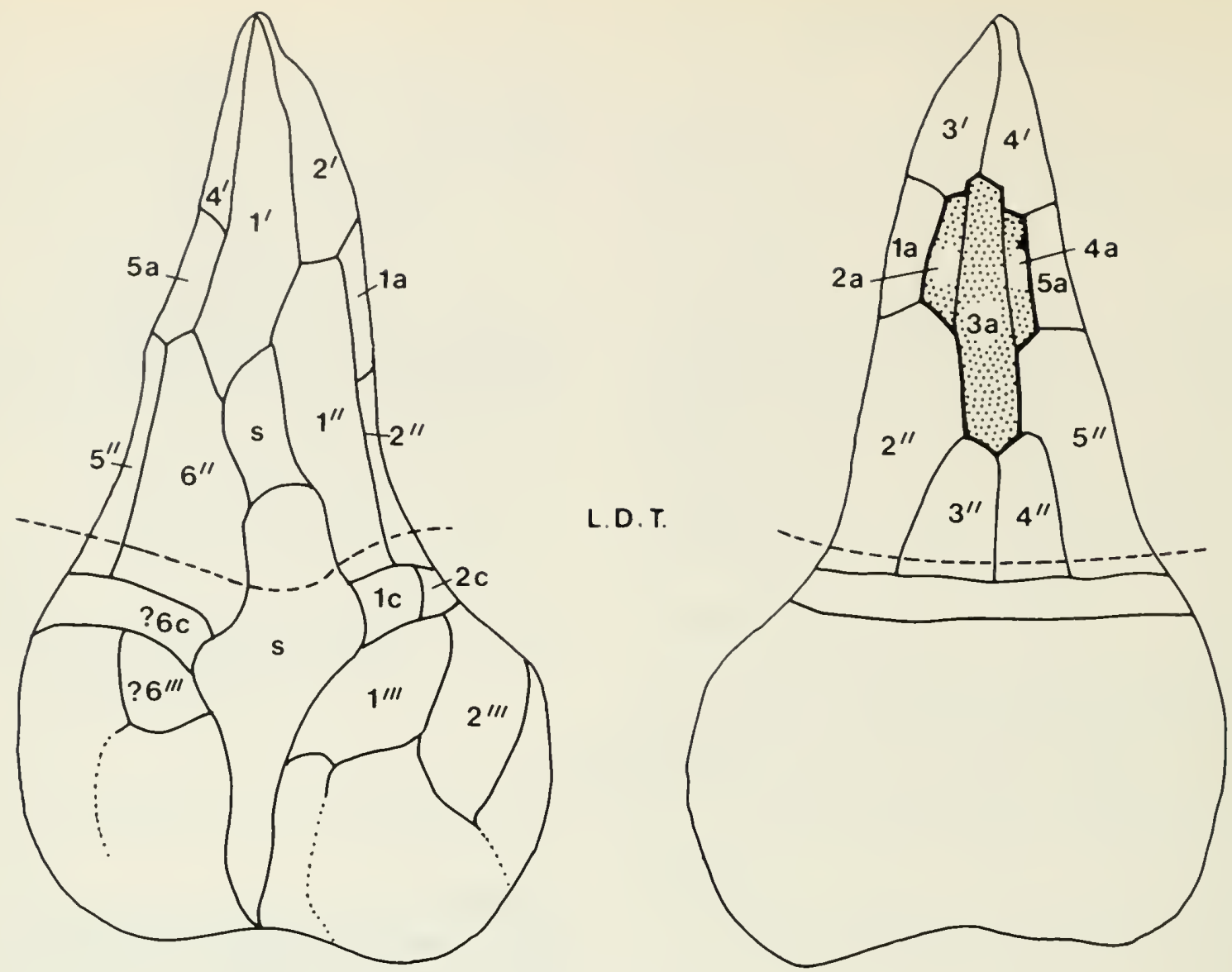

Fig. 12 Phallocysta eumekes sp. nov., showing tabulation and archeopyle. Tabulation: 4', 5a, 6", ?6c, ?6" ' '; archeopyle: 3I 2 - 4. L.D.T.: line of differential thickening.

Susadinium gen. nov.

\section{Etymology}

Named after its superficial resemblance to a pig. Latin sus, swine.

\section{Type Species}

Susadinium scrofoides sp. nov.

\section{Provenience}

Lower Savik Formation, Toarcian. Reindeer Peninsula, Ellef Ringnes Island, Sverdrup Basin, Arctic Canada.

\section{Diagnosis}

Proximate dinoflagellate cysts with elongated cyst body, tapering apically, antapically rounded. Short intratabular protuberances delineating the pre- and postcingular series and less pronounced the anterior intercalary plates. Surface of periphragm smooth to granulate. Tabulation formula: ?4', 5a, 6", ?6c, 5" ', ? I" "'; archeopyle $3 \mathrm{I}_{2-4}$.

\section{Remarks}

The genus differs from Pareodinia Deflandre emend. Gocht 1970, Glomodinium Dodekova 1975, and Gochteodinia Norris 1978b, by having a more numerous series (5a) of intercalaries. It differs from Sverdrupiella Bujak and Fisher 1976 by the lack of an endoblast and from Heibergella Bujak and Fisher 1976 and all the above genera by having short blunt protuberances. Phallocysta nov. gen. has a similar tabulation and archeopyle, but has only two hypotractal protuberances and is more elongated.

\section{Susadinium scrofoides sp. nov.}

Figs. 13, 24F, H, I, K, 25A-D

\section{Etymology}

Named after Sus scrofa, the European wild boar.

\section{Provenience}

Lower Savik Formation, near base. Reindeer Peninsula, Ellef Ringnes Island, Sverdrup Basin, Arctic Canada. 

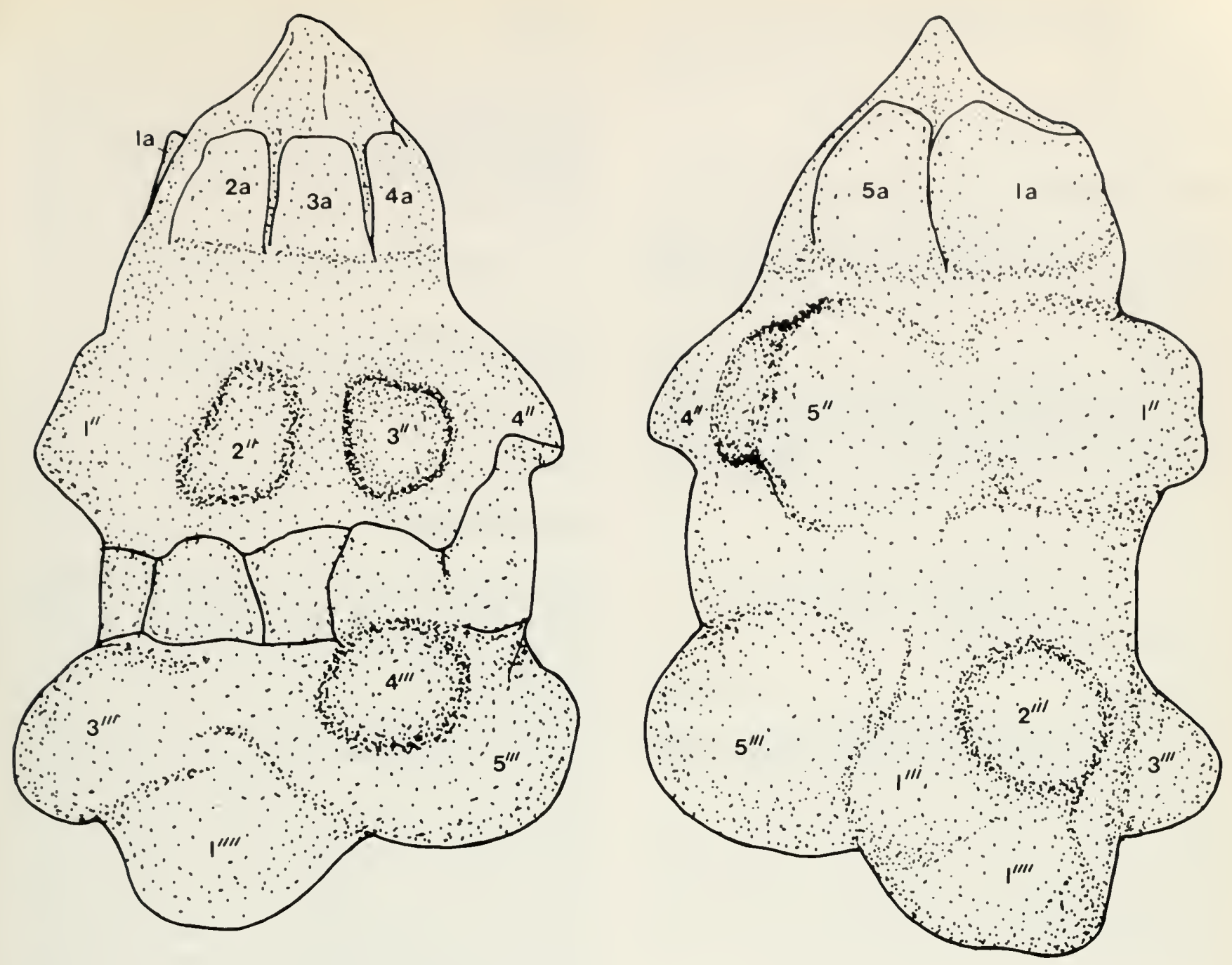

Fig. 13 Susadinium scrofoides sp. nov., showing tabulation as interpreted from the low bulges and showing the archeopyle. Tabulation: ?4', 5a, $5^{\prime \prime}$, ?c, 5 " ", 1" "; archeopyle $3 \mathrm{I}_{2-4}$

\section{Holotype}

Slide ED 1038-2a, ROM 36598, 49.3/105.1 Fig. 241. Size $38 \mu \mathrm{m}$.

\section{Diagnosis}

A species of Susadinium with a short apical horn and rounded to angular intratabular protuberances in the preand postcingular plate series. Autophragm thin, smooth to granulate. Cingulum and sulcus broad. Tabulation $4^{\prime}, 5 \mathrm{a}$, 6", ?6c, 5" ', ?I" "'; archeopyle $3 \mathrm{I}_{2-4}$.

\section{Remarks}

Autoblast often dorsoventrally compressed. The precingular series consists of five short rounded protuberances, the postcingular of three short dorsal and two larger bulging ventral protuberances flanking the sulcus. The apical horn is often sharply pointed with an apical angle of $35-40^{\circ}$. Sutural granules sometimes delimit the apical plates and ventral cingular plates. The tabulation formula was obtained from plate sutures and intratabular protuberances. The broad sulcal area might include additional plates of the pre- and postcingular series, which are not provided with intratabular protuberances.

Cantulodinium protuberatum Wall 1965 superficially resembles $S$. scrofoides, but due to its inadequate description and illustration closer comparisons are not possible. Length 29(38)42 $\mu \mathrm{m}$; width 19(22)26 $\mu \mathrm{m}$.

\section{Stratigraphic Range}

Toarcian to Bathonian of the Savik Formation (lower Jaeger and basal Upper Member), Sverdrup Basin. 
Family Pareodiniaceae Gocht emend.

\section{Type Genus}

Pareodinia Deflandre emend. Gocht 1970.

\section{Emended Diagnosis}

Proximate cysts; tabulation (if discernable) of $4^{\prime}, 1-3 a$, $6 ", 6$ " ', 1" "'; archeopyle 1-3I. Usually an apical horn is present.

\section{Remarks}

After this emendation the following genera belong to the family: Caligodinium, Glomodinium, Gochteodinia, Komewuia, Paragonyaulacysta, Paranetrelytron, and Pareodinia.

\section{Gochteodinia Norris $1978 b$}

\section{Gochteodinia Norris 1978b.}

\section{Type Species}

Gochteodinia villosa (Vozzhennikova) Norris 1978b. Figs. 33F, G, 34G.

Imbatodinium villosum Vozzhennikova 1967:56, pl. 12, figs. $1-3$; pl. 13, figs. $1-3$; pl. 14, figs. 1, 2; pl. 15, figs. 1, 2.

Pareodinia dasyforma nom. subst. pro Imbatodinium villosum Vozzhennikova 1967 - Wiggins 1975:107, pl. 5 , figs. 3,4 .

\section{Gochteodinia villosa (Vozzhennikova) Norris $1978 \mathrm{~b}$}

\section{Remarks}

SEM studies suggest penitabular position of the processes, not non-tabular as stated in the generic diagnosis. The apteate ornament ranges from blunt to palmate terminating, short to elongated processes, with microgranular elements (Fig. 33G). Only specimens with 2I archeopyles have been found in the present study and by Thusu (I977); yet Wiggins (1975:107) reports 3I varieties from Alaska. The cingulum is indicated by a broad belt free of processes (Fig. 33F), which was also observed by Thusu (1977).

Gochteodinia verrucosa (Vozzhennikova) comb. nov.

Imbatodinium verrucosum Vozzhennikova 1967:56, pl. 12, fig. 6 .

Pareodinia verrucosa (Vozzhennikova) Wiggins 1975: 105.

\section{Remarks}

The species is here transferred to Gochteodinia because of its apteate ornament. Specimens from the Canadian Arctic have penitabular elements, ranging from low verrucae to short baculae; intergradations to $G$. villosa-type ornamentation have been observed. The archeopyle is 2 I.

\section{Komewuia Cookson and Eisenack 1960}

Komewuia Cookson and Eisenack 1960:257. Kalyptea Cookson and Eisenack 1960:256.

\section{Type Species}

Komewuia glabra Cookson and Eisenack 1960.

\section{Emended Diagnosis}

Proximate cyst with elongate ovoidal to spheroidal outline and an apical and antapical horn. Tabulation occasionally indicated, archeopyle 2I. Kalyptra present or absent.

\section{Remarks}

Cookson and Eisenack (1960:256-257) erected two genera for pareodiniacean forms with an antapical horn: Komewuia and Kalyptea. The holotype of Kalyptea ( $K$. diceras Cookson and Eisenack 1960 ) is somewhat more elongate than the monospecific genus Komewria $(K$. glabra Cookson and Eisenack 1960). The former genus was characterized by the presence of a kalyptra, with or without an antapical horn. The latter genus was based on the presence of an antapical horn and an intercalary archeopyle. Gocht (1970) considered Kalyptea as probably synonymous with Pareodinia as the presence of a kalyptra is a typical pareodiniacean feature. Komewuia exhibits a clear archeopyle and the original description better circumscribes pareodiniacean forms with an antapical horn than that of Kalyptea, therefore Komewuia is the preferred homonym. Specimens from the Canadian Arctic exhibited 2I archeopyles (Fig. 34F).

As indicated by Wiggins (1975:110) Netrelytron Sarjeant 1961 also looks the same and probably is synonymous; however; because Sarjeant (1976:15-16) maintains that Netrelytron is cavate, we desist from synonymizing it. The sole difference between Komewuia and Pareodinia is the presence of an antapical process in Komewuia.

Komewuia diceras (Cookson and Eisenack) comb. nov.

Kalyptea diceras Cookson and Eisenack 1960:256-257, pl. 39, fig. 1.

Kalyptea diceras Cookson and Eisenack 1960-Wiggins 1975: 110, pl. 5. figs. 6-9. 
Komewia glabra Cookson and Eisenack 1960

Fig. $34 \mathrm{~F}$

\section{Remarks}

If further investigations should prove that Netrelveron is a junior synonym of Komewuia. Netrelvtron stegastum Sarjeant 1961 would become junior to $K$. glabra, as the presumed endoblast is the sole difference between the two species.

\section{Paragonyaulacysta Johnson and Hills emend.}

Paragoniaulacista Johnson and Hills 1973:207.

\section{Type Species}

Paragoniaulacysta calloviensis Johnson and Hills 1973.

\section{Emended Diagnosis}

Proximate dinoflagellate cysts with elongate ovoidal outline. Apical horn always present, antapex \pm rounded. Tabulation marked by pronounced sutural crests. Surface smooth, granulate, verrucate or finely reticulate. Tabulation $4^{\prime}, 3 \mathrm{a}, 6^{\prime \prime}, 6 \mathrm{c}, 6^{\prime \prime}$ ', $2 \mathrm{p}, 2 \mathrm{pv}, \mathrm{l}^{\prime \prime}$ "', ?s; archeopyle $3 \mathrm{I}_{1-3}$.

\section{Remarks}

The genus is emended to accommodate the tabulation and archeopyle stated above.

\section{Paragonyaulacysta calloviensis Johnson and Hills emend.}

Paragonvaulacysta calloviense Johnson and Hills 1973:207, pl. 2, figs. 9, 13, 17.

\section{Remarks}

The species is here emended to accord with the emended generic diagnosis and to restrict it to specimens with smooth autophragm. $P$. retiphragmata sp. nov. differs by having a reticulate autophragm.

\section{Paragonyaulacysta retiphragmata sp. nov.}

Figs. 14, 29D-F

\section{Etymology}

Latin rete, net, Greek phragma, corral or fence; referring to the reticulate surface of the autophragm.
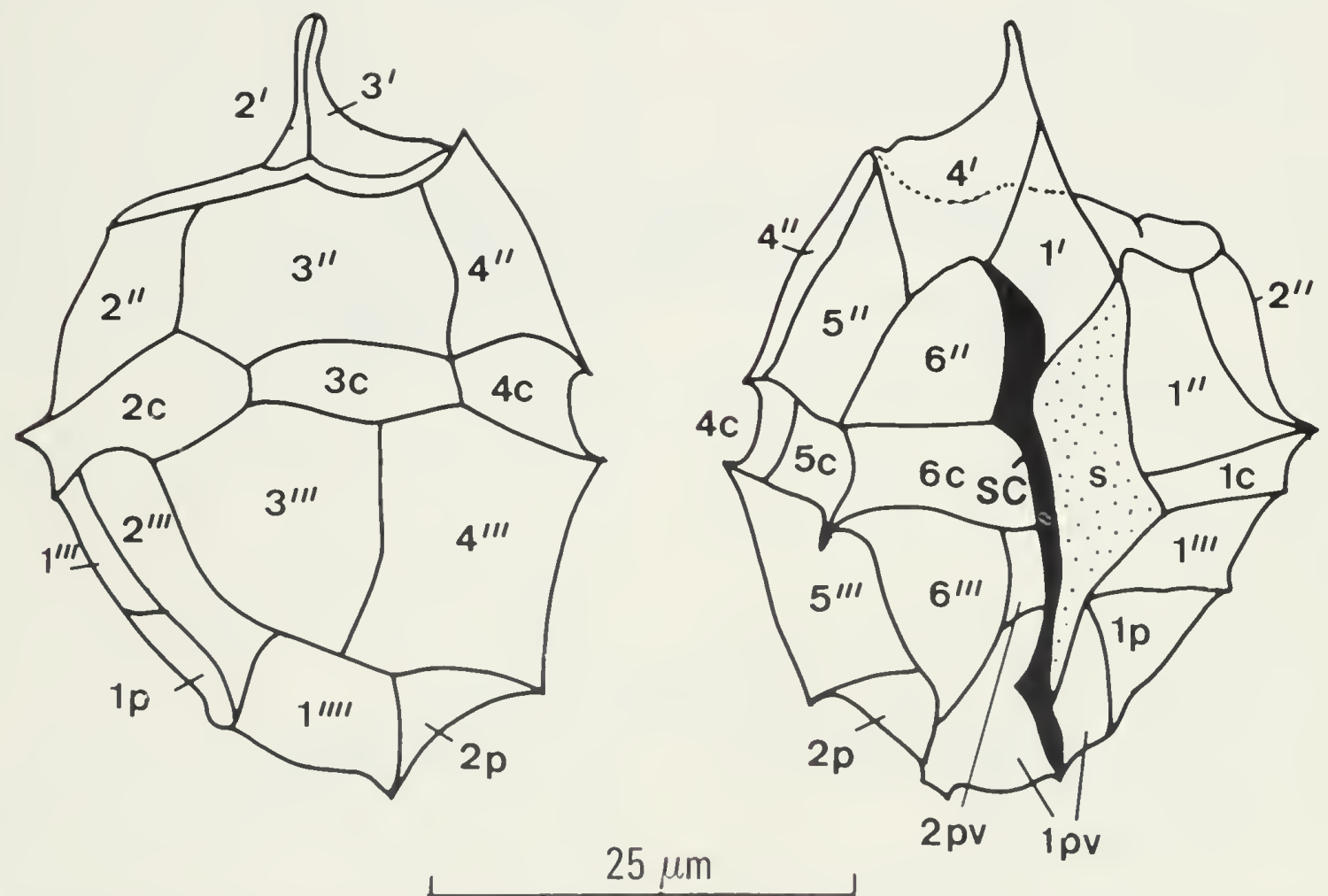

Fig. 14 Paragonsaulacista reluphragmata sp. nov., holotype, showing tabulation and archeopyle. Tabulation: 4', 3a, 6", 6x, 6" ", 2p, 2pv, 1", ", ?s, archeopyle 31 I - 3. SC: sulcal crest 


\section{Provenience}

Savik Formation, $110 \mathrm{~m}$ below the top (1260 $\mathrm{ft}$. cutting Sample). Elf Jameson Bay C-31 well, Prince Patrick 1sland, District of Franklin, Northwest Territories, Canada.

\section{Holotype}

Slide JB 1260A, ROM 36529, 55.1/105.1. Figs. 29D-F. Size: $48 \mu \mathrm{m}$.

\section{Diagnosis}

A species of Paragomyalacysta with finely reticulate autophragm and punctate sutural crests. Tabulation 4', 3a, $6^{\prime \prime}, 6 \mathrm{c}, 6^{\prime \prime}$ ', 2p, 2pv, 1"' ', ?s; archeopyle $31_{1-3}$.

\section{Remarks}

The reticulum consists of very fine irregular meshes $(0.25-1.0 \mu \mathrm{m})$. The height of the sutural crests is about $3 \mu \mathrm{m}$. In all other respects the species corresponds to $P$. calloviensis. Length $6 \mathrm{I}(54) 48 \mu \mathrm{m}$; breadth $45(41) 35 \mu \mathrm{m}$.

\section{Stratigraphic Range}

Callovian, Elf Jameson Bay C-31 (307-406 m).

\section{Pareodinia Deflandre emend. Gocht 1970}

Pareodinia Deflandre 1947:402.

Pareodinia Deflandre emend. Gocht 1970:153.

Pareodinia Deflandre emend. Wiggins 1975:103.

\section{Type Species}

Pareodinia ceratophora Deflandre emend. Gocht 1970: 153-156.

\section{Remarks}

The original generic diagnosis mentioned the globular shape and apical horn. Pareodinia ceratophora Deflandre 1947 was assigned as type species. The holotype is embedded in flint from a glacial boulder. It appears to be corroded and poorly preserved, seemingly having pyrite aggregates within the cyst.

Gocht (1957) grouped Pareodinia with Pseudoceratium Gocht 1957, Odontochitina Deflandre 1935, Ceratocysridiopsis Deflandre 1937, and Nammoceratopsis Deflandre 1938 into the family Pareodinidae Gocht.

Evitt (1961) included forms with an apical archeopyle in Pareodinia but later corrected this to include only intercalary archeopyles (Evitt 1967).

Sarjeant (1966) erected Paranctrelytron to incorporate Pareodinia-like cysts with an endoblast. This was disputed by Wiggins (1975).
Gocht (1970) noted that the type specimen of Pareodinia does not show any archeopyle, cingulum, or sutures, leaving only the variable shape to define the genus. He then examined topotype material and concluded that Pareodinia ceratophora has a 21 archeopyle. Pareodinia was emended to include forms of elongate shape with an apical horn and occasionally pointed antapex, smooth or granulate to slightly tabulated, having a kalyptra retained only under good preservation and gentle preparation, and having a 21 archeopyle.

Sarjeant (1972) allocated two more species to the genus: Pareodinia groenlandica Sarjeant and P. apotomocerastes Sarjeant, both having 21 archeopyles. He also maintained Paranetrelytron as a distinct genus (Sarjeant, 1972, 1976).

Archeopyles of 3I type were found in pareodiniacean cysts by Johnson and Hills (1973), who emended Pareodinia Deflandre emend. Gocht to include both 21 and 31 archeopyles. Wiggins (1975) reviewed the family Pareodiniaceae and emended the genus Pareodinia to include species which accord to the tabulation formula $7 \mathrm{a}$. cl., 6', 6a, 6" $6^{\prime \prime}$ ', 3" "' (a. cl.: apical closing plates) and which have archeopyles formed by the loss of one, two, or three intercalary plates. After this emendation he regarded the following genera as synonymous with Pareodinia: Broomea Cookson and Eisenack 1958; Pluriarvalium Sarjeant 1962; Paranetrelytron Sarjeant 1966; and Imbatodinium Vozzhennikova 1967. This emendation left the genus too widely circumscribed (Norris, 1978b). We consider Broomea as a distinct genus which has a 11 archeopyle (Wiggins, 1975; Norris, 1978b). We agree, however, in the treatment of Pluriarvalium as junior to Pareodinia. Latent tabulation traces are expected in all proximate cysts and the occasional presence does not justify generic separation (Gocht, 1970; Wiggins, 1975; see also discussion on Pseudoceratium). Only when strong sutural crests are developed such as in Paragonyaulacysta Johnson and Hills 1973 does the presence of tabulation warrant generic distinction. Different tabulation formulae for "Pluriarvalium"-types have been given by a number of authors:

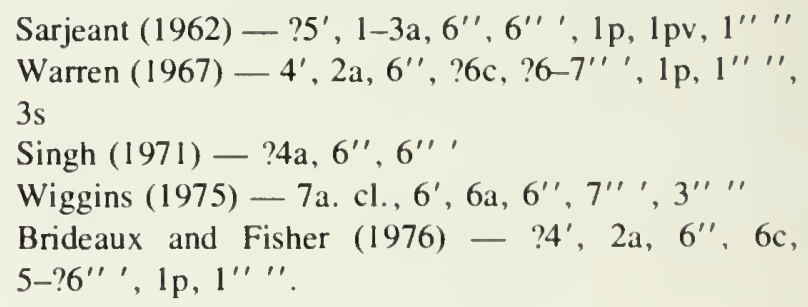

Warren's (1967) and Brideaux and Fisher's (1976) interpretations differ only in the number of postcingular plates, which are difficult to deternine. We agree with Warren's interpretations of ?6-7"' . We have found no evidence for more than two anterior intercalary plates and have not been able to identify any apical closing plates. 
Fanily Pseudoceratiaceae Eisenack (1961) emend.

\section{Type Genus}

Psendoceratium Gocht 1957.

\section{Emended Diagnosis}

Proximate (cavate or acavate, smooth to apteate); horns in up to five positions ( 1 apical, 2 antapical and 2 postcingular); ornament reduced or lacking, in penitabular or nontabular arrangement; tabulation is intermediate between suessiod and gonyaulacoid; archeopyle Al. This is expressed by the logogram AI, sus-gon, ap, 1-2aa, 1-2 pc, pr, non-abs-pen.

\section{Aptea Eisenack emend. Davey and Verdier emend.}

Aprea Eisenack 1958:394.

Doidyx Sarjeant 1966:206.

Aprea Eisenack emend. Davey and Verdier 1974:641642.

\section{Type Species}

Aptea polymorpha Eisenack emend.

\section{Remarks}

Essentially we agree with the emendation of the genus as proposed by Davey and Verdier (1974) but some additional emending remarks are necessary to circumscribe more closely the archeopyle. The archeopyle is (4A21); tabulation formula: 4', 2a, 6"', 5-6c, 6"' ', 1p, $1^{\prime \prime} "$, ?3-6s. The apteate ornament is better developed in the circumferential area with both ventral and dorsal areas being virtually devoid of ornament. The ornament is usually penitabular with less frequent intratabular elements.

Some species of Aptea are considered to be transitional to cavate types, as the ornament is developed on an otherwise smooth autophragm; but the terminal ends of the processes tend to fuse. Total fusion would result in the formation of cavate forms like Endoceratium (Fig. 15).
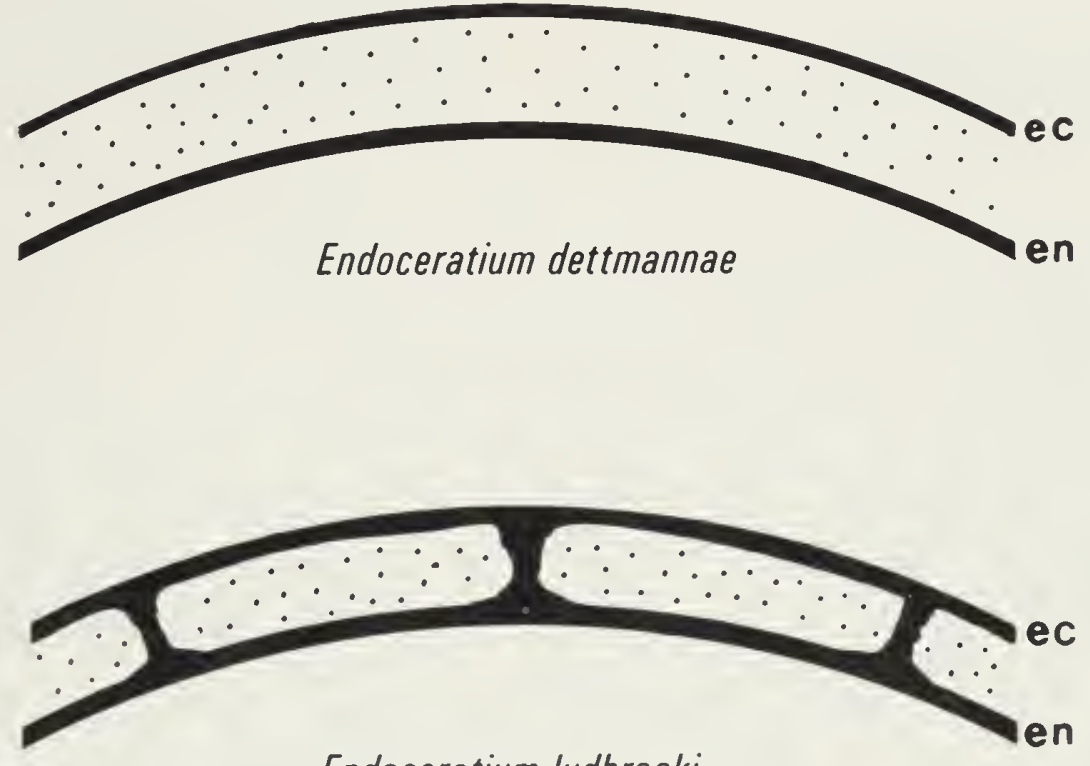

Endoceratium ludbrooki

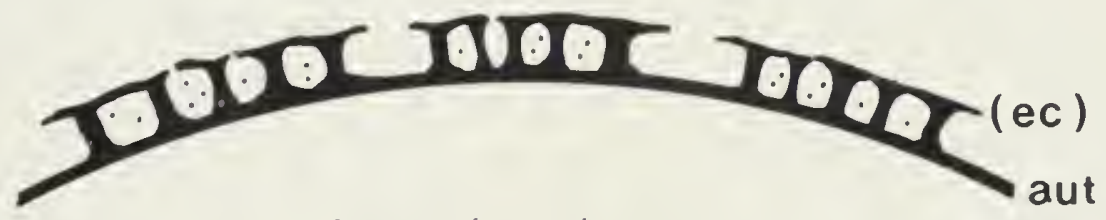

Aptea polymorpha

Fig. I5 Schematic transection through the cyst wall of species of Endoceratium and Aptea. to show the transition between cavate (Endoceratum) and apteate forms (Aptea). ec: ectophragma; en: endophragma; aut: autophragma. 
Transitional forms between Aprea and Endoceratium do exist. The type species E. ludbrookiae (Cookson and Eisenack) Vozzhennikova 1965 exhibits broad supporting ridges between the endophragm and periphragm (Norvick and Burger, 1976). As already partially expressed by Davey and Verdier (1974) the following criteria are particularly important in differentiating Aptea from similar genera: asymmetry of the cyst body, considerable reduction of horns, always ornamented, (4A2I) type archeopyle. Cyclonephelium Deflandre and Cookson 1955 and Bariacasphaera Drugg emend. are typically asymmetrical and most probably have an (4A) archeopyle. Muderongia Cookson and Eisenack 1958 and Phoberocysta Millioud 1969 have two postcingular horns. Odontochitina Deflandre 1936 contains only smooth forms. Aptea is morphologically similar to Heterosphaeridium and Pseudoceratium, occupying an intermediate position between them. The processes become increasingly closer, longer, and more slender proceeding from Pseudoceratium to Heterosphaeridium (compare Figs. 36B, 37A, D).

The following species agree with the emended generic diagnosis:

Aptea polymorpha Eisenack emend.

Aptea anaphrissa (Sarjeant) Stover and Evitt 1978.
Aptea atradalica (Cookson and Eisenack) Davey and Verdier 1974.

Aptea eisenacki (Davey) Davey and Verdier 1974.

Aptea securigera Davey and Verdier 1974.

\section{Aptea polymorpha Eisenack emend.}

Figs. 16, 37A, 38A-F, 39A-F

Aptea polymorpha Eisenack 1958, p. 393.

\section{Emended Description}

Autoblast subcircular to egg-shaped in outline, dorsoventrally flattened. Slight outward bulging occurs sometimes in the position of the three (occasionally four) horns which are marked by ornamental differentiation. These positions correspond to apical (left), antapical, and right postcingular horns. Either or both of the latter two horns may not be developed in all specimens, the postcingular horn being suppressed first. The axis connecting the apical and antapical horns is always shifted to the left, the cyst being always asymmetrical. The autoblast is rather thick-walled. Its surface is finely pitted to granulate. Often sutures are marked by relatively broad pandasutural zones, representing intercalary growth bands, characterized by striations perpendicular to the plate boundaries. Pandasutural areas
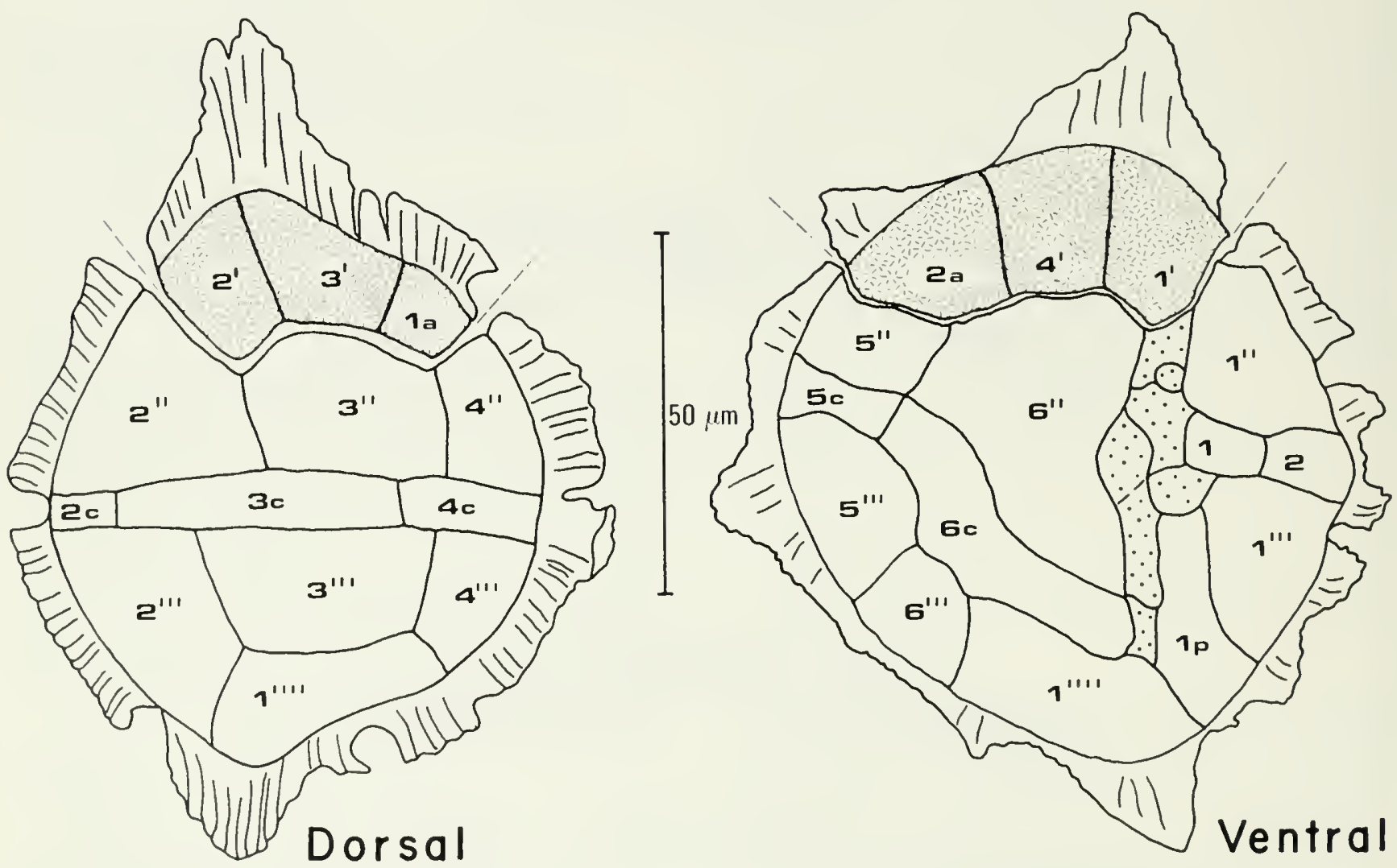

Fig. 16 Aprea polymorpha Eisenack 1958, showing tabulation and archeopyle. Tabulation: 4', 2a, 6", 6c, 6" ', 1" '", 7s; archeopyle: (4A2I). 
are particularly distinct on the epitract along the archeopyle suture, less so on the hypotract. Tabulation formula: 4', 2a, 6", 5-6c, 6" ', 1p, 1"' ", ?3-6s.

Ornament on the cingulunt, ventral plates $6 \mathrm{c}$ and 6 " ' and the sulcus is reduced or absent. Plate lp may be indistinct, particularly regarding its boundary with 1 " ' The sulcal area is comprised of anterior, posterior, and left sulcal plates, and faint lines may indicate the presence of accessory plates. The position of a flagellar pore is indicated by a ring of low ridges to the left of the anterior sulcal plate.

The ornament is somewhat variable, comprising baculae, which are broadly based on the autoblast, tapered slightly and widened distally (Fig. 37A). The height of ornamental elements varies between 5 and $15 \mu \mathrm{m}$ except over the three (or four) horns which are marked by longer processes reaching to about $30 \mu \mathrm{m}$ at the apex and antapex. In these areas the ornament is appressed 80 the autoblast and is alnost parallel with the autophragnt. Distal fusion of process tips occurs frequently, especially on the horns.

The right postcingular horn position (a left postcingular horn is seldom indicated) is clearly related to the overall morphology of the cyst body. Its position can be expressed through the hypotractal divergence angle, which is measured between the axis connecting the apical and antapical horns and the point where the extended axis of the right postcingular horn intersects the cingulum on the dorsal side (Fig. 17). This divergence angle exhibits a linear relationship to the extension ratio (length/width: $\mathrm{L} / \mathrm{W}$ ). The longer the cyst body becomes, the smaller is the hypotractal divergence angle (Fig. 17). An extreme

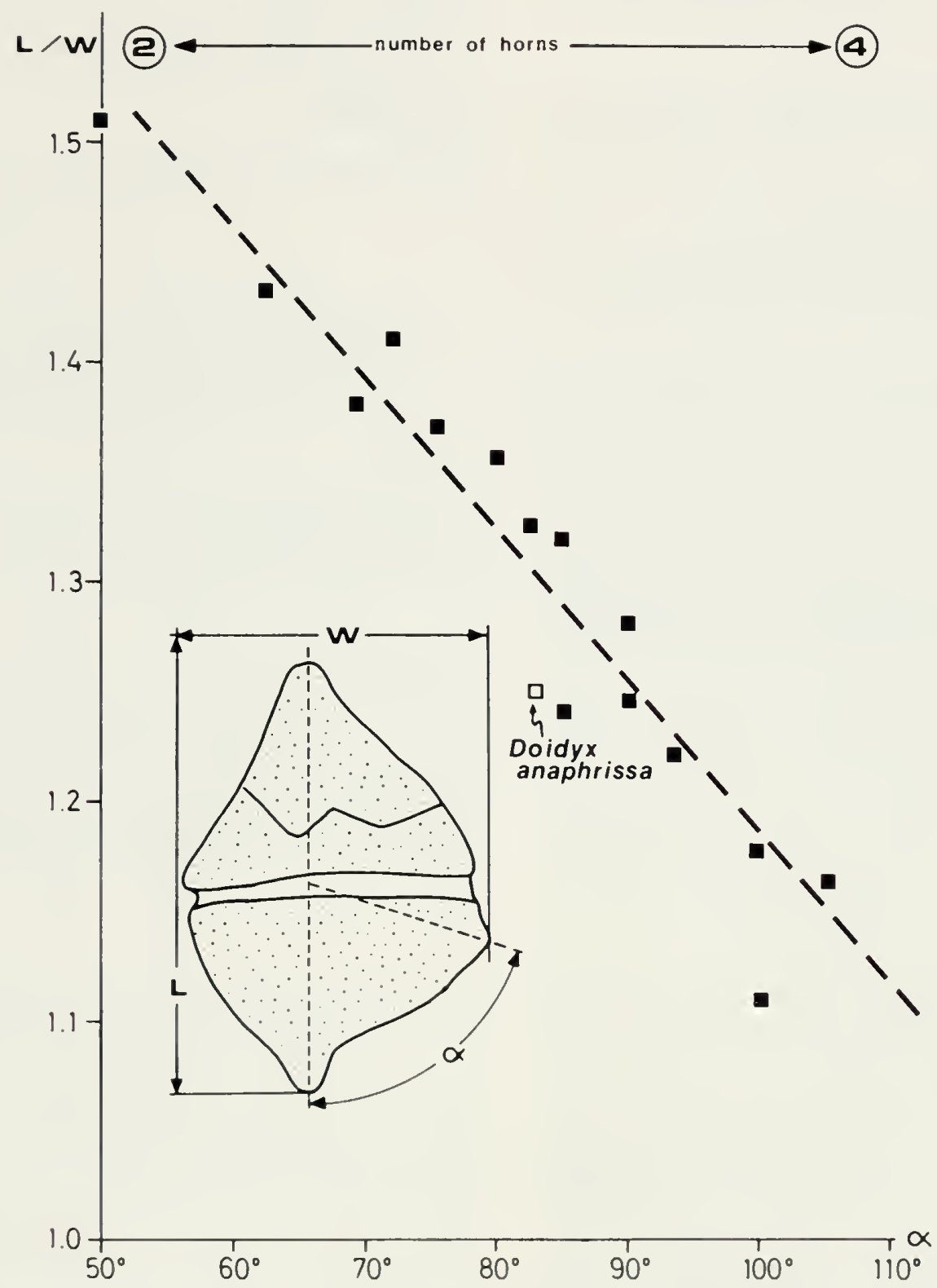

Fig. 17 Hypotractal horn divergence of Aptea polymorpha Eisenack 1958. "Doidvx" anaphrissa is plotled to indicale its close affinity. 
case is the disappearance of the postcingular horn once $\mathrm{L} / \mathrm{W}$ is greater than 1.6; at the other extreme, forms with low extension ratios might exhibit indications of a left postcingular horn. The horn positions, however, become harder to determine with decreasing $\mathrm{L} / \mathrm{W}$ as the horn bulges become indistinct and the outline almost circular. The presence of a fourth horn is restricted to these compact varieties.

The archeopyle is (4A21); its suture is zigzag in shape and asymmetrical, the left part being strongly deflected to the apex, the right part to the cingulum. Ventrally a sulcal notch is developed between plates $1^{\prime}$ and $6^{\prime \prime}$, and another notch occurs where the $5^{\prime \prime}$ and $6^{\prime \prime}$ meet at the archeopyle suture. Dorsally the suture line dips down at the junctions of $2^{\prime}, 2^{\prime \prime}, 3^{\prime \prime}$, and of $3^{\prime}, 3^{\prime \prime}, 4^{\prime \prime}$. The presence of intercalary plates is responsible for the asymmetry of the archeopyle suture and of the autoblast. The sutures between the intercalary and the apical plates are very faint.

\section{Canningia Cookson and Eisenack emend.}

Canningia Cookson and Eisenack 1960:251.

Canningia Cookson and Eisenack emend. Cookson and Eisenack $1961: 72$.

\section{Type Species}

Canningia reticulata Cookson and Eisenack 1960.

\section{Remarks}

The emendation by Cookson and Eisenack (1961) to include forms with rounded antapices is unwarranted because the generic concept became too wide and heterogenous (Singh, 1971:322). As originally proposed, only species which clearly indicate the presence of two antapical horns should be included. Furthermore, some species, such as the type species, $C$. reticulata indicate the presence of two postcingular horns by slight bulges. The wider generic concept would make the genus almost indistinguishable from Batiacasphaera Drugg emend.

The type species Canningia reticulata exhibits an asymmetrical archeopyle suture suggesting an (AI) archeopyle and pseudo-ceratiacean affinity.

The genus is therefore emended: proximate dinoflagellate cysts with roughly five-sided to almost circular outline. Apex prominent, antapex broadly indented between two rounded antapical horns. Cingulum occasionally indicated by faint surface ornamentation and/or slight bulges representing postcingular horns. Surface smooth or with low but variable ornament. Archeopyle (A1), formed along an asymmetrical zigzag suture line. Tabulation was not determined. Some species presently in Canningia do not exhibit the (Al) archeopyle and are omitted from the genus. Their archeopyle suture is symmetrical and the antapex founded. We, therefore, consider only the following species as belonging to Canningia:
Canningia reticulata Cookson and Eisenack 1960
C. aspera Singh 1971
C. colliveri Cookson and Eisenack 1960
?C. granulata Morgenroth 1966
C. hirtella (Alberti) Millioud 1969
C. rugulosa (Clarke and Verdier) Stover and Evitt 1978
C. scabrosa Cookson and Eisenack 1970
C. senonica Clarke and Verdier 1967.

The remaining species have been transferred to Batiacasphaera Drugg emend.

\section{Heterosphaeridium Cookson and Eisenack 1968}

\section{Type Species}

Heterosphaeridium conjunctum Cookson and Eisenack 1968.

\section{Heterosphaeridium heteracanthum (Deflandre and Cookson) Eisenack and Kjellström 1971 \\ Fig. 36A, B}

Hystrichosphaeridium heteracanthum Deflandre and Cookson 1955:276, pl. 2, fig. 5.

Heterosphaeridium heteracanthum (Deflandre and Cookson) Eisenack and Kjellström 1971:451, pl. 4, fig. 4.

\section{Remarks}

Recent work (Dörhöfer, in preparation) presents evidence for a $(4 \mathrm{~A})+(2 \mathrm{I})$ archeopyle indicating pseudoceratiacean affinity. The archeopyle initiates as a (4A2I) type (Fig. $36 \mathrm{~B})$; breakdown of the operculum into two opercular pieces occurs later and is probably due to weak apical/intercalary sutures.

\section{Imbatodinium Vozzhennikova emend.}

Imbatodinium Vozzhennikova 1967:52.

Batioladinium Brideaux 1975:1240.

Necrobroomea Wiggins 1975:111.

\section{Type Species}

Imbatodinium kondratjevi Vozzhennikova emend. 


\section{Emended Diagnosis}

Elongate proximate dinoflagellate cysts with an apical horn and two hypotractal (antapical) horns; surface of autophragm smooth or with very low granules, vernucate or spines. Tabulation, when evident, is $4^{\prime}, 2 \mathrm{a}, 6^{\prime \prime}, 6 \mathrm{c}$. 6-7"', 1-2p, 1" "', ?pv, ?s. The epitract is enlarged relative to the hypotract leaving the cingulum close to the antapex. Archeopyle ( 4 A2I). The operculum occasionally remains attached to the sulcus. The emendation is necessary to describe the tabulation and to state the presence of an (Al) archeopyle instead of an apical one.

\section{Remarks}

This genus differs from all pareodiniacean genera by its mode of archeopyle formation. It differs from Phoberocysta, Pseudoceratium, and Aptea by the lack of ornament, the horn positions, and the posteriorly displaced cingulum. Muderongia, Odontochitina, and Endoceratium are cavate and also possess postcingular horns. The following species accord with the emended diagnosis:

Imbatodinium kondratjevi Vozzhennikova emend.

I. exiguum (Alberti) comb. nov.

I. gochtii (Alberti) comb. nov.

I. imbatodinensis Vozzhennikova 1967

I. jaegeri (Alberti) comb. nov.

I. longicornutum (Alberti) comb. nov.

I. micropodum (Eisenack and Cookson) comb. nov.

I. pelliferum (Alberti) comb. nov.

The main distinguishing criteria are surface ornamentation, which is always very low, and length of horns. Surface patterns are best recognized under the SEM, and are illustrated for several species (Figs. 31B, 32A-C).

\section{Imbatodinium kondratjevi Vozzhennikova emend.} Figs. 30A-E, 31 A-F, 34C, E

Imbatodinium kondratjevi Vozzhennikova 1967:55, pl. 9, figs. 1-9; pl. 10, figs. 1-6; pl. 11, figs. 1-3; pl. 15, figs. $1-4$.

\section{Remarks}

The species is emended to include reference to an (Al) archeopyle, probably involving four apical and two intercalary plates. In all other respects our specimens from the Sverdrup Basin conform with the original description.

The presence of two anterior intercalary plates could be established under the interference contrast microscope; however, all sutures are very faint and are not easily photographed. These sutures are not expressed by sculptural elements and are not normally visible with SEM, suggesting that they constitute differentiations within the phragma or are expressed on its inner surface.
One aberrant specimen displayed 21 archeopyle. The ornament is cornugated-granular. A mid-ventral internal thickening (omphalos) is usually present (as in all pseudoceratiaceans studied) (Fig. 30B). The left antapical horn is generally longer. The cingulum is not always as well pronounced as the original description suggests.

Imbatodinium exiguum (Alberti) comb. nov.

Broomea exigua Alberti $1961: 26$, pl. 5, fig. 14. Batioladinium? exiguum (Alberti) Brideaux 1975:1240. Necrobroomea exigua (Alberti) Wiggins 1975:111.

Imbatodinium gochtii (Alberti) comb. nov.

Broomea gochtii Alberti 1961:27, pl. 5, figs. 8-10. Necrobroomea gochtii (Alberti) Wiggins 1975:111.

\section{Imbatodinium jaegeri (Alberti) comb. nov.}

Broomea jaegeri Alberti 1961:26, pl. 5, figs. 1-7. Batioladinium jaegeri (Alberti) Brideaux 1975:1240, figs. 1-3.

Necrobroomea jaegeri (Alberti) Wiggins 1975:111.

\section{Imbatodinium longicornutum (Alberti) comb. nov.}

Fig. 32E

Broomea? longicornuta Alberti 1961:27, pl. 5, figs. 18-21.

Batioladinium longicornutum (Alberti) Brideaux 1975: 1240.

Necrobroomea longicornuta (Alberti) Wiggins 1975:111.

\section{Imbatodinium micropodum (Eisenack and Cookson) comb. nov. \\ Fig. 32A, D}

Broomea micropoda Eisenack and Cookson 1960:7, pl. 2, figs. 8, 9.

Butioladinium micropodum (Eisenack and Cookson) Brideaux 1975: 1240 .

Necrobroomea micropoda (Eisenack and Cookson) Wiggins 1975:111. 
Imbatodinium pelliferum (Alberti) comb. nov.

Figs. 18, 33A-D

Broomea pellifera Alberti $1961: 26$, pl. 5, figs. 11-13. Barioladinium? pelliferum (Alberti) Brideaux 1975:1240.

\section{Remarks}

We do not agree with Wiggin's treatment of "Broomea" pellifera as a junior synonym of "Broomea" micropoda. The ornament of " $B$ " micropoda is "coarsely and closely granular" (Eisenack and Cookson 1960:7) whereas ornament of " $B$ " pellifera is a short "fur-like" cover of densely arranged thin hairs (Alberti 1961; our own observations).

I. pelliferum exhibits faint sutural ornament under interference contrast illumination with tabulation of $4^{\prime}, 2 \mathrm{a}$, $6^{\prime \prime}, 6 \mathrm{c}, 6^{\prime \prime}$ ', ?p, ?"' ", ?s.

\section{Imbatodinium sp.}

Fig. 32B, F

\section{Description}

Elongated proximate dinoflagellate cyst with a long apical horn, and two short antapical horns of which one (left) is longer. Usually no tabulation indicated except by the outline of the archeopyle suture, which is asymmetrical suggesting a (4A2I) archeopyle. Surface finely reticulate, diameter of lumina $0.1-0.5 \mu \mathrm{m}$. Size: $89 \mu \mathrm{m}$.

\section{Remarks}

Positive identification under the light microscope is difficult. This species appears similar to $I$. micropoda; the surface ornament, visible only under SEM, is the sole difference. This species has been identified only from the Aptian of Germany (KBT $48.5 \mathrm{~m}$, Peine).
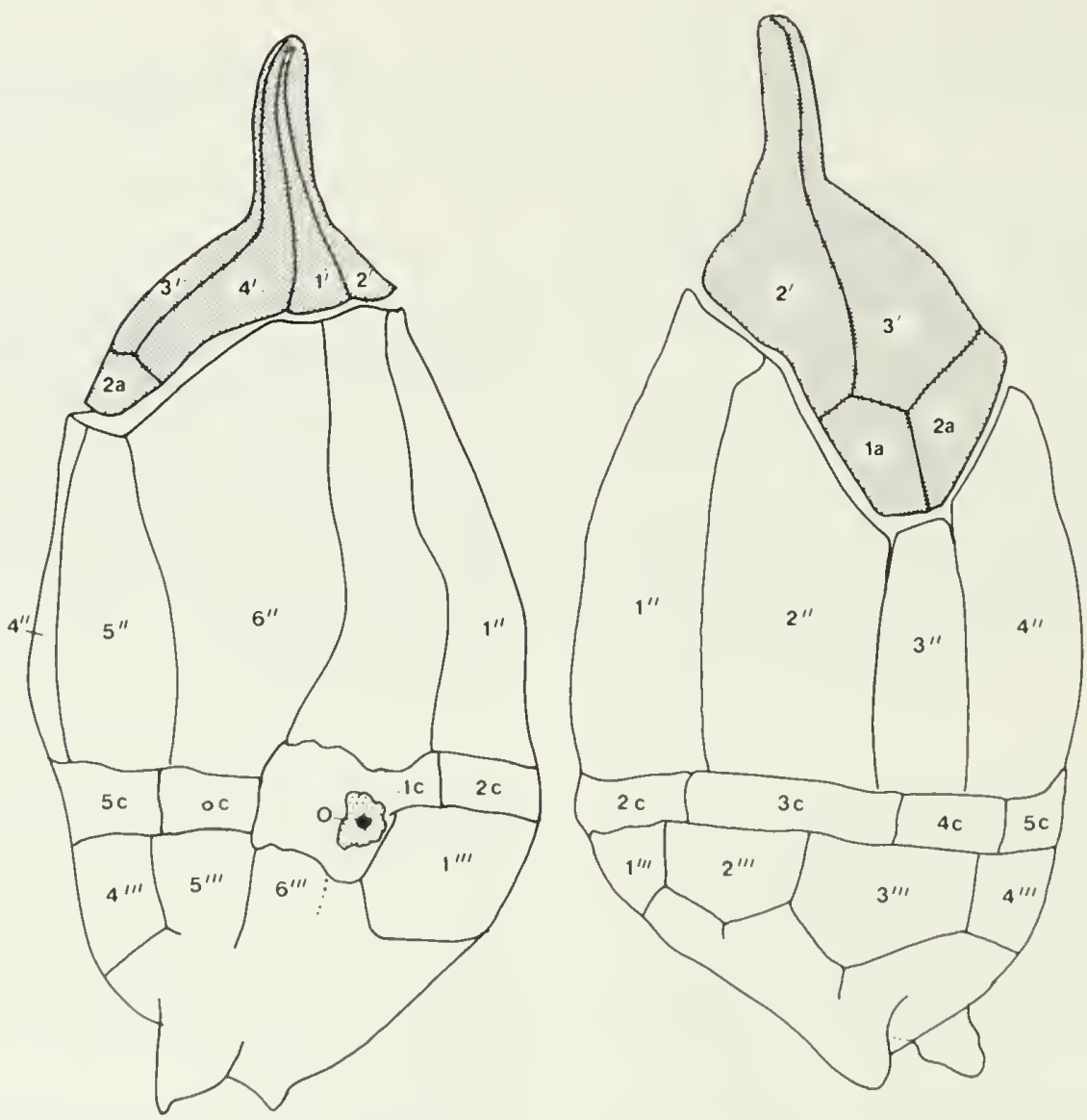

Fig. 18 Imbutodinium pelliferum (Alberi) comb. nov., showing tabulation and archeopyle. Tabulation: 4', 2a, 6" , 6c, 6" ', ?p, ?" ", ?s; archeopyle (4A2I). O: omphalos. 
Odontochitina Deflandre emend. Davey 1970

Odontochirina Deflandre 1935:234.

Odontochirina Deflandre emend. Davey 1970:354.

\section{Type Species}

Odonochisinu operculara (O. Wetzel) Deflandre and Cookson 1955.

\section{Odontochitina operculata (O. Wetzel) Deflandre and Cookson 1955}

Fig. $40 \mathrm{~A}$

Cerafium operculurum O. Wetzel 1933:170, pl. 2, figs. $21,22$.

Odontochirina silicorum Deflandre 1935:234, pl. 9, figs. $8-10$.

Odontochirina operculara (O. Wetzel) Deflandre and Cookson 1955:291, pl. 3, figs. 5, 6 .

\section{Remarks}

The asymmetrical archeopyle suture suggests pseudoceratiacean affinity and an (AI) archeopyle.

\section{Odontochitina nuda (Gocht) comb. nov.}

Pseudoceratium? nudum Gocht 1957: 168, pl. 18, figs. 3, 4,6 .

\section{Remarks}

This species is transferred to Odontochisina because of its smooth periphragm and its cavate nature.

\section{Pseudoceratium Gocht emend.}

Pseudoceratium Gocht 1957:166.

\section{Type Species}

Pseudoceratium pelliferum Gocht 1957.

\section{Emended Diagnosis}

Dorsoventrally flattened proximate dinoflagellate cysts of asymmetrical triangular shape with three long horns in apical, antapical, and postcingular positions. A fourth horn (left postcingular) is occasionally weakly developed. Ornament apteate, consisting of peni- and infratabular elements. Tabulation traces occasionally apparent, for- mula: 4', 2a, 6", 5-6c, 6" ', 1"' ", ?3-6s. Archeopyle (4A21), operculum occasionally attached ventrally.

\section{Remarks}

The genus is emended to have apteate ornament, and intercalary plates. Odontochirina is smooth and cavate. The sole difference between Pseludocerarium and Aptea is the length of the horns which are reduced in Apte's. If this feature should prove not to justify generic separation, Aptea would become a junior synonym. Muderongia and Phoberocysta approach bilateral symmetry by exhibiting two distinct postcingular horns.

\section{Pseudoceratium pelliferum Gocht emend.}

Figs. 35F, 37B-E

Pseudoceratium pelliferum Gocht 1957: 166, pl. 18, figs. $1,2$.

\section{Remarks}

The species is here emended to account for the presence of two anterior intercalary plates, which are included in the operculum; archeopyle (4A2I); ornament apteate, short and numerous penitabular and intratabular processes, the latter possibly following latent sutures between fused plates (Fig. 37C, E). The surface between the processes is finely corrugated-reticulate (Fig. 37D). Horn positions correspond to one each in apical, left antapical, and right postcingular positions. A slight left postcingular bulge (Fig. 37B) possibly indicates a fourth horn.

\section{Suborder Hystrichosphaeridiineae \\ Family Batiacasphaeraceae fam. nov. pro \\ Canningiaceae Sarjeant and Downie \\ Type Genus \\ Batiacasphaera Drugg emend.}

\section{Family Diagnosis and Remarks}

A new name is desirable for the family Canningiaceae because Canningia has been transferred to the family Pseudoceratiaceae. Batiacasphaeraceae is a substitute for the Canningiaceae and retains the original diagnosis for Canningiaceae Sarjeant and Downie (1974) that includes genera with an A-archeopyle (Norris, 1978b). Canningia, because it has an $\mathrm{AI}$ archeopyle is transferred to the family Pseudoceratiaceae. The logogram for the Batiacasphaeraceae is $\operatorname{Pr}, A$, non, pcin. 
Batiacasphaera Drugg 1970:813, fig. 6a-b.

Batiacasphaera Drugg emend. Morgan 1975:161.

Senusidinium Sarjeant and Stover 1978.

\section{Type Species}

Batiacasphaera compta Drugg 1970.

\section{Remarks}

The genus is emended to include the remaining species of "Tenua" after the holotype of "Tenua" was transferred to Crclonephe lium (Davey, in press); it also includes those species which were removed from Canningia because they lack indented antapices and asymmetrical archeopyle sutures (see p. 00; Drugg, 1970:813; Morgan, 1975:161). Cassidium Drugg 1967 is very similar to Batiacasphaera and could possibly take priority if the exact type or archeopyle, i.e. presence or absence of intercalaries, could be established. Drugg's illustration (1967:pl. 3, fig. 15) suggests a pseudoceratiacean operculum (with two intercalaries). Besides species transferred below, the genus contains the following:

\section{Batiacasphaera compra Drugg 1970 \\ B. baculata Drugg 1970 \\ B. macrogranulata Morgan 1975.}

Norvick and Burger (1976) suggested possible synonymy of Batiacasphaera with Membranosphaera Samoilovich 1961 ex. Norris and Sarjeant 1965, as Drugg's (1967, 1970) diagnosis of both genera overlap. At present Membranosphaera differs by small size and a ventrally attached operculum, which bears a pronounced sulcal tongue. Both criteria are probably of subgeneric significance. Examination of the holotype specimen is necessary to determine whether a periphragm is present. This feature would differentiate it from Batiacasphaera.

Most of the species transferred below to Batiacasphaera were included in the genus Sentusidinium Sarjeant and Stover (1978), which circumscribes the same species as Batiacasphaera as emended above. Characters within the morphological group of proximate cysts with a spherical body and a (4A) archeopyle are few and at present do not justify generic separation. However, the complex is probably polyphyletic, as affinities with lithodiniacean (Jurassic forms) and areoligeracean (Cretaceous and later forms) cysts are indicated. Further research might reveal discriminating characters.

The following species are transferred to Batiacasphaera.
Canningia circularis Cookson and Eisenack 1971:219, pl. 8 , fig. 6 .

\section{Batiacasphaera capitata (Cookson and Eisenack) comb.} nov.

Hystrichosphaeridium capitatum Cookson and Eisenack 1960:252, pl. 39, fig. 9.

Tenua capitata (Cookson and Eisenack) Gitmez and Sarjeant 1972:189, pl. 1, figs. 11-12.

\section{Batiacasphaera echinata (Gitmez and Sarjeant) comb. nov.}

Tenua echinata Gitmez and Sarjeant 1972:190, pl. 1, figs. 1-9.

\section{Batiacasphaera minor (Cookson and Hughes) comb. nov.}

Canningia minor Cookson and Hughes 1964:43, pl. 8, figs. $1-3,5$.

\section{Batiacasphaera pilosa (Ehrenberg) comb. nov.}

Xanthidium pilosum Ehrenberg 1843:61-63.

Xanthidium pilosum Ehrenberg 1843-Ehrenberg 1854, pl. 37, figs. 8, 4.

Ovum Hispidum (Xanthidium) pilosum (Ehrenberg) Lohman 1904:21-25.

Hystrichosphaera pilosa (Ehrenberg) O. Wetzel 1933:43, pl. 4, fig. 23.

Hystrichosphaeridium pilosum (Ehrenberg) Deflandre 1937:79.

Baltisphaeridium pilosum (Ehrenberg) Sarjeant 1960: pl. 13, figs. 11, 12; pl. 14, fig. 11.

Cleistosphaeridium pilosum (Ehrenberg) Davey et al. 1966: 170 .

Tenua pilosa (Ehrenberg) Sarjeant 1968:231, pl. 2, fig. 7.

\section{Batiacasphaera ringnesii (Manum and Cookson) comb.} nov.

Canningia ringhesii Manum and Cookson 1964:15, pl. 2, fig. 10. 
Batiacasphaera rioulti (Sarjeant) comb. nov.

Tenua rioulti Sarjeant 1968:231, pl. 1, figs. 12, 22; pl. 2, figs. $1,2,4$.

\section{Batiacasphaera rotundata (Cookson and Eisenack) comb. nov.}

Canningia rotunduta Cookson and Eisenack 1961:72, pl. 12 , figs. $1-5$.

\section{Batiacasphaera taugourdeaui (Varma and Dangwal) comb. nov.}

Tenua taugourdeaui Varma and Dangwal 1964:68, pl. 2, fig. 9.

\section{Batiacasphaera torulosa (Davey and Verdier) comb. nov.}

Canningia torulosa Davey and Verdier 1973:180, pl. 1, figs. $2,5,8$.

Batiacasphaera verrucosa (Sarjeant) comb. nov.

Tenua verrucosa Sarjeant 1968:232, pl. 1, fig. 17; pl. 2, figs. 3,6 .

\section{Batiacasphaera villersense (Sarjeant) comb. nov.}

Tenua villersense Sarjeant 1968:231, pl. 1, fig. 16; pl. 2, figs. $5,10$.

Family Areoligeraceae Evitt emend. Sarjeant and Downie

Cyclonephelium Deflandre and Cookson emend.

Cyclonephelium Deflandre and Cookson 1955:285.

Tenua Eisenack 1958:410.

Cyclonephelium Deflandre and Cookson emend. Cookson and Eisenack 1962:493.

Cyclonephelium Deflandre and Cookson emend. Williams and Downie 1966:223.

\section{Type Species}

Cyclonephelium distinctum Deflandre and Cookson 1955 (illustrated herein, Figs. 33E, 40C).

\section{Emended Diagnosis}

Dorsoventrally flattened proximate dinoflagellate cysts. Outline symmetrical, subeircular to ovoidal, occasionally slightly asymmetrical. Apex often bulges out into a short blunt apical horn. No hypotractal horns present. Variable apteate ornament consisting of capitate spines or baculae which may or may not fuse distally and/or proximally. The intra- and penitabular ornament is pronounced in the circumferential area. In the ventral and dorsal areas the ornament is reduced or lacking. Tabulation formula: $4^{\prime}$, 6", 5-6c, 6"' ', 1p, 1" "'; archeopyle (4A).

\section{Remarks}

This genus is now restricted to forms with apteate ornament. The symmetrical shape of the archeopyle does not suggest the presence of intercalary plates, thus separating the genus from all pseudoceratiacean genera. It is not chorate as the emendation by Davey et al. (1966) suggested. Chorate species of $C y c l o n e p h e l i u m$ have been transferred recently to the new genus Glaphyrocysta Stover and Evitt 1978. The type species of Tenua ( $T$. hystrix Eisenack 1958) is synonymous with Cyclonephelium (Davey, in press). All other species previously attributed to Tenua have evenly distributed and sometimes dense apteate ornament, and are transferred to Batiacasphaera Drugg 1970.

The following species accord with the emended diagnosis:

Cyclonephelium compactum Deflandre and Cookson 1955

C. areolatum Cookson and Eisenack 1960

C. clathromarginatum Cookson and Eisenack 1962

C. densebarbatum Cookson and Eisenack 1960

C. distinctum Deflandre and Cookson 1955

C. hughesii Clarke and Verdier 1967

C. hystrix (Eisenack) Davey (in press)

C. membraniphorum Cookson and Eisenack 1962

C. paucimarginatum Cookson and Eisenack 1962

C. paucispinum Davey 1969

?C. vannophorum Davey 1969

C. vitilare Cookson 1965.

The emendation separates two stratigraphically different complexes, since Cyclonephelium is generally restricted to the Cretaceous and Glaphyrocysta to the Upper Cretaceous and Tertiary. 


\section{Summary and Conclusions}

1. Upper Triassic to Lower Jurassic cysts examined exhibit primitive suessioid characters such as complex tabulation and disintegration archeopyles. Noricysta and Dapcodinium are emended.

2. New genera ancestral to the pareodiniaceans are proposed from the Lower to Middle Jurassic of Arctic Canada (Phallocysta, Susadinium, Dodekovia). They are compared with genera known from this interval and placed in an evolutionary lineage with ancestral suessioid forms.

3. Pareodiniacean and pseudoceratiacean genera from the Upper Jurassic to Lower Cretaceous of Arctic Canada and northwest Germany are reviewed and reinvestigated, and a close phylogenetic relationship is proposed. Several genera are emended: Paragonyaulacysta, Aptea, Canningia, Imbatodinium, Muderongia, Pseudoceratium, Batiacasphaera, Cyclonephelium, Komewiaia.

4. Both pareodiniacean and pseudoceratiacean genera have intercalary plates and differ principally in the mode of archeopyle formation: I in the former and (AI) in the latter. The tabulation formula for both families is $4^{\prime}, 2-3 a, 6^{\prime \prime}, 5-6 c, ? 6-7^{\prime \prime}$ ', ? $1 \mathrm{p}, \mathrm{l}^{\prime \prime}$ '".

5. Horn development in the Pseudoceratiaceae has phylogenetic significance but may also be related to ecological factors such as water temperature.

6. Archeopyle formation is closely related to the imbrication (Gocht and Netzel, 1976) of plate margins; the mid-dorsal keystone position of the archeopyle has essentially not changed since the Triassic and is probably homologous in most families. Apparent differences are due to Kofoidian plate nomenclature.

7. Different archeopyle types are determined by the strength of adcingular lap-joints and the state of fusion between neighbouring plate series.

8. Sequential lineages are documented explaining all major archeopyle types (I, AI, A, AIP, P) within the Rhaetogonyaulacineae from a common Triassic stock. The possible evolutionary steps are outlined below:

(a) Possible evolution of proximate dinoflagellate cysts from Micrhystridium-type achritarchs with disintegration archeopyles and suessioid tabulation within the Triassic.

(b) Radiation of suessioid proximate cysts in the Late Triassic, i.e. Rhactogonyaulax, Sverdrupiella, Heihergella, Noricysta, Suessia.

(c) Through plate fusion the archeopyle became more stabilized in position in cysts such as Dapcodinium and Comparodinium in the Early Jurassic.

(d) Through further plate fusion the Phallocystaceae evolved with a stabilized $3 I$ archeopyle and an intercalary series of 4-5 plates, in the late Early and early Middle Jurassic.

(e) The evolution of the Pareodiniaceae from Phallocysta through Glomodinium with a 3I archeopyle and later reduction to 2I in Pareodinia in the Middle Jurassic and II as in Broomea in the Middle to Late Jurassic.

(f) The development of antapical horns in the Pareodiniaceae as in Komewuia during the Late Jurassic.

(g) Fusion of the 2a to the apical series thus forming a (4A2I) archeopyle of the Pseudoceratiaceae such as Imbatodinium in the late Late Jurassic and early Early Cretaceous.

(h) Elaboration in horn number and length within the Pseudoceratiaceae in the Early Cretaceous.

(i) Further fusion of the apical and intercalary plates into one apical series forming the 4A archeopyle of some members of the Batiacasphaeraceae such as Cyclonephelium in the Early Cretaceous.

(j) Possible formation of the precingular archeopyle through fusion of the dorsal intercalary plates with the dorsal precingular plates as in Dodekovia (3I3P) leading to the Gonyaulacystineae in the Middle Jurassic.

(k) Possible evolution of peridinioid cysts through pseudoceratiacean cysts such as Muderongia simplex involving a shift in structure towards symmetry.

9. The supra-generic classification of Norris (1978a, b) closely parallels our phylogenetic concepts; some taxa, however, have been reassigned. Two new families are proposed: Phallocystaceae and Batiacasphaeraceae. The family Pseudoceratiaceae is emended and transferred to the suborder Rhaetogonyaulacineae. The families Rhaetogonyaulacaceae and Pareodiniaceae are emended.

\section{Acknowledgements}

We thank the following for critically reading the manuscript and for their helpful suggestions: W.W. Brideaux, J. Bujak, R.J. Davey, W.R. Evitt, H. Gocht, H. Netzel, G. Norris, L.E. Stover, J.P. Verdier, W. Wille, and two anonymous reviewers. P.B. O'Donovan assisted with photography and G. Gomolka assisted with scanning electron microscopy. Appreciation is expressed to Elf Oil Co. (Aquitane Canada Ltd.), Mobile Oil Canada Ltd., and the Geological Survey of Canada who donated samples. Work by G. Dörhöfer was done during tenure of a postdoctoral fellowship funded by a National Research Council Negotiated Development Grant to the Department of Geology, University of Toronto. E.H. Davies received research assistantships from research agreements from Energy, Mines and Resources Canada and grants-in-aid from the National Research Council of Canada (all to G. Norris, Principal Investigator), during completion of his Ph.D. requirements in the Department of Geology, University of Toronto. 


\section{Literature Cited}

1971 Cretaceous microplankion from Eyre No. 1 Bore Core 20. Western Australia. Proceedings ol the Royal Society of Victorial $84: 217-226$

ALBERT1. G

1961 Zur Kenntnis mesozorscher und alttertiärer Dinotlagellaten und Hystrichosphaerideen von Nord- und Mitteldeutschland, sowic einigen anderen europäischen Gebieten. Palacontographica (Abt. A) 116:1-58.

BENEDEK. P V

1972 Phỵtoplankton aus dem Mittel- und Oteroligozän von Tönisberg (Niederrheingebiet). Palacontographica (Abt. B) $137: 1-71$

BERTHOLD, $" \mathrm{~L}$ ' H GOCHT, C H HEMLEBEX. and H NFTZEL.

1976 Cytologische und öhologische Aspekte der Morphogenese und Siruktur rezenter und fossiler ProtistenSkelette. Zentralblatt für Geologie und Paläontologie, Heft $5 / 6: 325-338$

BIBBY, B T and J D DODGE

1972 The encystment ol a freshwater dinoflagellate: a light and electron-microscopical study. British Phycological Journal $7: 85-100$

BOLTOISKOY. A

1973 Formacion del arqueopilo en tecas de dinoflagellados. Revista Española de Micropaleontologia 5:81-98

BRIDEALX, WA

1975 Taxonomic note: redefinition of the genus Broomea and its relationship to Batioladinium gen. nov. (Cretaceous). Canadian Journal of Botany 53:1239-1243.

BRIDEALX: $W$ and M.J. FSHER

1976 Upper Jurassic - Lower Cretaceous dinoflagellate assemblages from Arctic Canada. Geological Survey of Canada, Bulletin 259:1-53.

BROOKS. J P. R GRANT. M MUIR, P. VAN GUZEL, and G. SHAW

1971 Sporopollenin. London, Academic Press. 718 pp.

BUJAK. J P. and M.J. FISHER

1976 Dinoflagellate cysts from the Upper Triassic of Arctic Canada. Micropaleontology 22:44-70.

CLARKE. R F A and J P VERDIER

1967 An investigation of microplankton assemblages from the Chalk of the Isle of Wight, England. Koninklijke Nederlandse Akademie van Wetenschappen, Afdeeling Natuurkunde, Verhandelingen, Series 1, 24(3): 1-96

COOKSON, IC and A EISEVACK

1958 Microplankton from Australian and New Guinea Upper Mesozoic sediments. Proceedings of the Royal Society of Victoria $70: 19-78$

1960 Upper Mesozoic microplankton from Australia and New Guinea. Palaeontology 2:243-261

1961 Upper Cretaceous microplankton from the Belfast No. 4 Bore, south-western Victoria. Proceedings of the Royal Society of Victoria 74:69-76.

1962 Additional microplankton from Australian Cretaceous sediments. Micropaleontology $8: 485-507$

1968 Microplankton from two samples from Gingin Brook No. 4 Borehole, Western Australia. Journal of the Royal Society of Western Australia 51:110-122

1970 Cretaceous microplankton from the Eucla Basın, Western Australia Proceedings of the Royal Society of Victoria $83: 137-157$.
Coxisox $1 \mathrm{C}$ and NF HUGHLS

1964 Microplankton from the Cambridge Greensand (midCretaceous). Palacontology 7:37-59.

CRAHFORD, R M and J D DODGL

1971 The dinollagellate genus Woloszinskia. II The line structure of W. coronata. Nova Hedwigia 22:699-719.

DAYEY. R J

1969 Non-calcareous microplankton lirom the Cenomanian of England, northern France and North America, Part 1. Bulletin of the British Museum (Natural History) Geology 17: 103-180.

1970 Non-calcareous microplankton from the Cenomanian of England, northern France and North America, Part 11. Bulletin of the British Museum (Natural History) Geology $18: 333-397$

1974 Dinotlagellate cysts from the Barremian of the Speeton Clay. England. Birbal Sahni Institute of Palaeobotany, Special Publication 3:41-75

In press Marine Cretaceous palynology of Site 361, DSDP 40, olf Southwestern Africa. Initial Reports of the Deep Sea Drilling Project 40.

DAVEY, R.J., C. DOWNIE, W. A S. SARJEANT, and G.L. WILLIAMS

1966 Studies on Mesozoic and Cainozoic dinoflagellate cysts. Bulletin of the British Museum (Natural History) Geology, Suppl. 3:1-248.

DAVEY, R.J. and J P. VERDIER

1974 Dinoflagellate cysts from the Aptian type sections at Gargas and La Bédoule, France. Palaeontology 17:623-653.

DAVIES, E.H

1979 Jurassic and Lower Cretaceous dinoflagellate cysts of the Sverdrup Basin, Arctic Canada: taxonomy, biostratigraphy, chronostratigraphy. Ph.D. Thesis, University of Toronto.

DEFLANDRE. G

1935 Considérations biologiques sur les microorganismes d'origine planctonique conservés dans les silex de la craie. Bulletin Biologique de la France et de la Belgique $69: 213-244$

1936 Microfossiles des silex crétacés. Première partie, Généralités, flagellés. Annales de Paléontologie $25: 151-191$

1937 Microfossiles des silex crétacés; Deuxième partie, Flagellés incertae sedis, hystrichosphaeridés, sarcodinés, organismes divers. Annales de Paléontologie 26:51-103.

1938 Microplancton des mers Jurassiques conservé dans les marnes de Villers-sur-Mer (Calvados); Étude liminaire et considérations générales. Travaux de la Station Zoologique de Wimereux 13:147-200.

1947 Sur quelques micro-organismes planctoniques des silex Jurassiques. Bulletin de l'Institut Océanographique de Monaco $921: 1-10$

DUILANDRE, G and I C. COOKSOS

1955 Fossil microplankton from Australian Late Mesozolc and Tertiary sediments. Australian Journal of Marine and Freshwater Research 6:242-313 
DODEKOVA. L.

1975 New Upper Bathonian dinoflagellate cysts from northeastern Bulgaria. Paleontologiya, Stratigrafiya i Litologiya $2: 17-34$.

DONN. W.L and D M SHAW

1977 Model of climate evolution, based on continental drift and polar wandering. Geological Society of America Bulletin $88: 390-396$.

DÖRHÖFER, G

1977a Biogeography of Mesozoic dinoflagellate cysts. Annual Report of the Negotiated Development Grant, University of Toronto, pp. 169-175.

1977b Principles of dinoflagellate cyst provincialism. Coloquio Internacional de Palinologia, Léon, Spain, Abstracts, p. 15.

In press Principles of dinoflagellate cyst provincialism: the Albian of the northern hemisphere. Marine Micropaleontology.

DRUGG, W:S

1967 Palynology of the Upper Moreno Formation (Late Cretaceous-Paleocene), Escarpado Canyon, Califomia. Palaeontographica (Abt. B) 120:1-71.

1970 Some new genera, species and combinations of phytoplankton from the Lower Tertiary of the Gulf Coast, U.S.A. Proceedings of the North American Paleontological Convention, 1969, pp. 809-843.

DURR G. and H NETZEL

1974 The fine structure of the cell surface in Gonvaulax polvedra (Dinoflagellata). Cellular Tissue Research 150:21-41.

DUXBURY, S.

1977 A palynostratigraphy of the Berriasian to Barremian of the Speeton Clay of Speeton, England. Palaeontographica (Abt. B) $160: 17-67$

EATON, G.L.

1976 Observations on the pattern of omament distribution in the fossil dinoflagellate cyst genus Cribroperidinium. Fourth International Palynological Conference, Lucknow, India, Abstracts, p. 45-46.

EHRENBERG. C G.

1843 Über einige Jura-Infusorien-Arten des Korallrags bei Krakau. Monatsberichte der Berliner Akademie der Wissenschaften : 61-63.

1854 Mikrogeologie. Leipzig. 486 pp.

EISENACK, A

1935 Mikrofossilien aus Doggergeschieben Ostpreussens. Zeitschrift für Geschiebeforschung 11:167-184.

1938 Eodinia pachvoheca n.g., n. sp., ein primitiver Dinoflagellat aus einem Kelloway-Geschiebe Ostpreussens. Zeitschrift für Geschicbeforschung 12:72-75.

1958 Mikroplankton aus dem norddeutschen Apt nebst einigen Bemerkungen über fossile Dinoflagellaten. Neues Jahrbuch lür Geologie und Paläontologie, Abhandlungen $106: 383-417$

1961 Einige Erörterungen über fossile Dinoflagellaten nebst Ubersicht über die zur Zeit bxkannten Gattungen. Neues Jahrbuch für Geologie und Paläontologie, Abhandlungen 112:281-324

1964 Erörterungen über einige Gattungen lossiler Dinollagellaten und über die Einordnung der Gattungen in das System. Neues Jahrbuch für Geologie und Paläontologie, Monatshefte $1964(6): 321-336$
EISENACK, A and I C. COOKSO:

1960 Microplankton from Australian Lower Cretaceous sediments. Proceedings of the Royal Society of Victoria $72: 1-11$.

EISENACK, A and KJELLSTROMM, G

1971 Katalog der fossilen Dinoflagellaten, Hystrichosphären und verwandten Mikrofossilien. Band 1. Dinoflagellaten, 2. Ergänzungslieferung. Stuttgart, E. Schweizerbart (Nägele U. Obermiller). 895 pp.

EVITT, W'R.

1961 Dapcodinium priscum n. gen., n. sp., a dinoflagellate from the Lower Lias of Denmark. Joumal of Paleontology 35:996-1002

1967 Dinoflagellate studies 11, the Archeopyle. Stanford University Publications, Geological Sciences 10 (3): 1-83.

EVITT, W R., J.K. LENTIN, M E. MILLLOUD. L.E. STOVER, and G.L. WTLLLAMS

1976 Dinoflagellate cyst terminology. Geological Survey of Canada, Paper 76-24:1-11.

FISHER, M.J. and J. BUJAK

1975 Upper Triassic palynofloras from Arctic Canada. Geoscience and Man 11:87-94.

GITMEZ, G.U. and W.A S SARJEANT

1972 Dinoflagellate cysts and acritarchs from the Kimmeridgian (Upper Jurassic) of England, Scotland and France. Bulletin of the British Museum (Natural History) Geology $21: 171-256$.

GOCHT, H

1957 Mikroplankton aus dem nordwestdeutschen Neokom (Teil 1). Paläontologische Zeitscheift $31: 163-185$.

1970 Dinoflagellaten-Zysten aus dem Bathonium des Erdölfeldes Aldorf (NW-Deutschland). Palaeontographica (Abt. B) $129: 125-165$.

1975a Neuuntersuchung von Eodiria pachvrheca Eisenack 1936 (Dinoflagellata, Oberjura). Neues Jahrbuch für Geologie und Paläontologie, Abhandlungen 148:12-32.

1975b Morphologie und Wandstruktur von Lirhodinia jurassica Eisenack 1935 (Dinoflagellata, Oberjura). Neues Jahrbuch für Geologie und Paläontologie, Monatshefte 1975 (6) : 343-359.

1976 Histrichosphaeropsis quasicribrata (O. Wetzel), ein Dinoflagellat aus dem Maastricht Nordeuropas. Neues Jahrbuch für Geologie und Paläontologie, Monatshefte 1976 (6) : $321-336$

GOCHT, $\mathrm{H}$ and $\mathrm{H}$ NETZEL

1974 Rasterelektronenmikroskopische Untersuchungen am Panzer von Peridinium (Dinoflagellata). Archiv für Protistenkunde $116: 381-410$

1976 Reliefstrukturen des Kreide-Dinoflagellaten Pulacoperidinium purophorum (Ehr.) in Vergleich mit Panzer-Merkmalen rezenter Peridimium-Arten. Neus Jahrbuch für Geologie und Paläontologie, Abhandlungen $152: 380-413$

HARLAND, K., S.J. MORBEY, and W.A.S SARJEANT

1975 A revision of the Triassic to lowest Jurassic dinoflagellate Rhaetogonvaulax. Palaeontology 18:847-864.

HERNGRELN, G I. $\mathrm{H}$ and $\mathrm{K} F, \mathrm{DE}$ BOLK

1974 Palynology of Rhactian, Liassic and Dogger strata in the eastern Netherlands. Geologie en Mijnbouw 53:343-368. 
HL'BER, $G$ and + NIPKOW

1923 Experimentelle Untersuchungen üter dic Entwichlung und Fombildung von Cerarium hurundinella O.f. Müller. Allgemeine Botanische Zeitschrift. Neue Folge 16:114 215.

IOAVIDES. N S G G STAIRIVOS. and C DOW VIE

1977 Kinmeridgian microplankton from Clavel's Hard, Dorset, England. Micrupaleontology $22: 43-478$

IRVIVG, E

1974 Latitude variation of the Canadian Arctic lslands during the Phanerozoic. In Aitken, J.D. and D.J. Glass, eds., Proceedings of the Symposium on the Geology of the Canadian Arctic, Geological Association of Canada and Canadian Society of Petroleum Geologists, Saskatoon, 1973. pp. 1-3

JOHNSOV. C.D and L Y HILLS

1973 Microplankton zones of the Savik Formation (Jurassic), Axel Heiberg and Ellesmere lslands, District of Franklin. Bulletin of Canadian Petroleum Geology $21: 179-218$

KOFOID, C.A

1909 On Peridinium steini Jörgensen, with a note on the nomenclature of the skeleton of the Peridinidae. Archiv für Protistenkunde $16: 25-47$

LENTIS. $J K$, and G L. WILLIAMS

1973 Fossil dinoflagellates: index to species and genera. Geological Survey of Canada, Paper 73-42:1-179.

1975 A monograph of fossil peridinoid dinoflagellate cysts. Bedford Institute of Oceanography, Report 75-16:1-237.

LOEBLICH. A R . III

1970 The amphiesma or dinoflagellate cell covering. Proceedings of the North American Paleontological Convention, 1969. pp. $867-929$

LOEBLICH, A R.J and A R LOEBLICH. III

1968 Index to the genera, subgenera, and sections of the Pyrrhophyta, 11. Journal of Paleontology 42:210-213.

LOHMA.N. H

1904 Eier und sogenannte Cysten der Plankton-Expedition Anhang: Cyphonautes. Kiel, Wissenschaftich Ergebnisse der Plankton-Expedition Humboldt-Stiftung (N.S.), 4: 162

MANC's, $S$ and I C COOKSON

1964 Cretaceous microplankıon in a sample from Graham Island, Arctic Canada, collected during the second "Fram" Expedition (1898-1902), with notes on microplankton from the Hassel Formation. Ellef Ringnes Island. Norske Videnskaps - Akademi i Oslo, MatematiskNaturvidenskapelig Klasse, Skrifter, Ny Serie 17:1-35.

MILLOLD. M.B.

1969 Dinoflagellates and acritarchs from some western European Lower Cretaceous type localities. In Brönnimann, P. and H.H. Renz, eds., Proceedings of the lst International Conference on Planktonic Microfossils, Geneva, 1967. $2: 420-434$

MORBEY, S

1975 The palynostratigraphy of the Rhaetian stage Upper Triassic in the Kendelbachgraben. Austria. Palaeontographica (Abt. B) 152:1-75.
WORGIAN, R

1975 Some larly. Cretaceous organic-walled microplankton froms the Great Australian Basin, Australia Journal and Proceedings of the Royal Society of New South Wales 108: $157-167$

MOKGI NKOTH, P

1966 Microfossilien und Konkretionen des nordwesteuropäischen Untereozän. Palaeontographica (Abt B) $119: 1-53$

1970 Dinotlagellate cysts from the Lias Delta of Lühnde/Germany. Neues Jahrbuch für Geologie und Paläiontologie, Abhandlungen 136:345-359

NEALE, $J W$ and $W$ A S. SARJEANT

1962 Microplankton from the Specton Clay of Yorkshire. Geological Magazine 99:439-458.

NORRIS, G

1978a Phylogeny and a revised supra-generic classification for Triassic-Quaternary organic-walled dinoflagellate cysts (Pyrrhophyta). Pan 1. Cyst terminology and assessment of previous classifications. Neues Jahrbuch für Geologic und Paläontologie, Abhandlungen 155:300-317.

1978b Phylogeny and a revised supra-generic classification for Triassic-Quaternary organic-walled dinoflagellate cysts (Pyrrhophyta). Part 2. Families and suborders of fossil dinoflagellates. Neus Jahrbuch für Geologie und Paläontologie, Abhandlungen 156:1-30.

NORRIS, $G$ and G. DORHÖFER

1976 Pericoelar openings in fossil Mesozoic-Cenozoic dinoflagellate cysts. Annual Report of the Negotiated Development Grant, University of Toronto, pp. 141-142.

NORRIS, G. and W.A S SARJEANT

1965 A descriptive index of genera of fossil Dinophyceae and Acritarcha. New Zealand Geological Survey, Paleontological Bulletin $40: 1-72$

NORVICK, M S and D. BURGLR

1976 Palynology of the Cenomanian of Bathurst 1sland, Northern Territory, Australia. Australia, Bureau of Mineral Resources, Geology and Geophysics, Bulletin 151:1-169.

POCOCK, S A.J

1962 Microfloral analysis and age determination of strata at the Jurassic-Cretaceous boundary in the western Canada Plains Palaeontographica (Abt. B) 111:1-95.

1972 Palynology of the Jurassic sediments of western Canada. Part 2. Marine species. Palaeontographica (Abt. B) $137: 85-153$.

SAMUILOVICH, S.R.

1961 In Samoilovich. S.R. and N.O. Mchedlishuili, Pyl'tsa ; spory Zapadnoi Sibiri Yura Paleosten. Leningrad, Vsesoiuznyi Neftianoi Nauchno-issledovatel'skii Geologoraz. vedochnyi Institut. Trudy, vyp. 177:1-657.

SARJEANT, W'A.S.

1960 Microplankton from the Corallian rocks of Yorkshire. Proceedings of the Yorkshire Geological Society 32:389-406.

1961 Microplankton from the Kellaways Rock and Oxford Clay of Yorkshire. Palaeontology 4:90-118

1962 Upper Jurassic microplankton from Dorset, England. Micropaleontology $8: 255-268$

1963 Fossil dinoflagellates from Upper Triassic sediments. Nature 199:353-354. 
1966 Further dinoflagellate cysts from the Speeton Clay (Lower Cretaceous). Bulletin of the British Museum (Natural History) Geology, Suppl. 3: 199-214.

1968 Microplankton from the Upper Callovian and Lower Oxfordian of Normandy. Revue de Micropaléontologie 10:221-242.

1970 The genus Spiniferites Mantell, 1850 (Dinophyceae). Grana 10:74-78.

1972 Dinoflagellate cysts and acritarchs from the Upper Vardekloft Formation (Jurassic) of Jameson Land, East Greenland. Meddelelser om Gronland 195 (4):1-69.

1975 Stratigraphic range charts of selected fossil dinoflagellates: Triassic and Jurassic dinoflagellates. American Association of Stratigraphic Palynologists, Contribution Series 4:51-64.

1976 English Jurassic dinoflagellate cysts and acritarchs: a reexamination of some type and figured specimens. Geoscience and Man 15:1-24.

SARJEANT, W A S. and L. E. STOVER

1978 Crclonephelium and Tenua, a problem in dinoflagellate cyst taxonomy. Grana 17:47-58.

SCHMITTER, R E

1971 The fine structure of Gonvaulax polyedra, a bioluminescent marine dinoflagellate. Journal of Cellular Sciences 9: 147-173.

SCHRANK. F VON P

1793 Mikroskopische Wahrnehmungen. Der Naturforscher $27: 26-37$.

SINGH, C.

1971 Lower Cretaceous microfloras of the Peace River area, northwestern Alberta. Research Council of Alberta, Bulletin $28(2): 301-542$.

STOVER, L.E. and W E. EVITT

1978 Analyses of pre-Pleistocene organic-walled dinoflagellates. Stanford University Publications, Geological Sciences 15: $1-300$.

THUSU, B

1977 Observations on the morphology of the dinoflagellate cyst Imbatodinium villosum Vozzhennikova from the Lower Cretaceous of Spitzbergen. Coloquio Internacional de Palinologia, Léon, Spain, Abstracts, p. 35.

VARMA, C.P. and A.K. DANGWAL

1964 Tertiary hystrichosphaerids from India. Micropaleontology $10: 63-71$.

\section{VOZZHENNIKOVA, T.F}

1965 Vvedenie $v$ izuchenie iskopaemykh peridineevykh vodorosley. [Introduction to the study of fossil peridinian algae]. Akademiya Nauk SSSR, Sibirskoye Otdeleniye, Institut Geologii i Geofiziki, Trudy. $156 \mathrm{pp}$.

1967 Iskopayemyye peridinei yurskikh, melovykhi paleogenovykh otlozheniy SSSR. [Fossil peridinians from Jurassic, Cretaceous, and Paleogene deposits of the USSR]. Akademiya Nauk SSSR, Sibirskoye Otdeleniye, Institut Geologii i Geofiziki, Tnudy. 347 pp

Microplankton, pollen, and spores from the Lower Jurassic in Britain. Micropaleontology 11:151-190.

1967 Fossil microplankton in deep-sea cores from the Caribbean Sea. Palacontology 10:95-123.
WALL. D and W R EVITT

1975 A comparison of the modern genus Ceratium Schrank. 1793, with certain Cretaceous marine dinoflagellates. Micropaleontology $21: 14-44$.

WARREN, I.S.

1967 Dinoflagellates and acritarchs from the Upper Jurassic and Lower Cretaceous rocks on the west side of the Sacramento Valley, California. Ph.D. Thesis, Stanford University. $409 \mathrm{pp}$.

WETZFL, $O$.

1933 Die in organischer Substanz erhaltenen Mikrofossilien des baltischen Kreide-Feuersteins mit einem sedimentpetrographischen und stratigraphischen Anhang. Palaeontographica (Abt. A) 78:1-110.

1961 New microfossils from Baltic Cretaceous flintstones. Micropaleontology $7: 337-350$.

WIGGINS. V.D

1973 Upper Triassic dinoflagellates from arctic Alaska. Micropaleontology $19: 1-17$.

1975 The dinoflagellate family Pareodiniaceae; a discussion. Geoscience and Man 11:95-115.

1976 Upper Triassic-Lower Jurassic dinoflagellates. American Association of Stratigraphic Palynologists, 9th Annual Meeting, Halifax, 1976, Abstracts, p. 29.

WILLE, $W$ and H. GOCHT

In press Dinoflagellaten aus dem Lias Südwestdeutschlands. Neues Jahrbuch für Geologie und Paläontologie, Abhandlungen.

WILLLAMS, G.L. and C DOWNIE

1966 Further dinoflagellate cysts from the London Clay, Bulletin of the British Museum (Natural History) Geology, Suppl. 3:215-236.

WILLIAMS, G L., W.A S. SARJEANT, and E.J. KIDSON

1973 A glossary of the terminology applied to dinoflagellate amphiesma and cysts and acritarchs. American Association of Stratigraphic Palynologists, Contribution Series 2: $1-222$. 


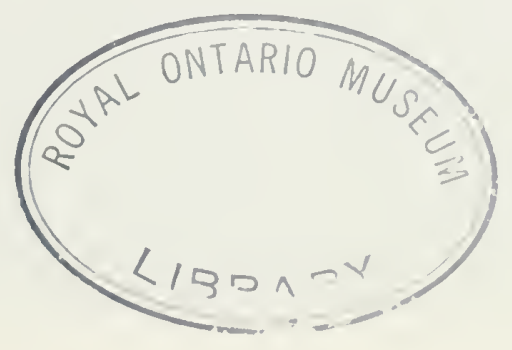


Unless otherwise stated, all illustrations of Figs. 19-40 were taken with interference contrast optics and enlarged to scale A on Fig. 38. See Fig. 38 for scale B.

Fig. 19 Scanning electron micrographs. All specimens are from sample Elf Jameson Bay C-31 JB 3300, Heiberg Fm., Arctic Canada.

A-G Sverdrupiella sabinensis Bujak and Fisher 1976.

A Ventral view $\times 730$, E Enlarged part of epitract, $\times 1460$. Note the archeopyle initiation at top left (white arrow) and mid-ventral claustrum (CL). ROM 36982.

B Left lateral view of epitract with initial disintegration archeopyle, $\times 1460$, D Enlarged portion of $\mathrm{B}, \times 3640$, ROM 36976.

C Right lateral view with mid-dorsal disintegration archeopyle. Note also the large claustrum (CL), $\times 1460$, ROM 36982.

F Detail of surface texture showing blunt spines in penitabular positions, $\times 3955$, ROM 36976.

G Apical view showing mid-dorsal initiation of disintegration archeopyle. Sulcal area indicated by $s . \times 1430$, ROM 36976. 


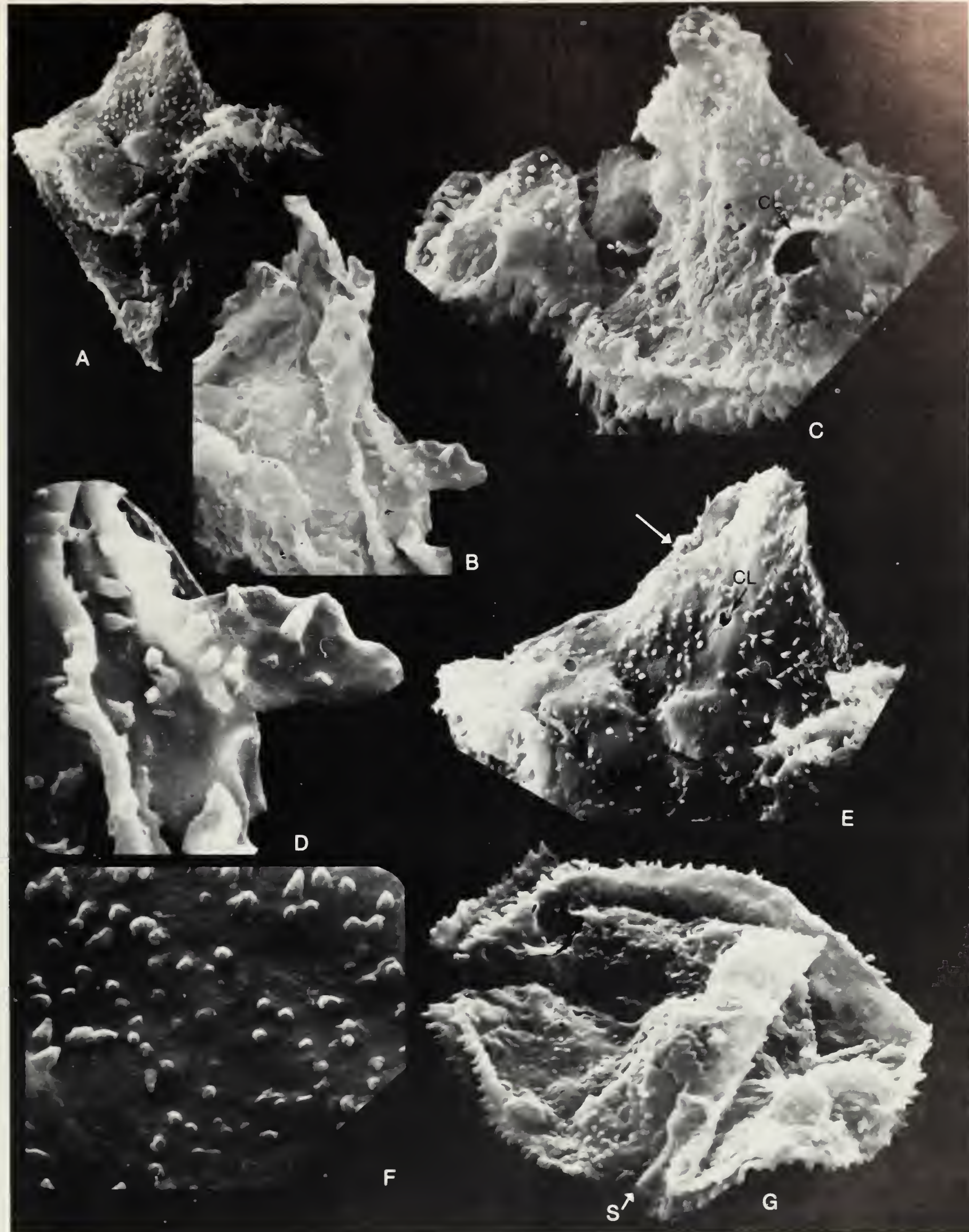


Fig. 20 A-B Heibergella salebrosacea Bujak and Fisher 1976 showing mid-dorsal initiation of disintegration archeopyle (arrow), Jameson Bay C-31, JB 3330, ROM 36956, 49.7/99.6, Heiberg Fm., Arctic Canada.

C-E Sverdrupiella sabinensis Bujak and Fisher 1976, showing disintegration archeopyle. Jameson Bay C-31, JB 3300; ROM 36595, 48.4/107.2, Heiberg Fm., Arctic Canada.

C Focus on apical plate series, which remained attached ventrally.

D Focus on intercalary and precingular plate series, showing penitabulary arranged spines; also note ventral claustruin (CL).

E Focus on narrow "protoprecingular" series (arrow). 

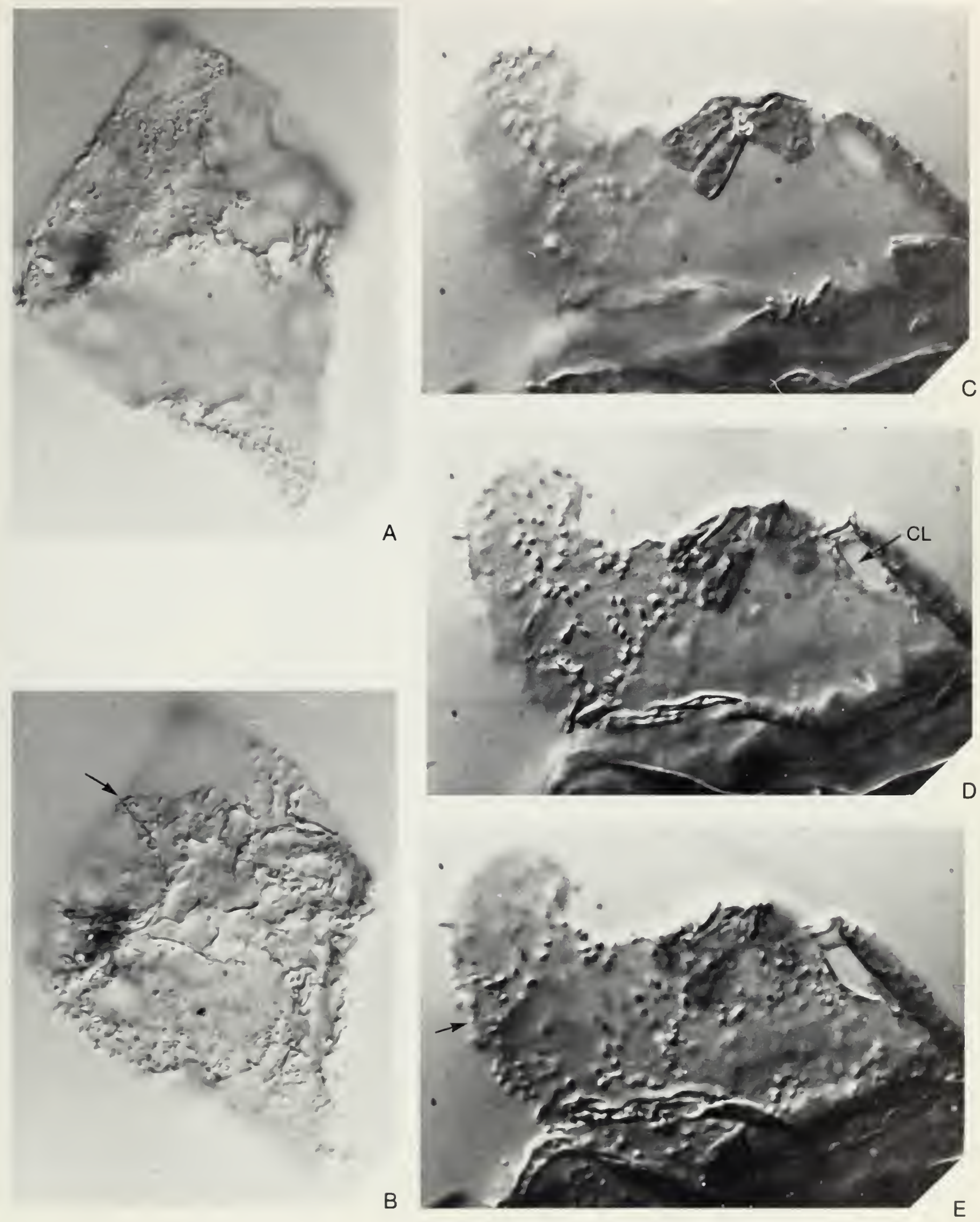
Fig. 21 Scanning electron photomicrographs. All specimens of Noricysı from sample SP 2541-45, Panarctic Sandy Point L-46, Heiberg Formation, Arctic Canada.

A, C "Micrhystridium" sp. exhibiting a disintegration archeopyle initiating in the mid-dorsal intercalary region, the keystone position. A $\times$ 2045. C × 1220. ED 1030-4, Savik Fm., Ellef Ringnes Island, Arctic Canada, ROM 36987.

B Noricysta fimbriata Bujak and Fisher 1975, showing complex tabulation. $\times 1580$, ROM 36983.

D Noricysta fimbriata, exhibiting initial archeopyle development. $\times 1225$, ROM 36985.

E Noricysta fimbriata, showing complex tabulation. $\times 2400$, ROM 36983.

F, G Noricista fimbriata. Detail of surface textures and sutural ornament. $\times 3640$. G $\times 2075$, ROM 36983 . 


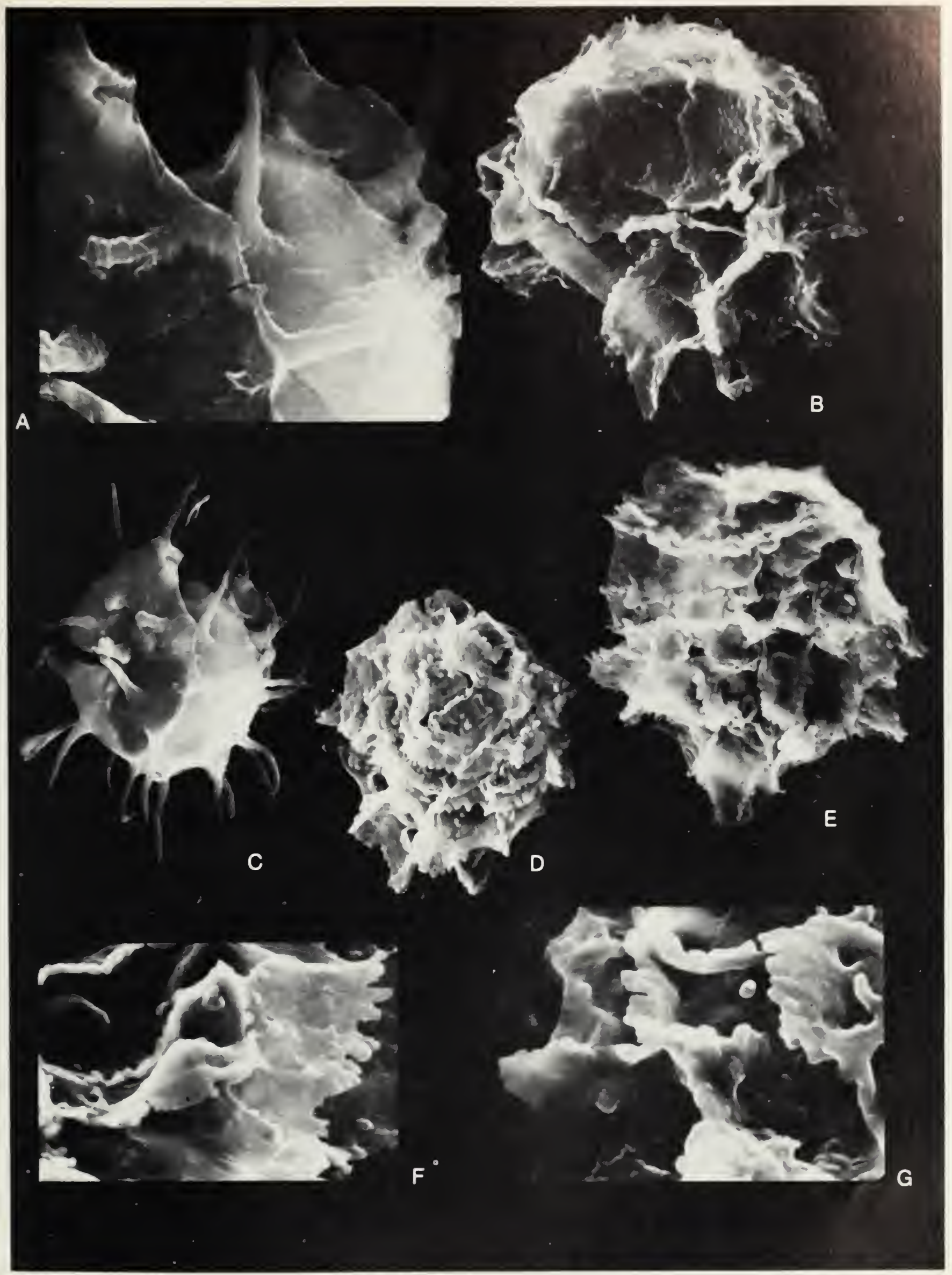


Fig. 22 A-B Noricysta fimbriata Bujak and Fisher 1976, showing disintegration archeopyle involving the apical series and initial breakdown of the precingular series. Panarctic Sandy Point L-46, SP 2541-45A, ROM 36964, 34.9/99.7, Heiberg Fm., Arctic Canada.

C Noricysta fimbriata Bujak and Fisher 1976, showing archeopyle initiation between the apical and intercalary plate series (arrow). Panarctic Sandy Point L-46, SP 2541-45A, ROM 36964, 44.6/103.2, Heiberg Fm., Arctic Canada.

D Dapcodinium sp. A, showing intercalary initiated disintegration archeopyle with the apical series remaining attached (A). Elf Jameson Bay C-31, JB 1950A, RoM 36552, 35.7/103.8, Savik Fm., Arctic Canada.

E-F Suessia swabiana Morbey 1975, antapical view showing complex tabulation and plates of the "protoprecingular" series (arrow), Panarctic Sandy Point L-46, SP 2541-45A, ROM 36964, 45.0/99.3, Heiberg Fm., Arctic Canada.

G, I Dapcodinium sp. B, showing disintegration archeopyle. The apical (A) and intercalary (I) series are indicated. Panarctic Sandy Point L-46, SP 1880, ROM 36965, 41.3/107.0. Wilkie Point Fm., Arctic Canada.

H Sverdrupiella sabinensis Bujak and Fisher 1976, showing disintegration archeopyle. Same specimen as Fig. 20, C-E. Scale B. Elf Jameson Bay C-31, JB 330-A, ROM 36596, 48.4/ 107.2, Heiberg Fm., Arctic Canada. 

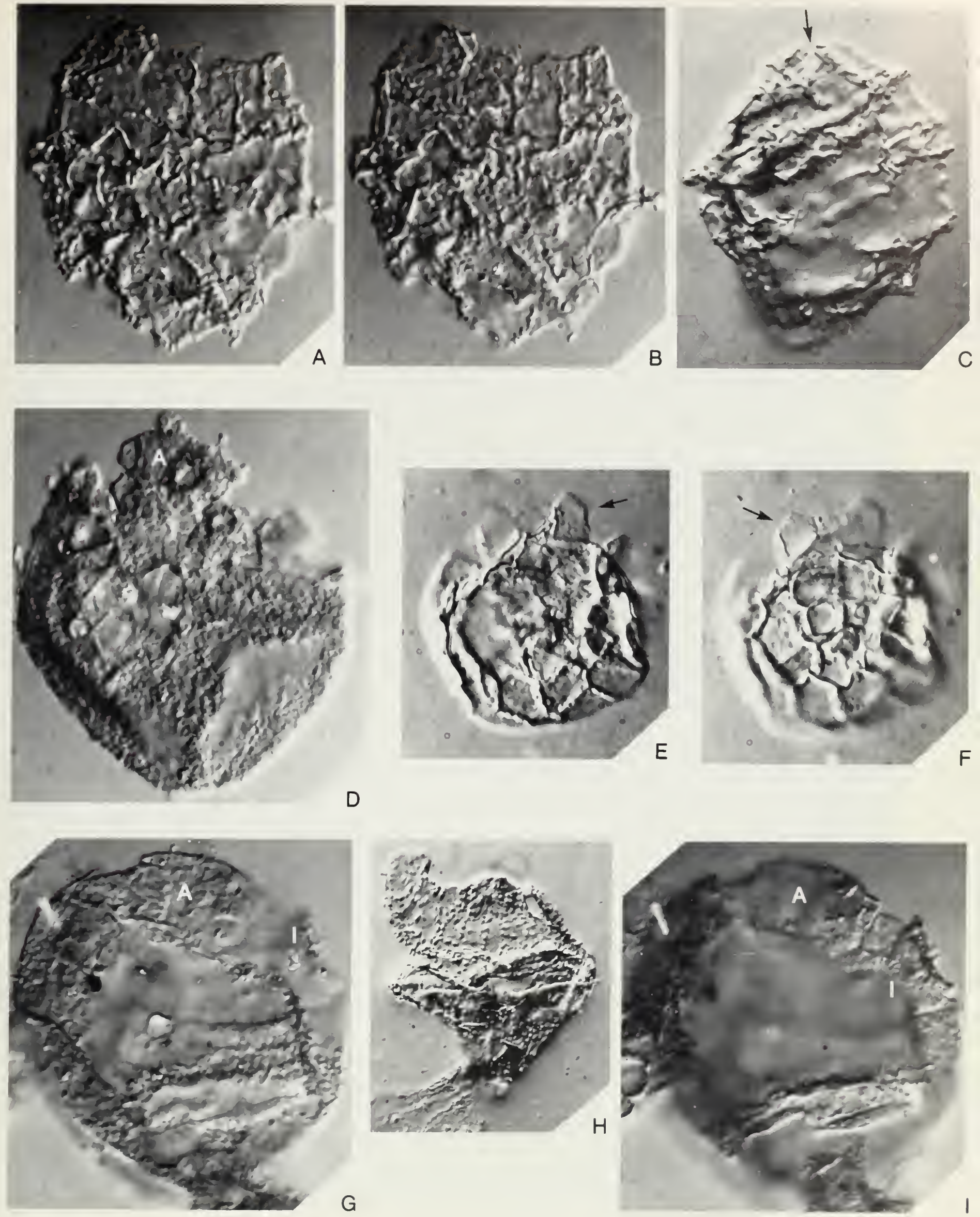
Fig. 23 Scanning electron photomicrographs.

A, C, D, F, G. Suessia swabiana Morbey 1975, Panarctic Sandy Point L-46, SP 2541-45, Heiberg Fm., Arctic Cánada.

A, C. Right lateral view showing initial archeopyle development. A $\times 3045, \mathrm{C} \times 1220$, ROM 36985. D $\times 1220$, ROM 36985 .

F Dorsal view showing advanced stages of the disintegration archeopyle. $\times 1220$, ROM 36985 .

G Right lateral view demonstrating plate fusion adcingularly. SP 2541-45A, × I460, ROM 36983.

B, E, H Dodekovia syzygia sp. nov. Savik Fm., Reindeer Peninsula, Ellef Ringnes Island. ED1030-4A, ROM 36992.

$\mathrm{B}, \mathrm{E}$ Left lateral view exhibiting precingular and intercalary plates separating from the archeopyle. $\mathrm{B} \times 3045$. $\mathrm{E}$ $\times 3045$.

H Right lateral view with 3P3I archeopyle. $\times 1220$. 

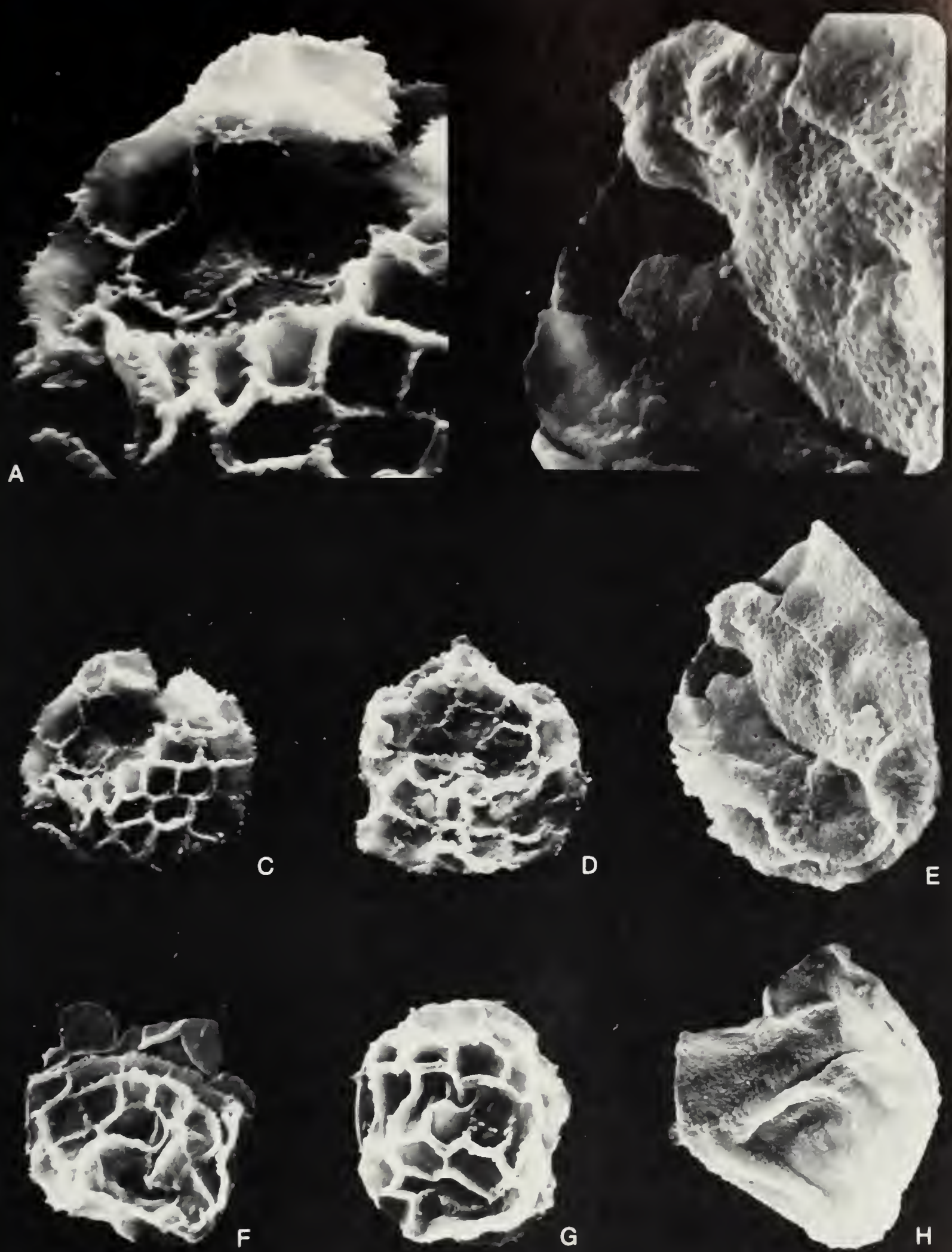
Fig. 24 A-C Noricysta fimbriata Bujak and Fisher 1976, showing sutural crests and folds. Note omphalos (OM) on B. Panarctic Sandy Point L-46, SP 2541-45/a, ROM 36964, 35.7/95.4, Heiberg Fm., Arctic Canada.

D, E, G Phallocysta eumekes sp. nov., lateral view showing epitractal tabulation and omphalos (OM). Elf. Wilkins E-60, WI 1410a, ROM 36452, 39.2/103.5.

F Susadinium scrofoides sp. nov., lateral view showing intercalary archeopyle. Reindeer Peninsula, ED1029-6a, ROM 36624, 44.3/105.2, Savik Fm., Arctic Canada.

H Susadinium scrofoides sp. nov., Panarctic Sandy Pt. L-46, SP 1935-40a, ROM 36966, 46.3/107.2, Savik Fm., Arctic Canada.

I Susadinium scrofoides sp. nov., holotype. Dorsal view showing intercalary archeopyle. Reindeer Peninsula, ED 1038-2a, ROM 36598, Savik Formation, Arctic Canada.

J Dapcodinium wapellense (Pocock) comb. nov., Elf Wilkins E-60, WI 2070a, ROM 36474, 43.2/102.1, Savik Fm., Arctic Canada.

K Susadinium scrofoides sp. nov., Elf Wilkins E-60, WI 1950a, ROM 36470, 47.3/105.0, Savik Fm., Arctic Canada. 

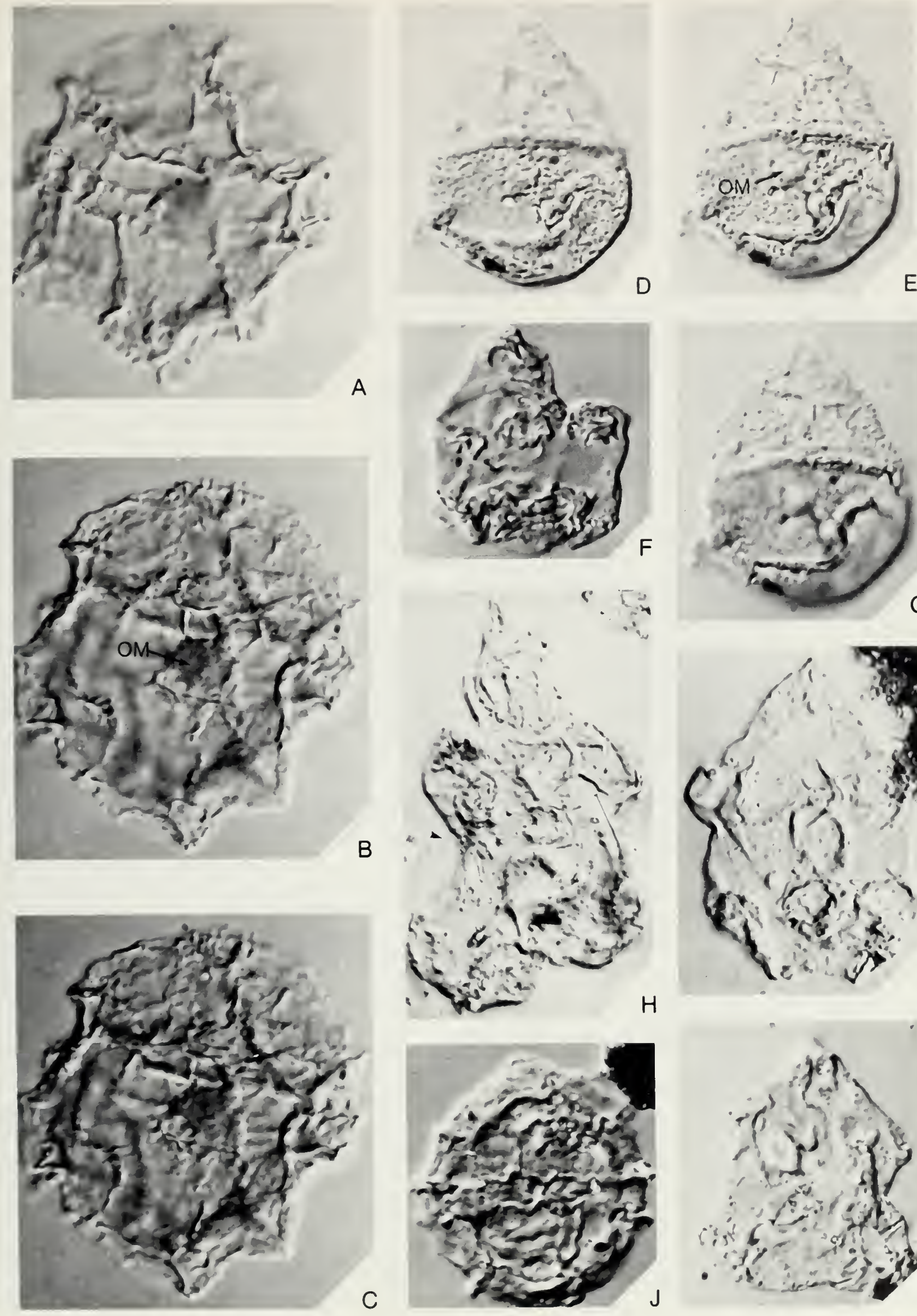

A

E
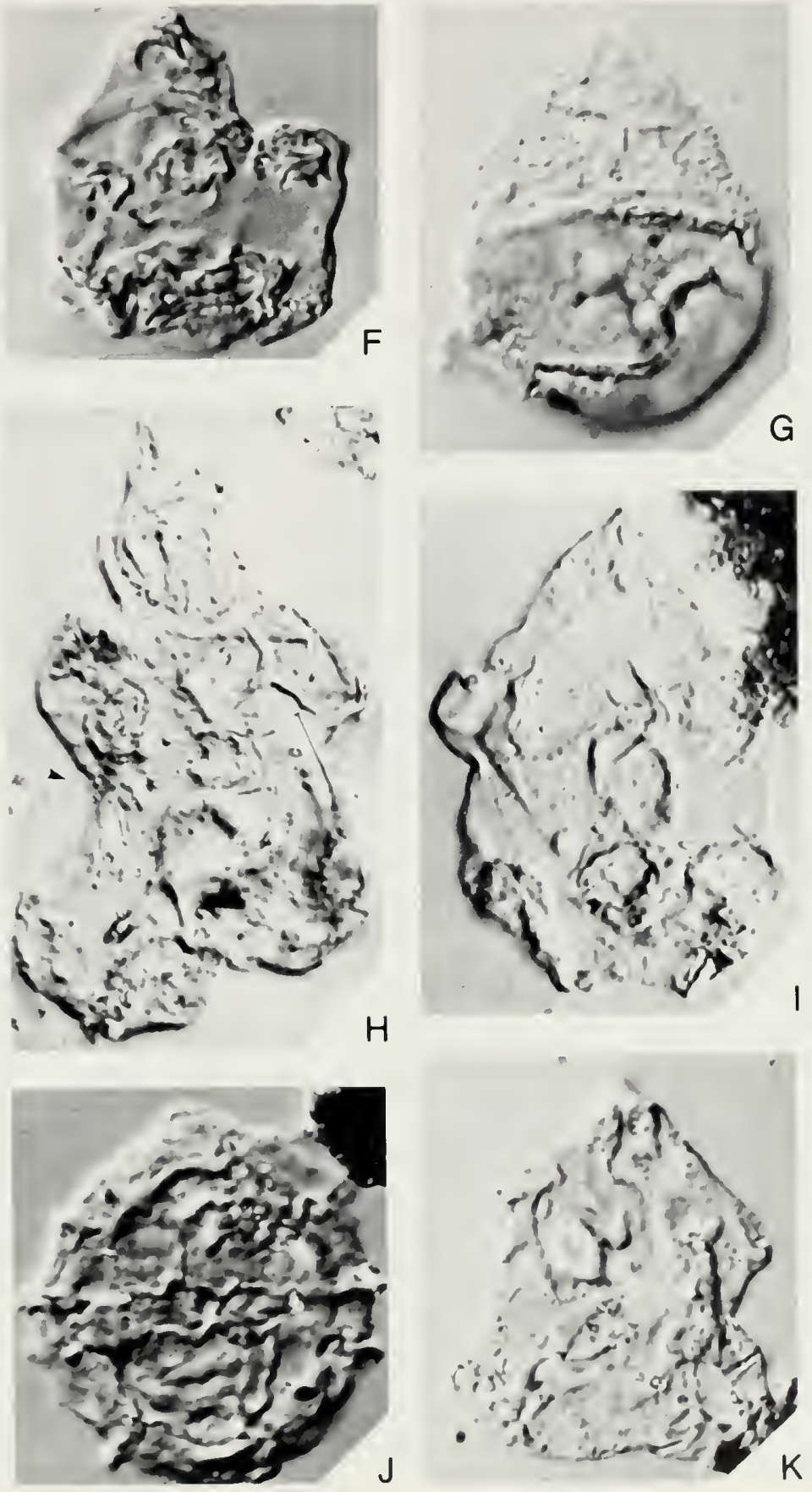
Fig. 25 Scanning electron photomicrographs.

A-D Susadinium scrofoides sp. nov., ventral view, ED 1030-4, Savik Fm., Ellef Ringnes Island, Arctic Canada. A $\times$ 3045. B $\times$ 3045, ROM 36983. C $\times 1220 . \mathrm{D} \times 3045$, ROM 36986.

E Dapcodinium inornatum (Morgenroth) comb. nov. dorsal view, $\times$ 1220. Savik Fm., Ellef Ringnes Island, ROM 36987.

F Mendicodinium sp., ventral view with epitractal archeopyle. ED 1030-1, × 1220, ROM 36988, Savik Fm., Ellef Ringnes Island, Arctic Canada.

G Dapcodinium semitabulutum (Morgenroth) comb. nov., ventral view, apical series attached ventrally. $\times$ 1220, Savik Fm., Ellef Ringnes Island, Arctic Canada, ED 1030-1, ROM 36984. 

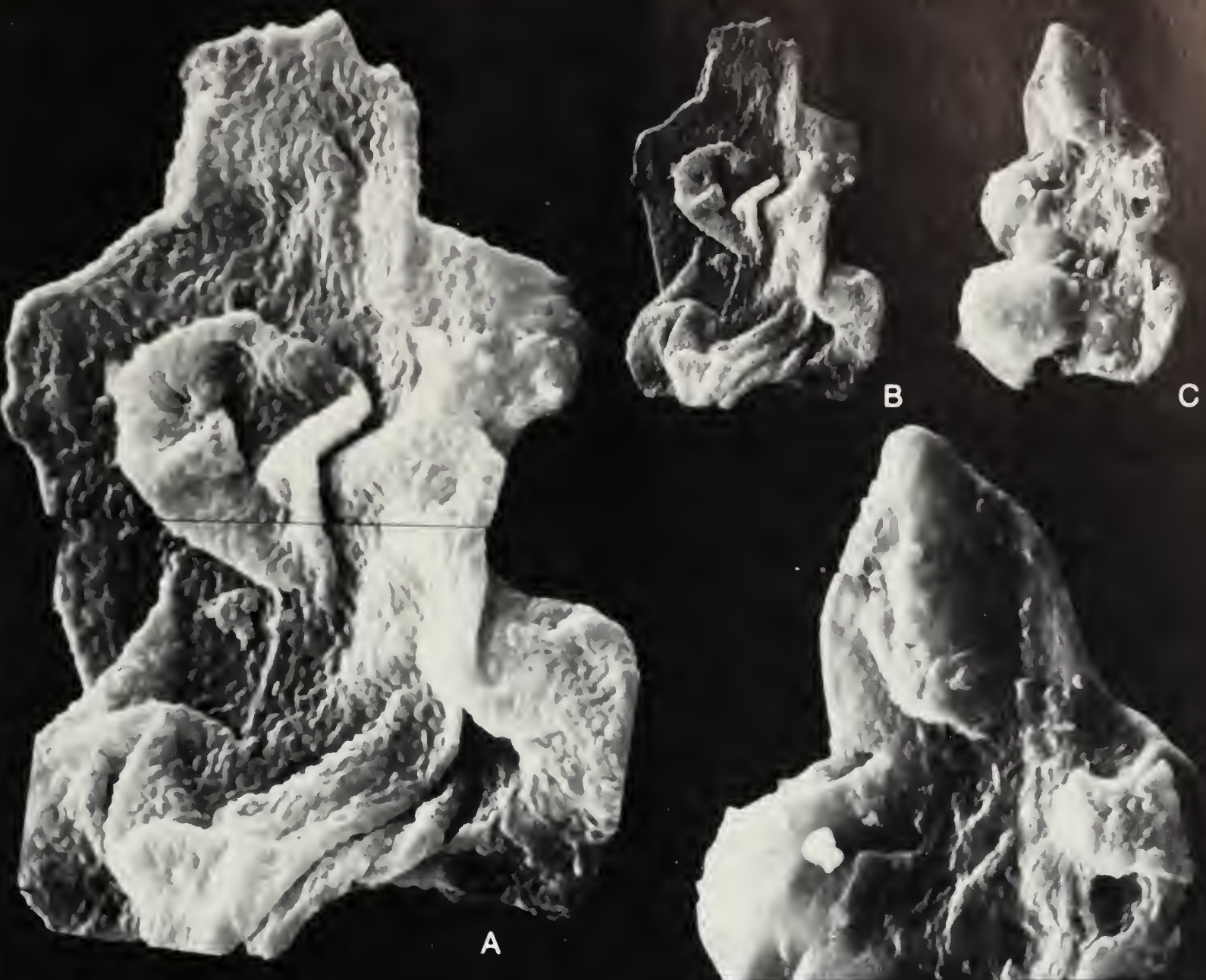

D
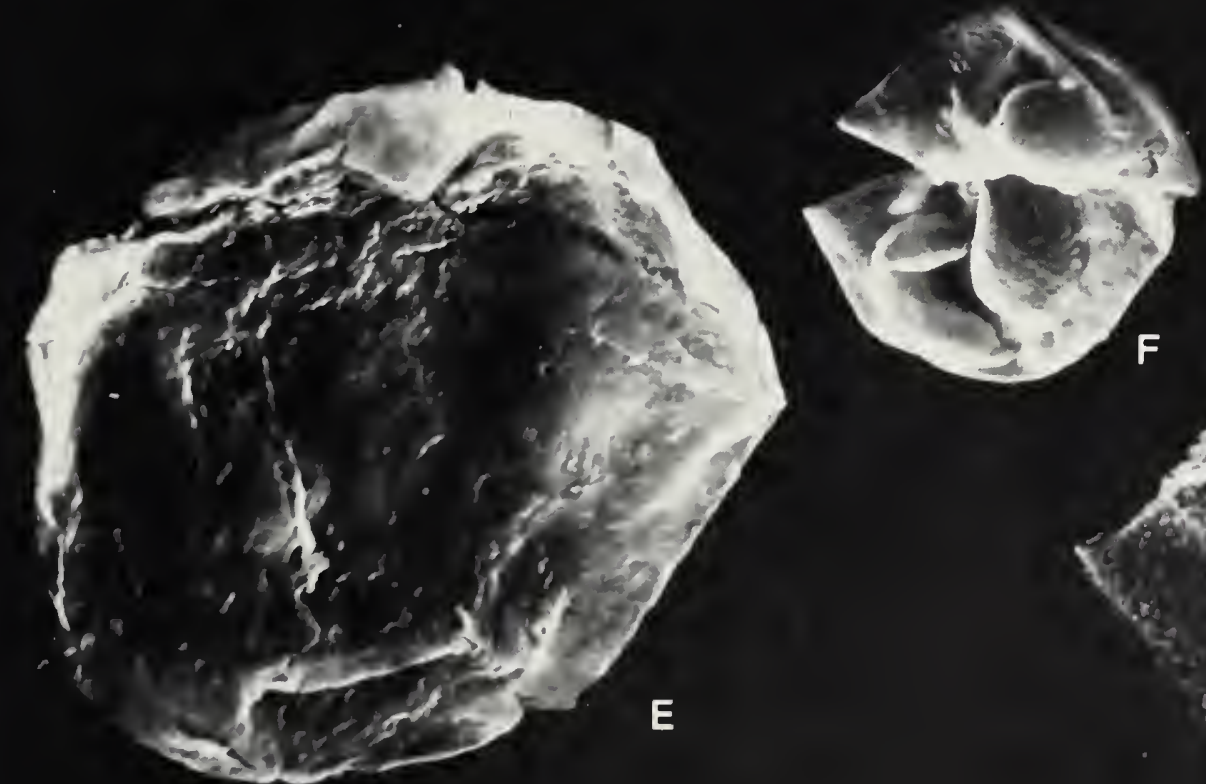
Fig. 26 A-D Dodekoria syzygia sp. nov., holotype.

A Bright field optics, dorsal view.

D Bright field optics, ventral view. Notice plates around sulcus.

B Dorsal view.

C Ventral view.

Reindeer Peninsula, ED 1030-4a, ROM 36628, 55.9/98.6, Jaeger Mb., Savik Fm., Arctic Canada.

E Comparodinium aquilonium sp. nov., holotype. Initial archeopyle formation, two opercular pieces in place, focus on the intercalary opercular piece partly inside the autoblast. Elf Wilkins E-60, WI 1950-a, ROM 36470, 35.6/95.2, Savik Fm., Arctic Canada.

F-G Dodekovia syzygia sp. nov., showing opercular plates in situ. Reindeer Peninsula, ED 1030-4a, ROM 36628, 56.1/99.0, Jaeger Mb., Savik Fm., Arctic Canada.

H Phallocysta eumekes sp. nov., showing the angular outline of the archeopyle in lateral view. Reindeer Peninsula, ED 1031-4a, ROM 36631, 54.3/95.4, Jaeger Mb., Savik Fm., Arctic Canada.

I Comparodinium aquilonium sp. nov., paratype. Exhibiting the angular archeopyle suture. Elf Wilkins E-60, W1 2070a, ROM 36474, 51.0/93.8, Savik Fm., Arctic Canada.

J Phallocysta eumekes sp. nov., paratype. Due to twisting of epitract the archeopyle appears as an irregular slit. Elf Wilkins E-60, WI 1320A, ROM 36449, 45.1/98.2, Savik Fm., Arctic Canada.

K Phallorysta eumekes sp. nov. holotype showing the 31 archeopyle. Reindeer Peninsula, ED 1031-4A, ROM 36631, 35.2/100.1, Jaeger Mb., Savik Fm., Arctic Canada. 

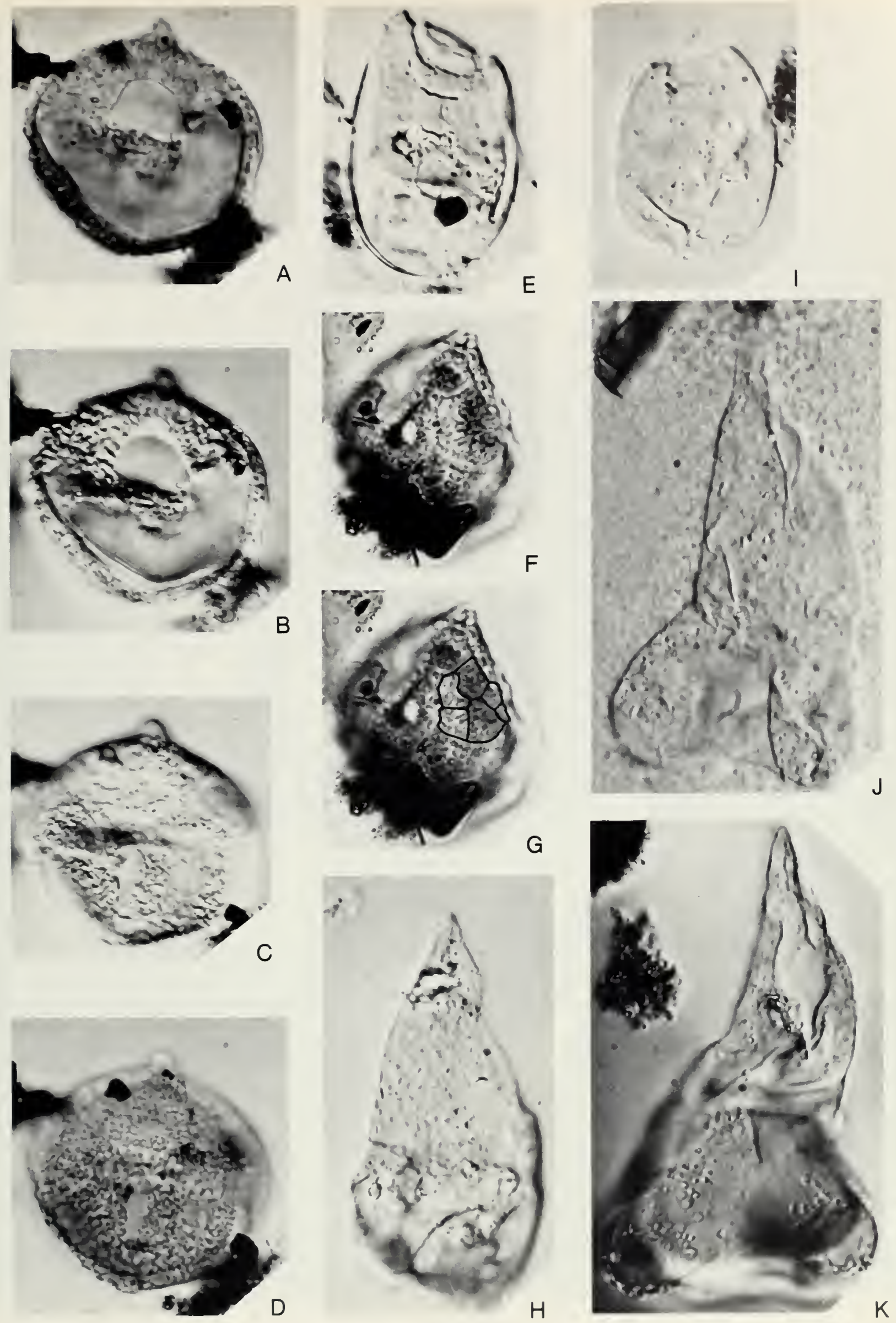
Fig. 27 Scanning electron photomicrographs. All specimens are from sample ED 1031-4, Jaeger Mb., Savik Fm., Reindeer Peninsula, Arctic Canada.

A-D, G Phallocysta eumekes sp. nov., ROM 36986.

A-C Left lateral view, $\times 1220$.

D Ventral view, $\times 1220$.

G Antapical view, $\times 1220$.

E, F, I Phallocysta eumekes sp. nov., ROM 36976.

E Dorsal view, $\times 975$.

F Left lateral view, $\times 975$.

I Close-up of archeopyle, $\times 4440$.

H Phallocysta eumekes sp. nov., close-up of archeopyle, showing surface texture and double layered wall. $\times 4800$, Rом 36976 . 

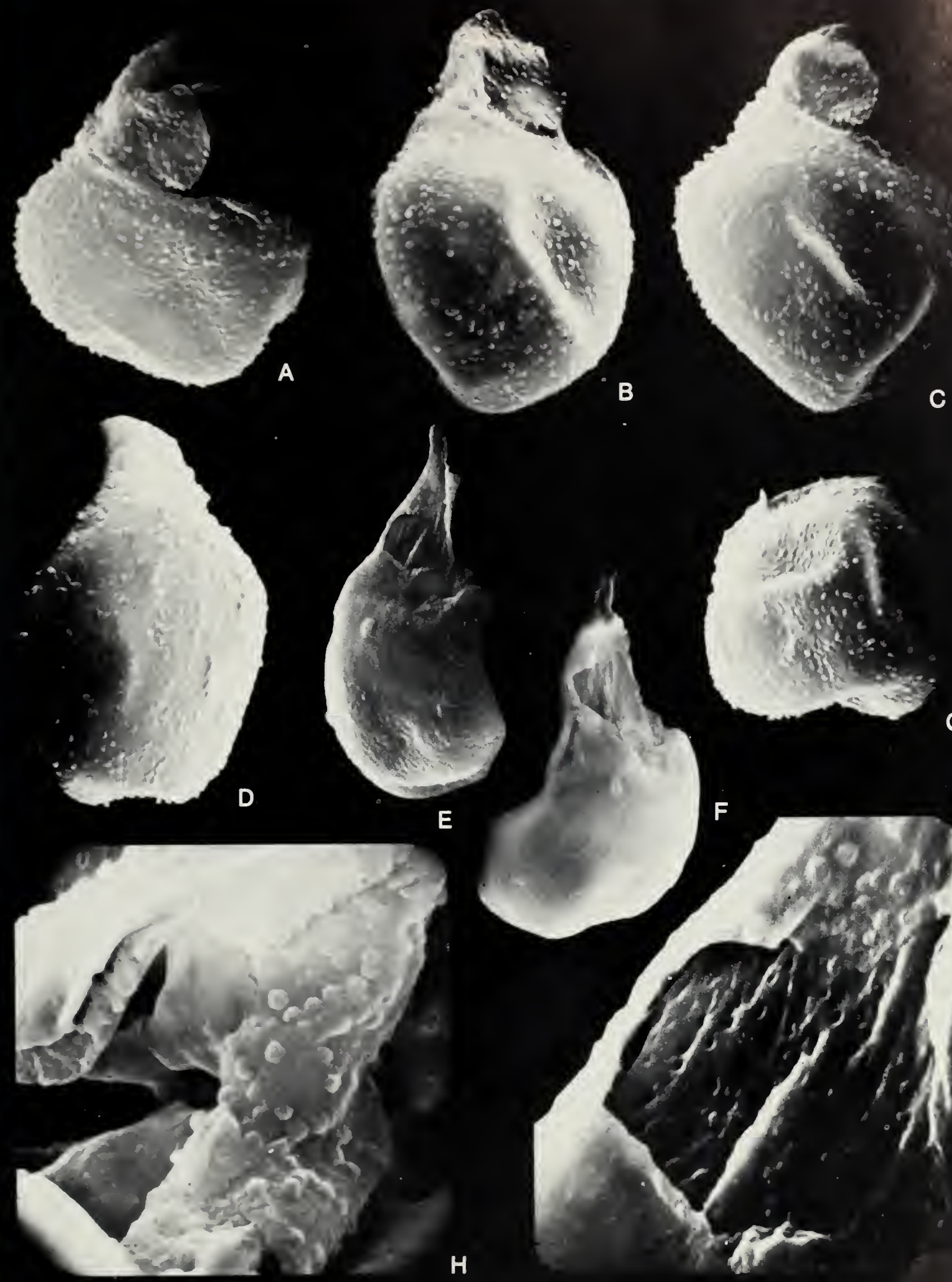

H

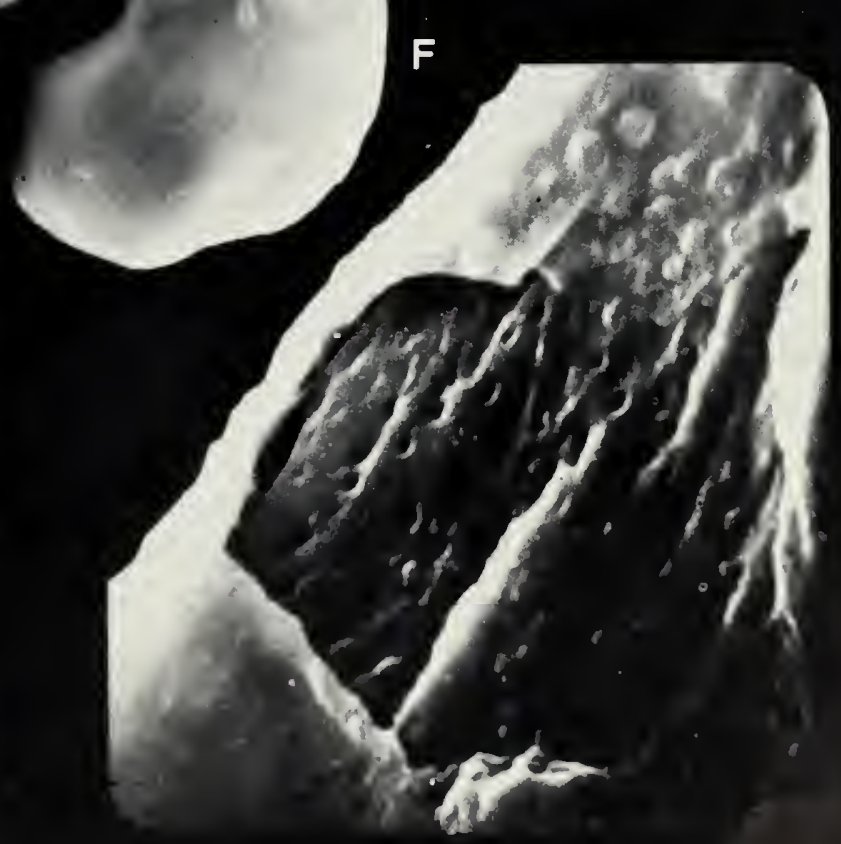


Fig. 28 Scanning electron photomicrographs. All specimens are from sample 1030-4, Savik Fm., Ellef Ringnes Island, Arctic Canada.

A-H Comparodinium aquilonium sp. nov.

A, D Right lateral view exhibiting initial archeopyle development. A $\times 1440$. D $\times 3600$, ROM 36986 .

B Left lateral view, $\times 1440$, ROM 36983.

C Ventral view of whole specimen, $\times 1440$, ROM 36989.

E, F Ventral view, showing initial archeopyle splitting. $\mathrm{E} \times 1440, \mathrm{~F} \times 3600$, ROM 36989.

G, H Right lateral view showing two opercular pieces slightly displaced, ROM 36989 . G $\times 3600$. H $\times 1440$, ROM 36989. 

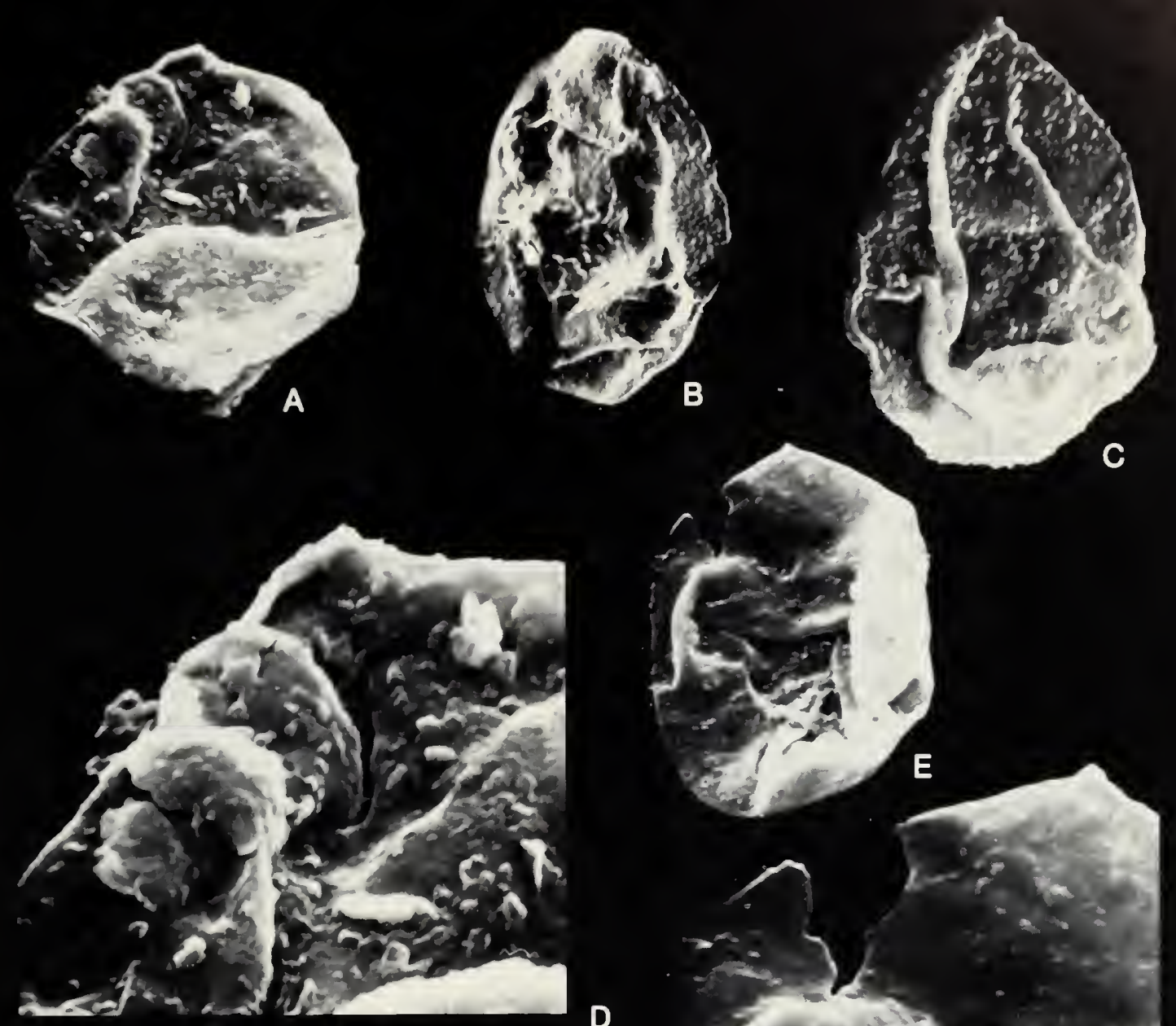

D
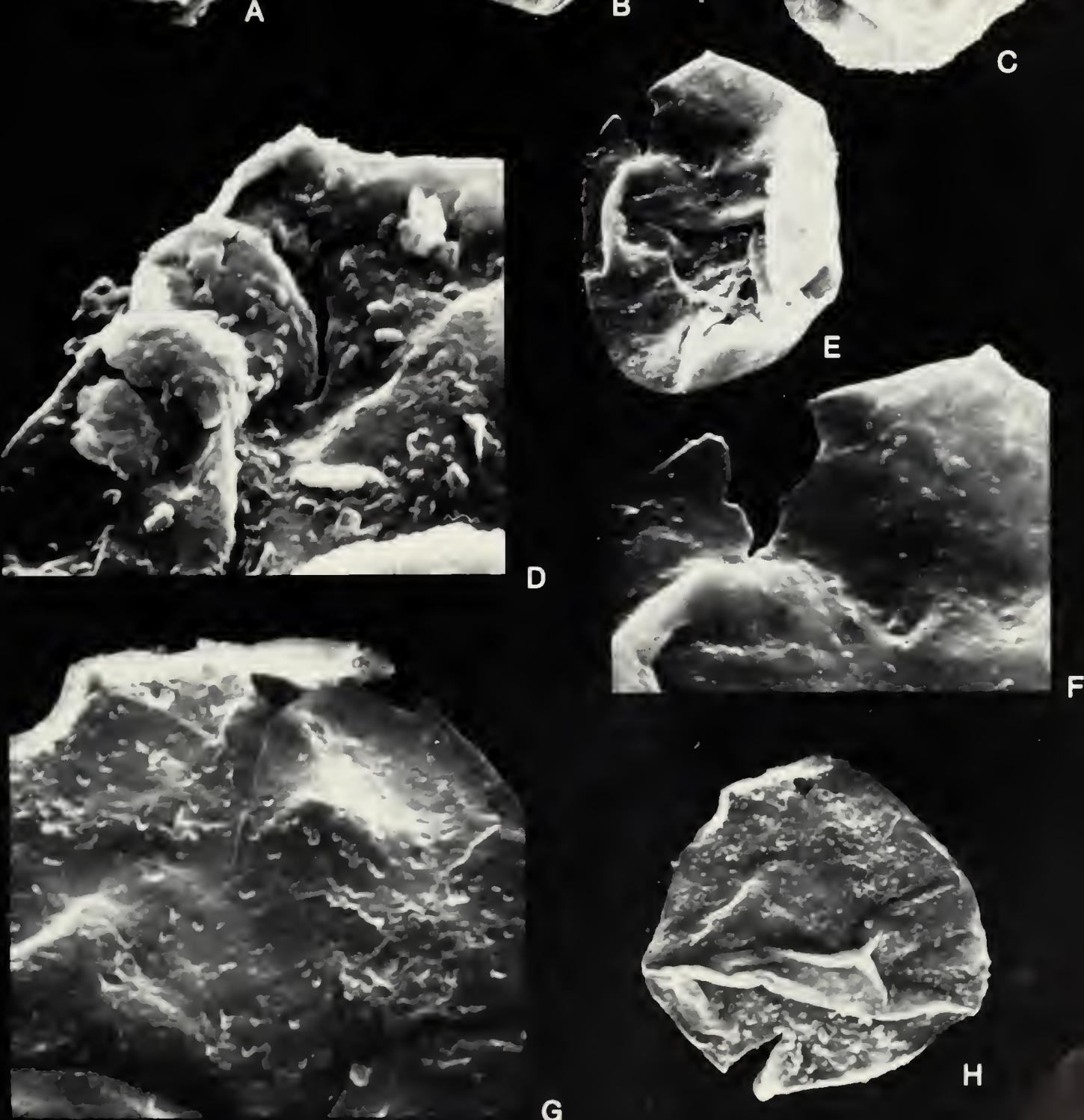

G

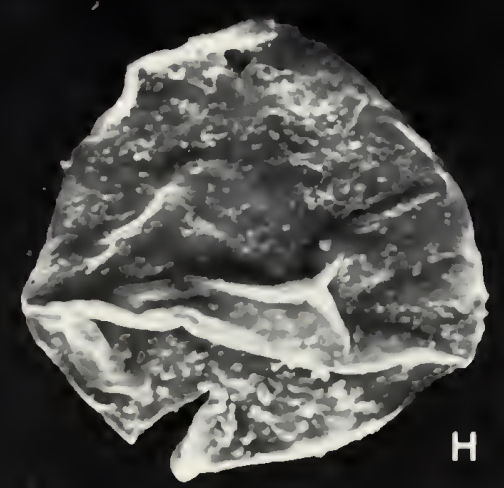


Fig. 29 A Glomodinium sp. showing (3I) archeopyle and hypotractal bulge as an indication of a lateral horn. Central Amund Ringnes Dome, ED 1009-7Aa, ROM 36641, 47.5/101.6, Savik Fm., Arctic Canada.

B Glomodinium tripartitum (Johnson and Hills) Dodekova 1975. Initial archeopyle formation, three intercalary plates detaching separately. Central Amund Ringnes Dome, ED 1009-1a, ROM 36635, 43.0/105.7, Savik Fm., Arctic Canada.

C Glomodinium tripartitum (Johnson and Hills) Dodekova 1975, showing three intercalary plates in place. Central Amund Ringnes Dome, ED 1009-1a, ROM 36635, 40.3/101.4, Savik Fm., Arctic Canada.

D-F Paragonyaulacysta retiphragmata sp. nov., holotype, showing pronounced sutural ridges and 3I archeopyle. Elf Jameson Bay C-31, JB 1260a, ROM 36529, 55.1/105.9, Savik Fm., Arctic Canada. 

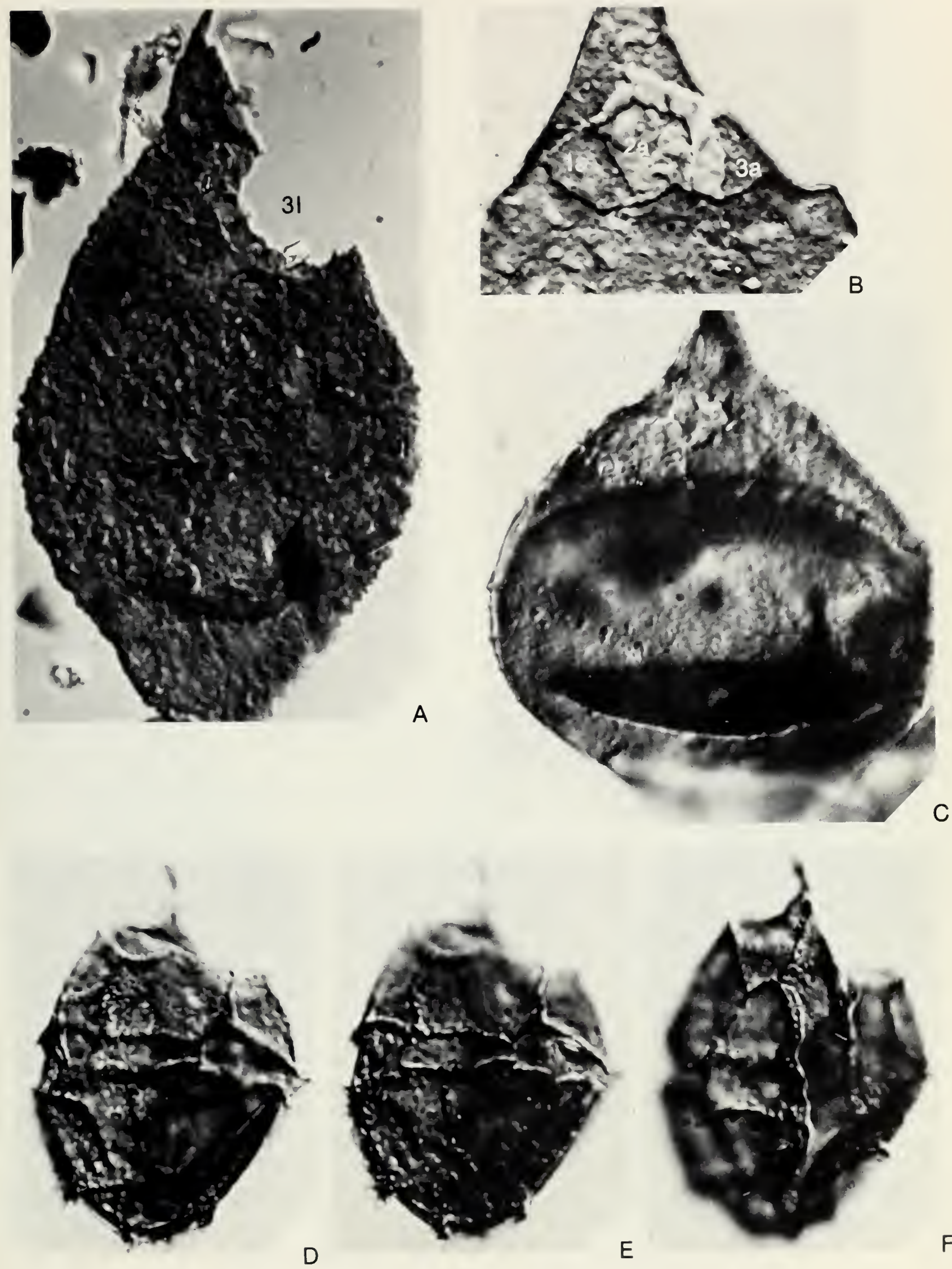
Fig. 30 A-E Imbatodinium kondratjevi Vozzhennikova emend. All specimens are from the Deer Bay Fm., North Amund Ringnes Dome, Amund Ringnes Island, Arctic Canada.
A Dorsal view, showing surface granulation and faint plate sutures. ED 1028-21A, ROM 36776, 43.8/99.6.
$B$, D Dorsal view. Some sutures are discernible. Note the low position of the cingulum $(C)$ and the pronounced omphalos (OM). ED 1028-21A, ROM 36776, 43.5/106.8
D Bright field optics, $\times 875$.
C Coarse variety, ED 1028-19A, ROM 36775, 33.8/110.2.
E Ventral view, operculum removed, ED 1028-21c, ROM 36805, 46.7/95.1. 

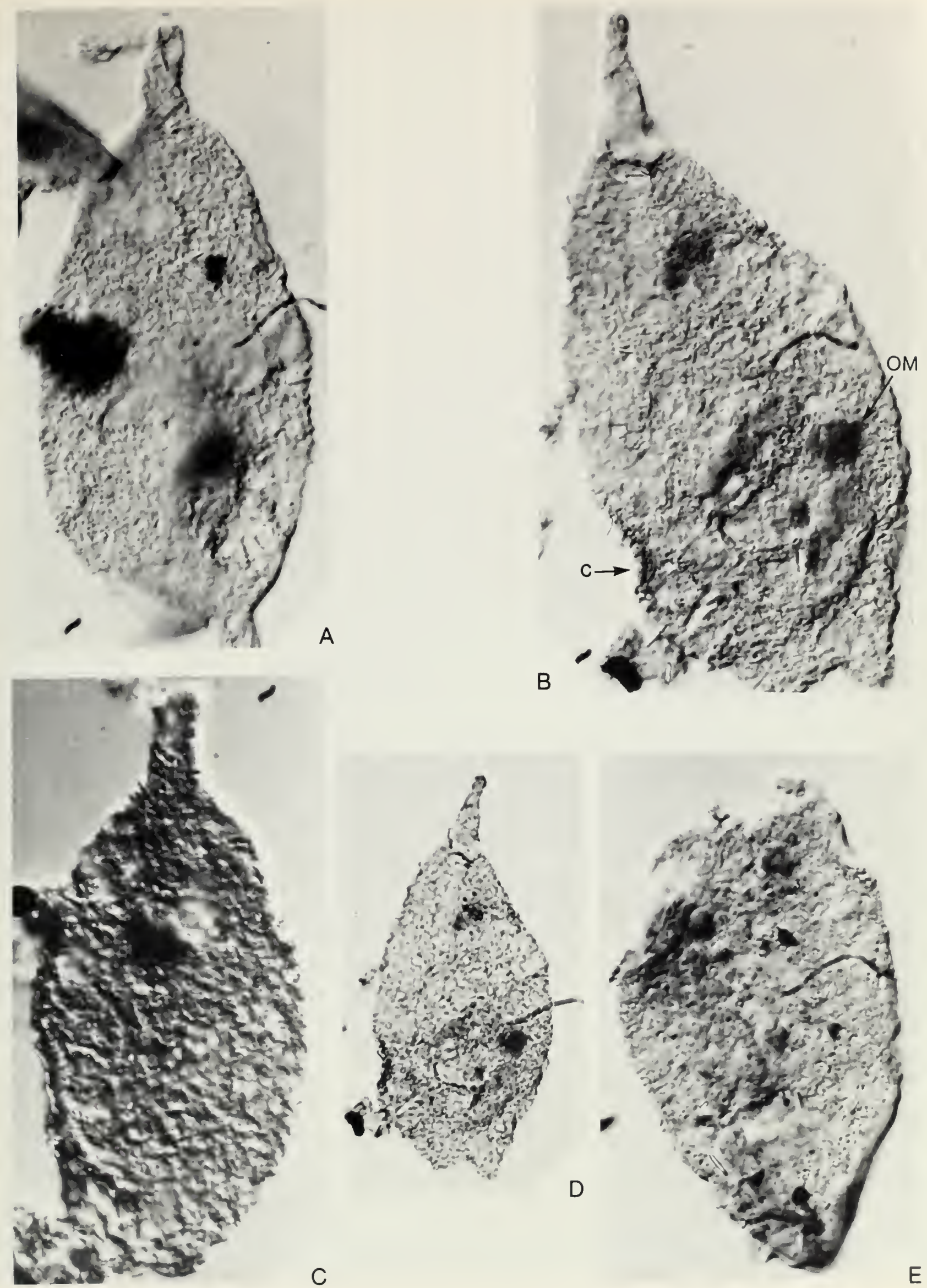
Fig. 31 Scanning electron photomicrographs. All specimens are from sample ED 1028-21, Deer Bay Fm., North Amund Ringnes Dome, Amund Ringnes Island, Arctic Canada.

A-F Imbatodinium kondratjevi Vozzhennikova emend.

A, B Ventral view, showing sulcal area (S), cingulum (C) and faint archeopyle sutures (AS and arrows), ROM 36981. A $\times 975$. B $\times 1940$.

C, F Oblique ventral view, showing archeopyle initiation. $\mathrm{C} \times 1940 . \mathrm{F} \times 900$, ROM 36981 .

D, E Ventral view, showing archeopyle suture. D $\times 1860 . \mathrm{E} \times 930$, ROM 36981 . 


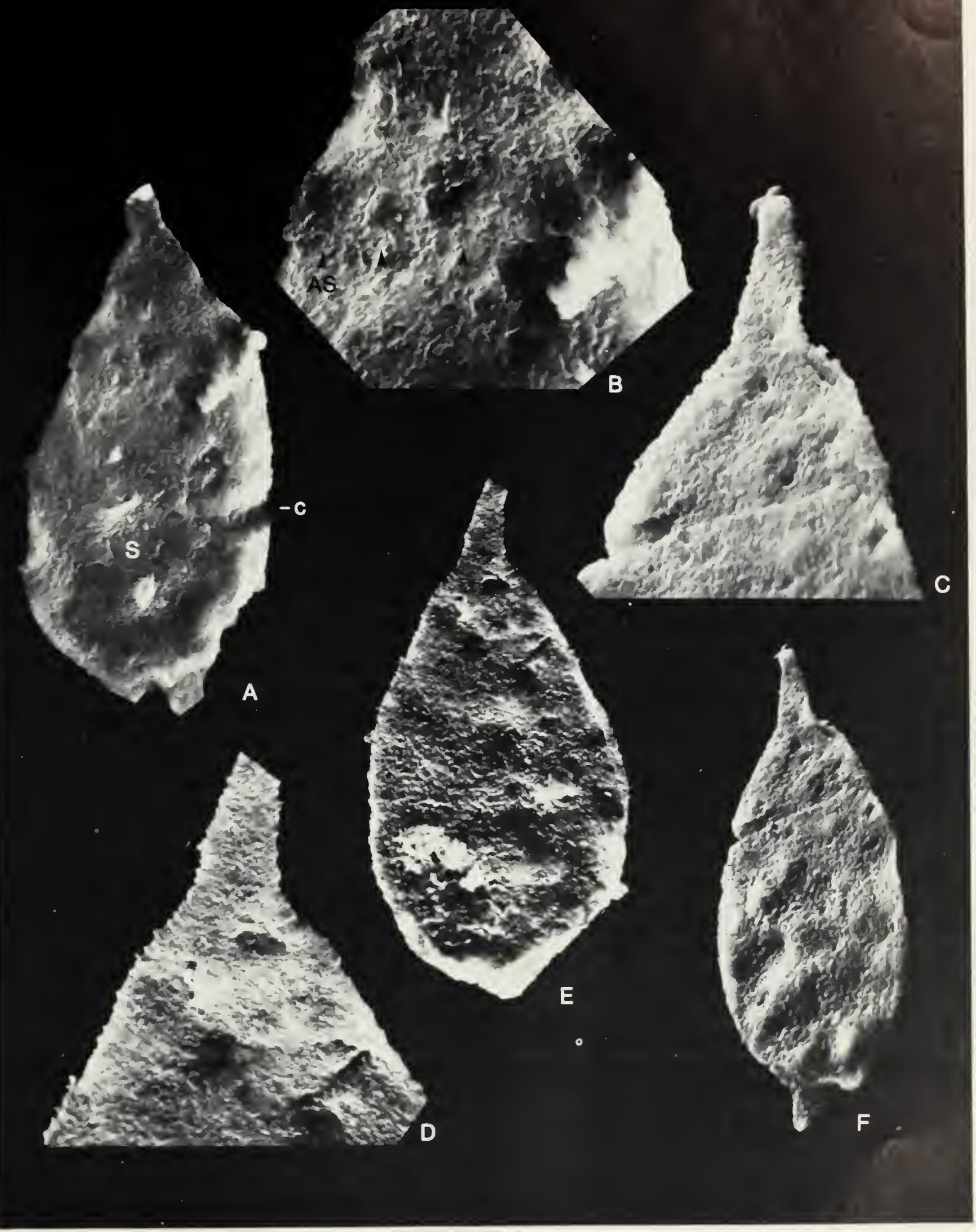


Fig. 32 Scanning electron photomicrographs.

A, D Imbatodinium micropodum (Eisenack and Cookson 1960) comb. nov., ROM 36988.

D Ventral view, showing incipient archeopyle formation; also note low position of cingulum (C), $\times 1220$.

A Enlarged postion of surface showing fine granular wall structure. (Compare the illustration in Davey 1974, pl. 7, fig. 8.) $\times 3045$, KBT 10/39.5, Aptian, Germany.

B, F Imbatodinium sp., ROM 36990 .

F Ventral view, $\times 1220$.

B Enlarged portion of surface, showing finely reticulate surface pattern, $\times 6080$. KBT 9/48.5, Aptian, Germany.

C, G Imbatodinium jaegeri (Alberti) comb. nov., ROM 36981.

G Ventral view, note archeopyle suture, $\times 1765$.

C Enlarged portion of surface, showing chagrenate surface pattern, 4020. KBT 10/39.5, Aptian, Germany.

E Imbatodinium longicornutum (Alberti) comb. nov. Left lateral view, operculum removed, surface smooth, $\times$ 970. Gehrden 31, Upper Barremian, Germany, ROM 36979.

H Imbatodinium sp. Apex with archeopyle initiation, $\times$ 3045. KBT 10/39.5, Aptian, Germany. 

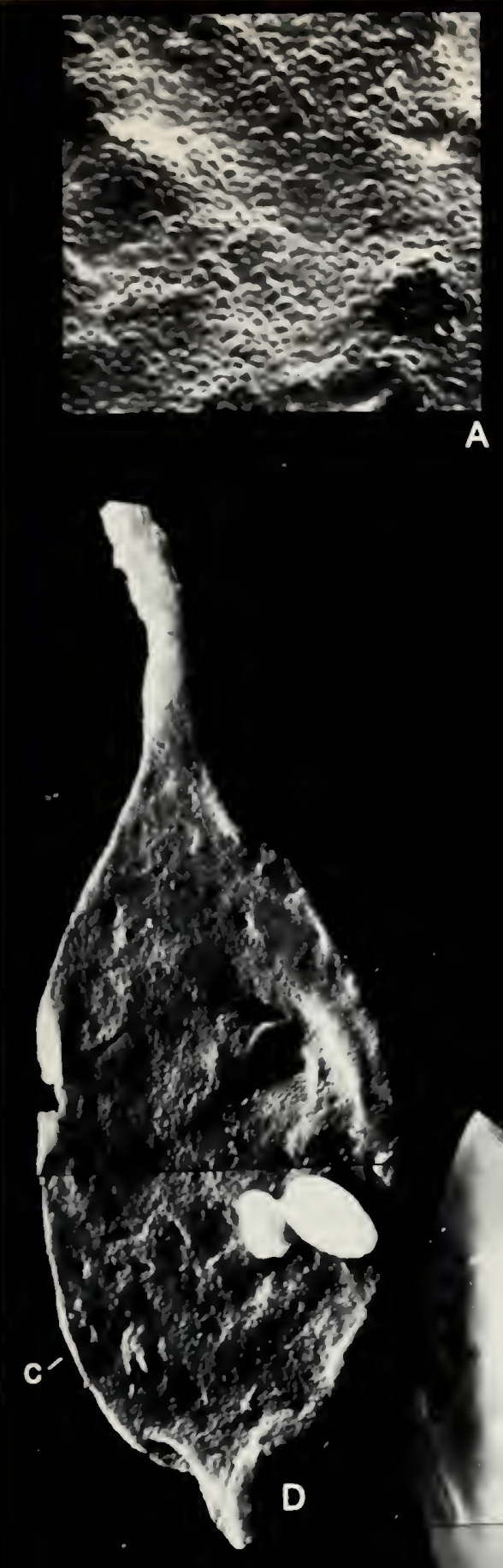

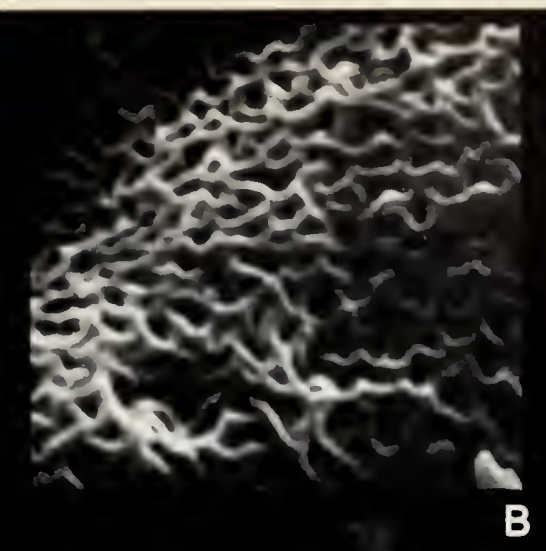

B

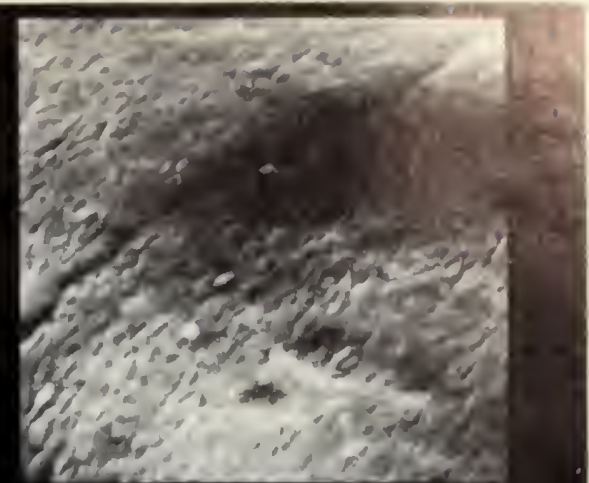

C

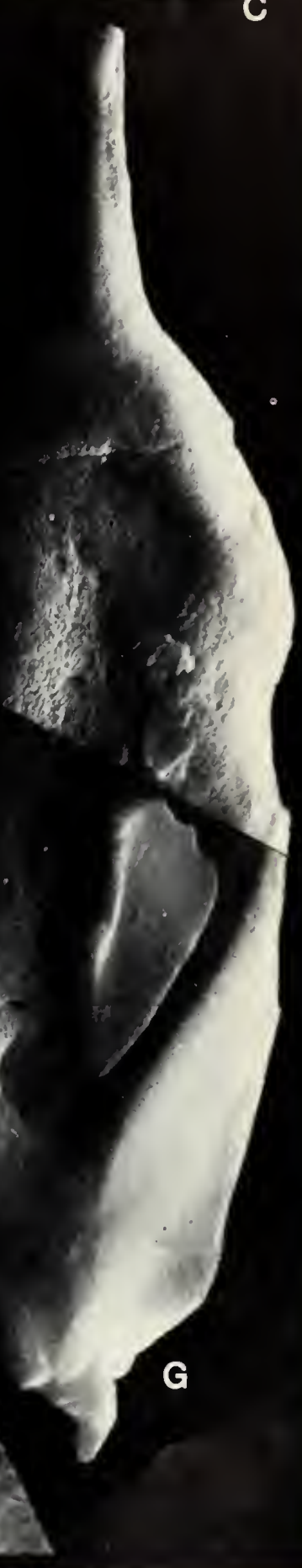


Fig. 33 A-D Imbutodinium pelliferum (Alberti) comb. nov., exhibiting the archeopyle suture and faint tabulation traces. Note the low position of cingulum and pronounced omphalos (OM, on D). KTH1/30/5a, ROM 36967, 47.8/96.4, Hauterivian, Germany.

E Cyclonephelium distinctum Deflandre and Cookson 1955. Ventral view, showing ventrally attached operculum, × 770. KBT 10/39.5, Aptian, Germany, ROM 36992.

F, G Gochteodinia villosa (Vozzhennikova) Norris 1978, ROM 36988.

F Oblique dorsal view, apical horn partly broken off. Note the cingular area free of processes $(C) . \times 650$.

G Enlarged portion, showing 2I archeopyle with opercular plates in place and processes presumably in penitabular position. $\times$ 1220, ED 1004-3, Jaeger River, Cornwall Island, Arctic Canada.

E-G Scanning electron photomicrographs. 

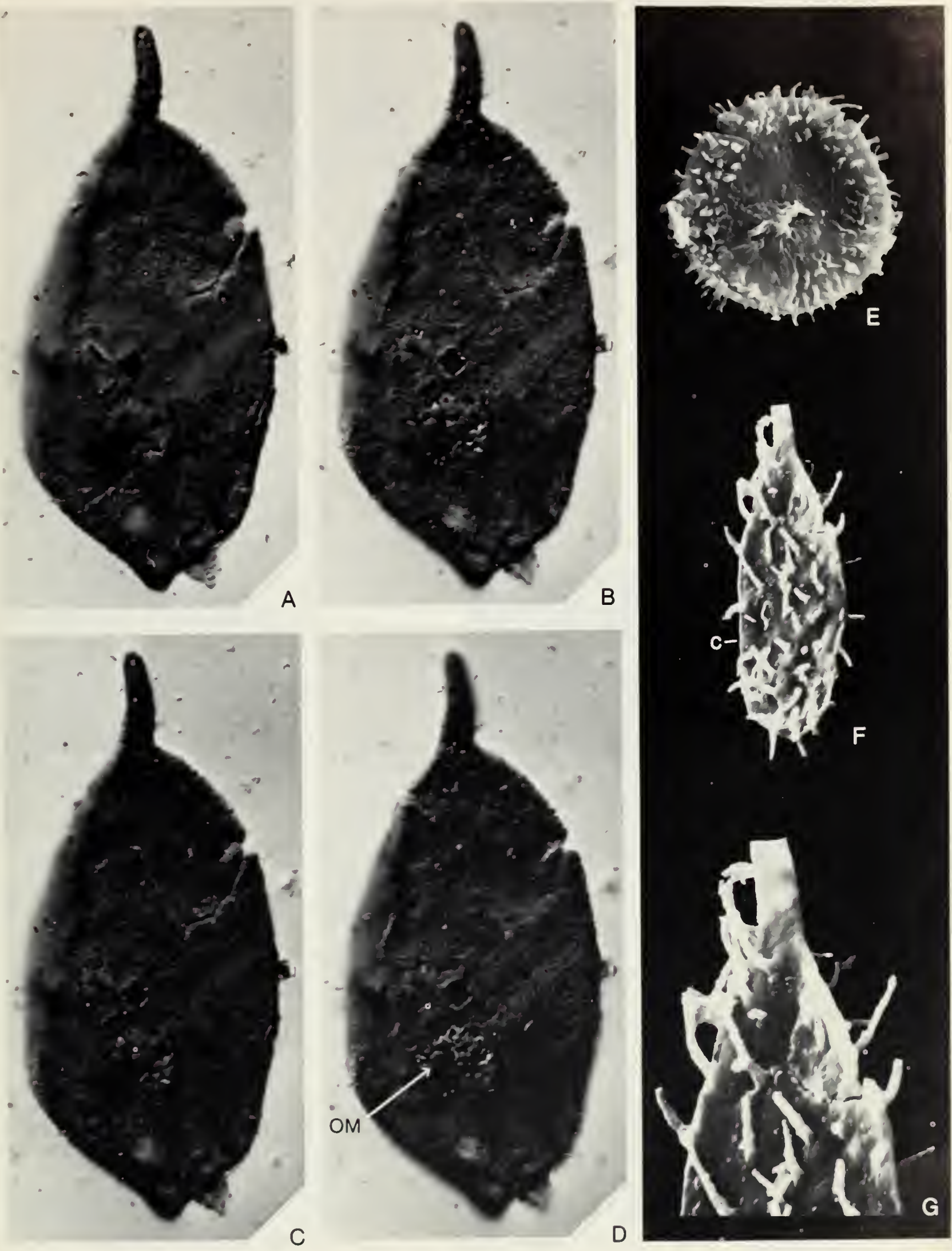
Fig. 34 A, B Endoceratium dettmannae (Cookson and Hughes) Stover and Evitt 1978, showing asymmetrical archeopyle suture (AS) and breakage of the operculum along the intercalary suture (IS) between the apical and the intercalary plate series. Also apparent are two pronounced postcingular horns, a pronounced left antapical horn, and a bulge indicating a right antapical horn. Note dark omphalos (OM). A scale B, Os 924/3s, ROM 36969, 55.3/96.5, Latest Albian, Germany.

C Imbatodinium kondratjevi Vozzhennikova emend., operculum, ventral view on inside of dorsal intercalary plates. Compare with operculum of 1 . jaegeri (Fig. 35D). ED 1028-21C, ROM 36805, 43.0/107.7, Deer Bay Fm., North Amund Ringnes 1sland, Arctic Canada.

D Muderongia simplex ventral view, showing $1^{\prime}$ and $4^{\prime}$. The right postcingular horn is bent upwards. ED 1002-4a, ROM 36715, 40.0/105.9. Deer Bay Fm., Cape Ludwig. Amund Ringnes Island, Arctic Canada.

E Imbatodinium kondratjevi Vozzhennikova emend., apical part, showing archeopyle suture (AS) and intercalary plates (1a, 2a). ED 1028-21 A, ROM 36776, 38.5/95.8, Deer Bay Fm., North Amund Ringnes Island, Arctic Canada.

F Komewuia glabra Cookson and Eisenack 1960, oblique dorsal view, showing 21 archeopyle, slightly granular surface, and kalyptra. No endoblast is developed; circular folds are due to compression. ED 1047-7A, ROM 36741, 44.2/107.4, Savik Fm., North West Cornwall 1sland, Arctic Canada. Scale B.

G Gochteodinia villosa (Vozzhennikova) Norris 1978. Oblique dorsal view, exhibiting 21 archeopyle with opercula slightly displaced. ED 1041-1 A, ROM 36801, 47.7/103.2, Deer Bay Fm., West Cornwall Island, Arctic Canada. Scale B. 

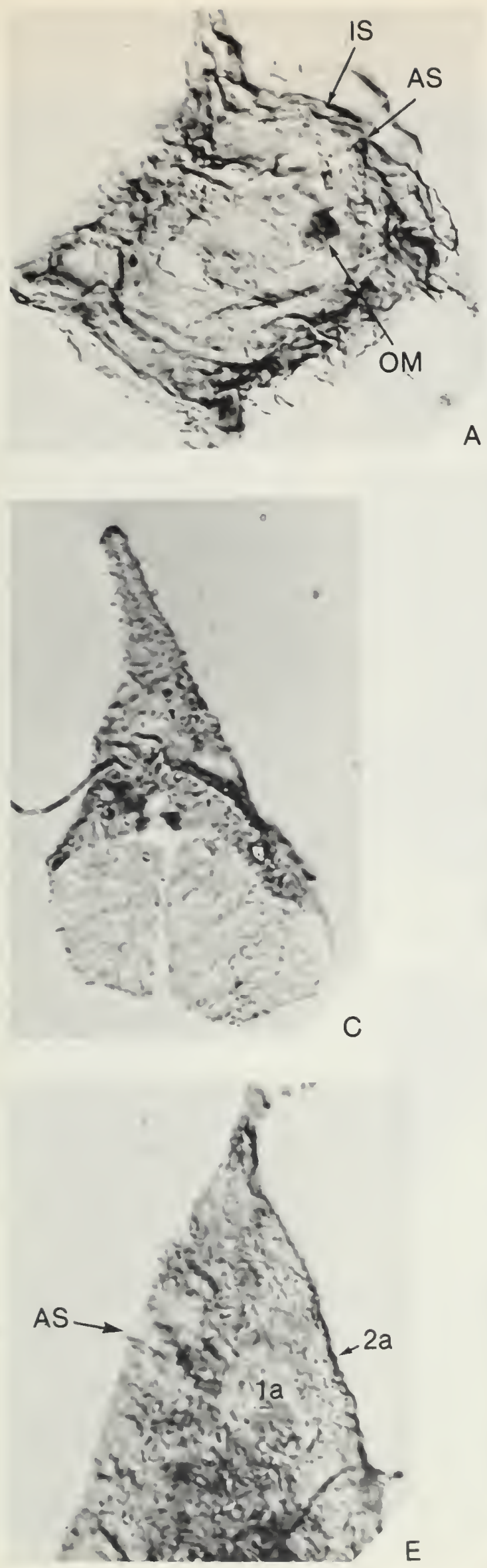
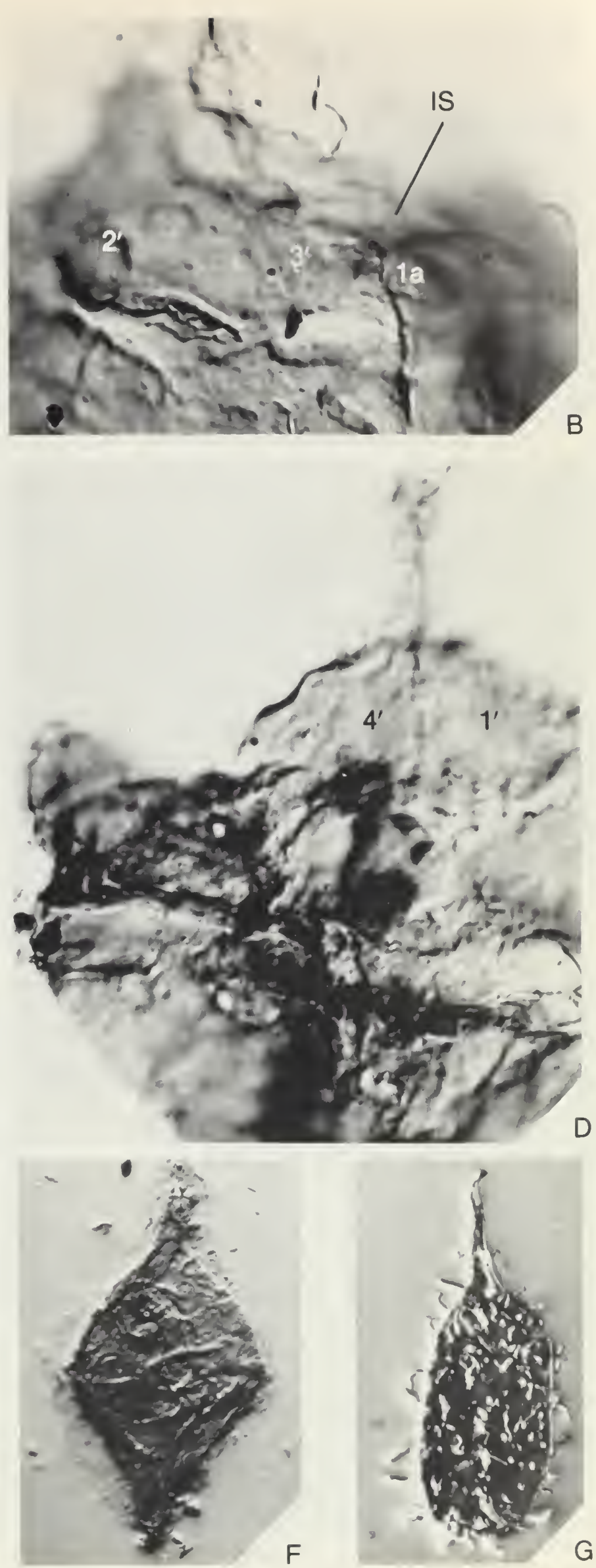
Fig. 35 A, D Imbatodinium jaegeri (Alberti) comb. nov., showing asymmetrical archeopyle suture (AS) and faint elongate precingular plates. ED 1004-3b, ROM 36678, 38.8/93.6, Deer Bay Fm., Jaeger River, Cornwall Island, Arctic Canada.

B, C Phoberocysta neocomica (Gocht) Millioud 1969, showing asymmetrical archeopyle suture, adjacent plate boundaries and postcingular horns. KTH I/20/4a, ROM 36970, 51.4/93.8. Hauterivian, Germany.

E Imbatodinium jaegeri (Alberti) comb. nov., Operculum. ED 1004-3b, ROM 36678, 35.3/93.38, Deer Bay Fm., Jaeger River, Cornwall Island, Arctic Canada.

F Pseudoceratium pelliferum Gocht 1957. Apical area showing the asymmetrical archeopyle suture and a possible intercalary suture (?IS). Mo 551/5s, ROM 36971, 49.3/99.9, Middle Albian (reworked), Germany. 

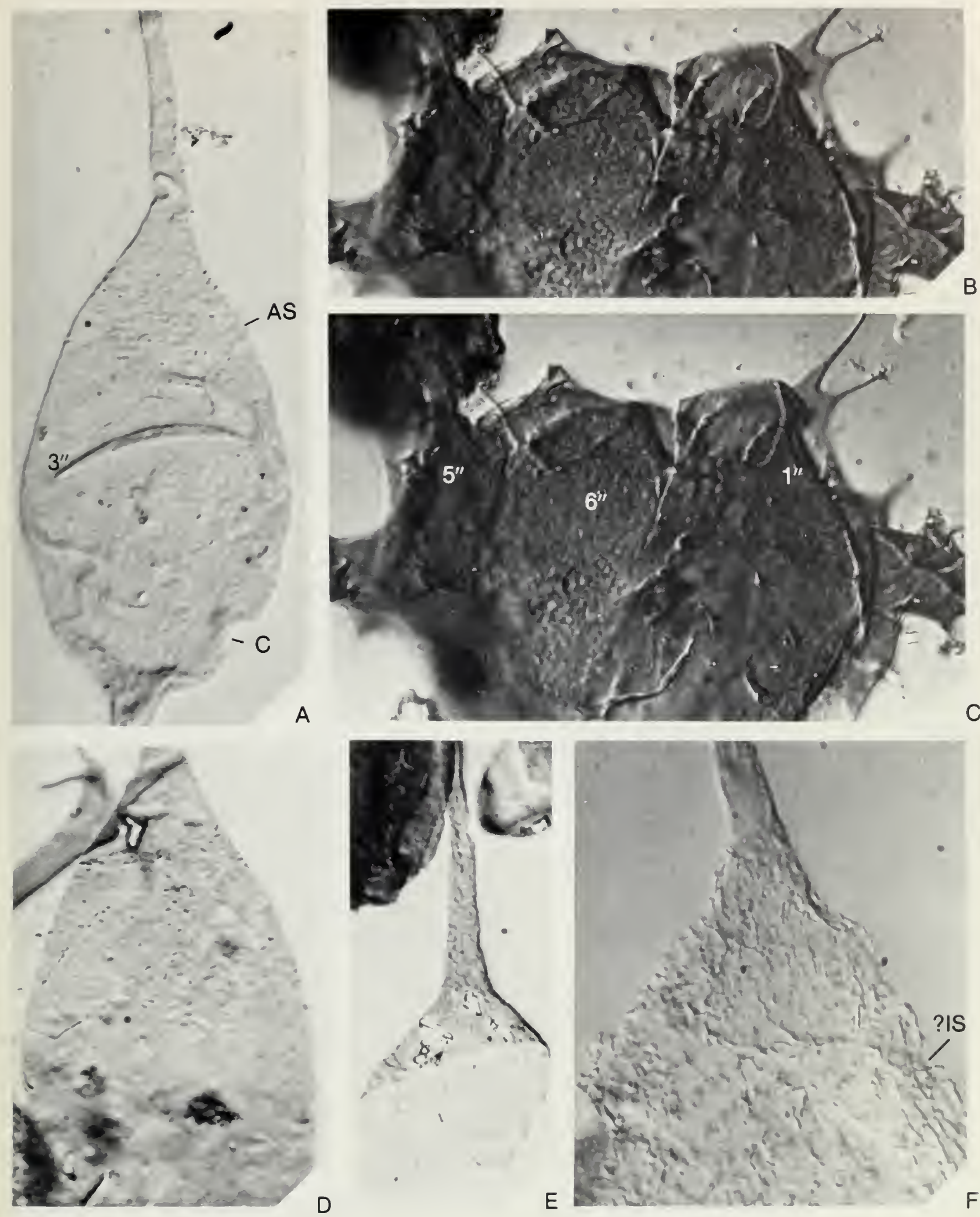
Fig. 36 Scanning electron photomicrographs. All Muderongia specimens are from sample ED 1002-4, Deer Bay Fm., Cape Ludwig, Amund Ringnes Island, Arctic Canada.

A, B Heterosphaeridium heteracanthum (Deflandre and Cookson) Eisenack and Kjellström 1971. Complete specimen with partly detached operculum. Note the typical asymmetrical pseudoceratiacean shape of the latter, which dips down dorsally to the right. Also compare the nature of processes with that of Aptea polymorpha (Fig. 37A) and Pseudoceratium pelliferum (Fig. 37D). A $\times 1220$. B $\times 3045$, KBT 10/39.5, Aptian, Germany, ROM 36991 .

C, F Muderongia simplex Alberti 1961. Dorsal view, showing partly detached operculum and position of anterior intercalary plates $(1-2 \mathrm{a}) . \mathrm{C} \times 730 . \mathrm{F} \times 1220$, ROM 36985.

D Muderongia simplex Alberti 1961. Isolated operculum, showing anterior intercalary plates. $\times 1525$, ROM 36978 .

E Muderongia simplex Alberti 1961. Ventral view, showing incipient archeopyle formation, cingulum, and sulcal area. $\times 730$, ROM 36979.

G Muderongia simplex Alberti 1961. Apex, showing incipient archeopyle formation and double nature of the wall. $\times$ 1525, ROM 36980 . 


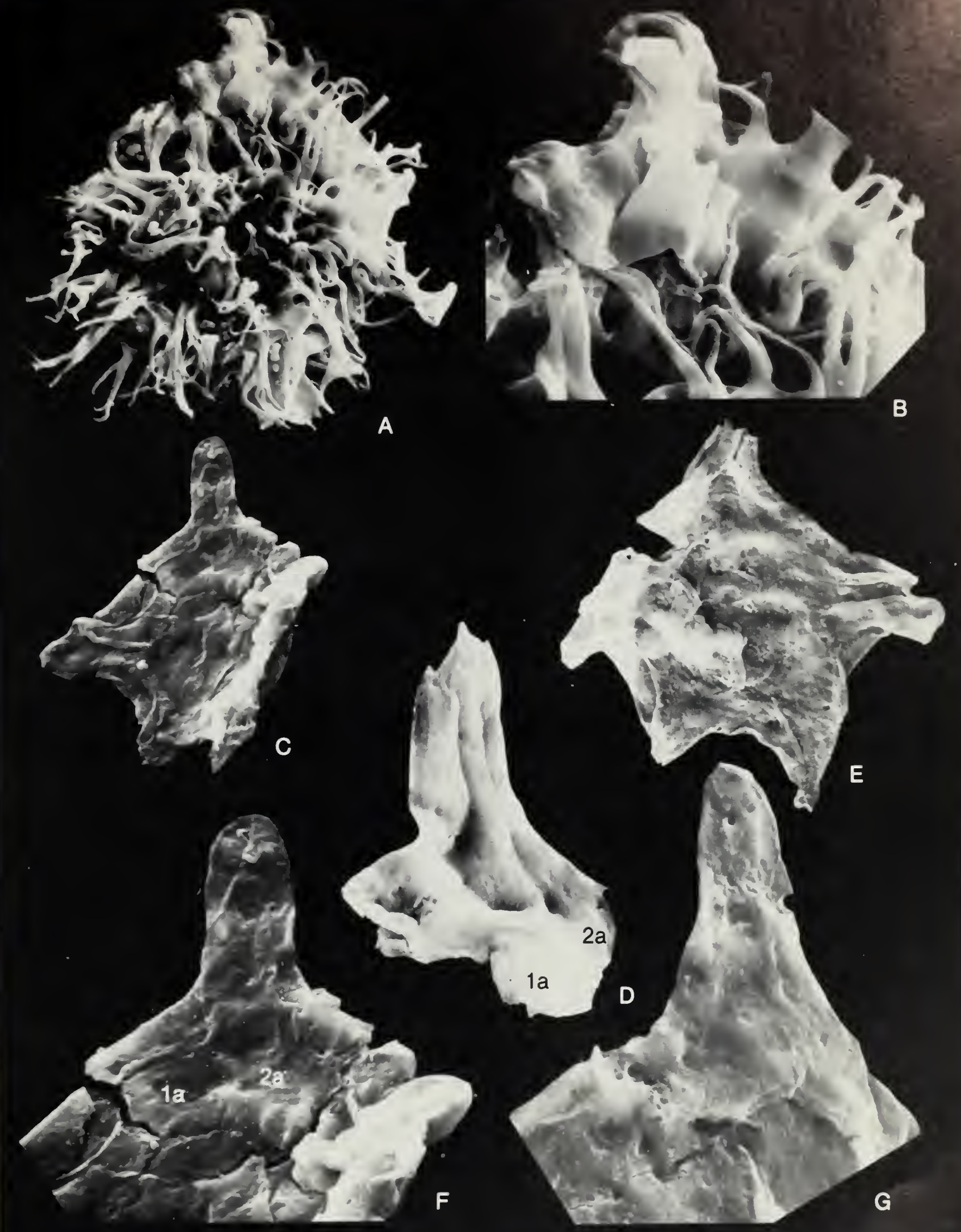


Fig. 37 Scanning electron photomicrographs

A Aptea polymorpha Eisenack emend. Detail of processes. $\times 3065$, KBT 10/39.5, Aptian, Germany, ROM 36993.

B-E Pseudoceratium pelliferum Gocht 1957. Gehrden 31, Upper Barremian, Germany, ROM 36979.

C Complete specimen, showing penitabular ornament. $\times 730$.

B Detail of cingular area. $\times 1460$.

D Detail of surface and processes. Compare with Fig. 1. Note archeopyle suture (AS). $\times 3640$.

E Detail of apical area and archeopyle suture (AS) $\times 1510$. 

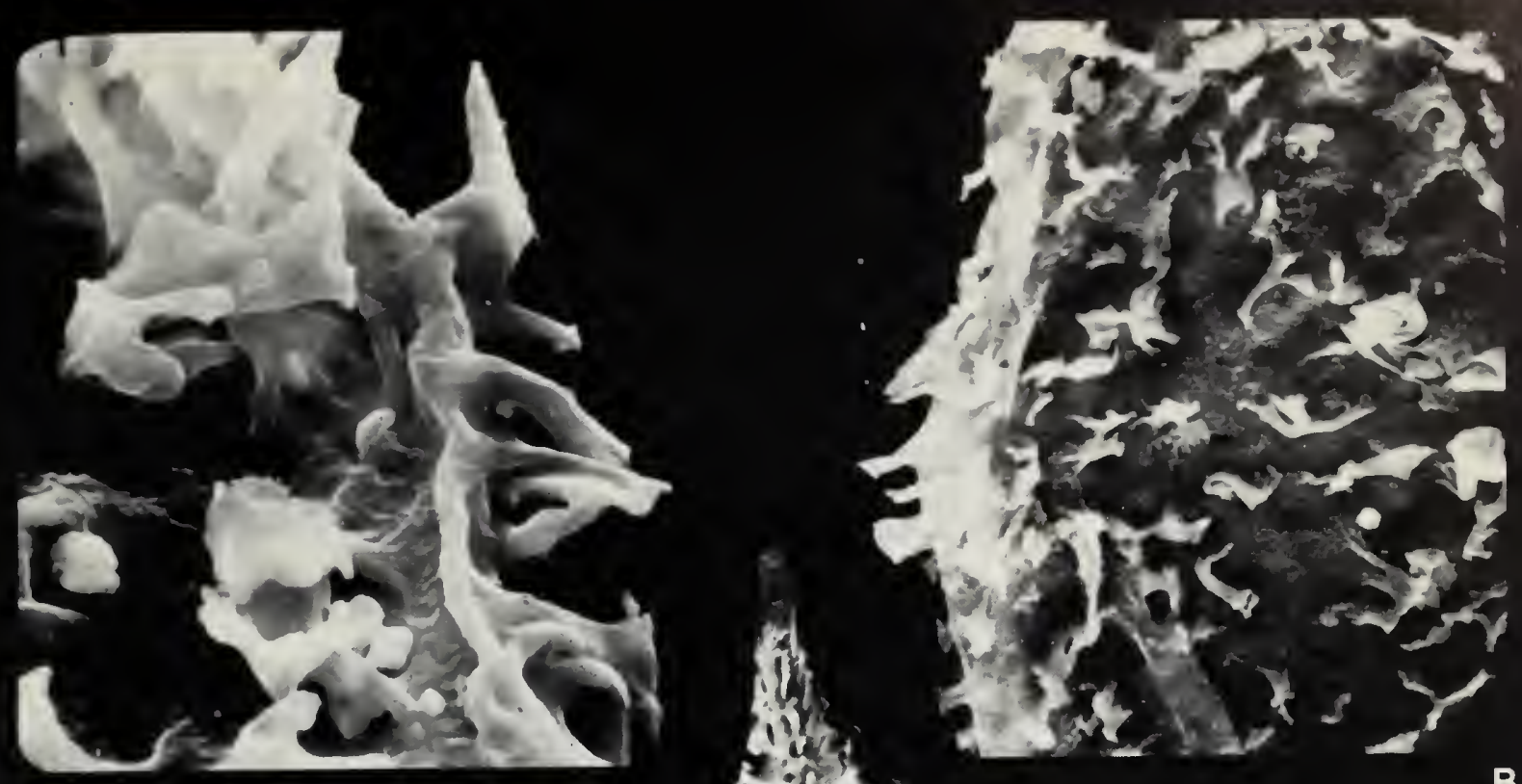

A \$ $\$$

sitiset

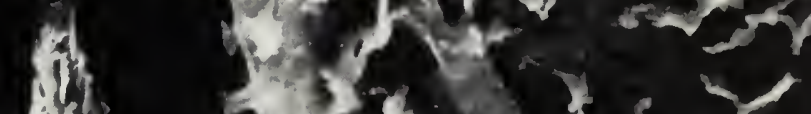

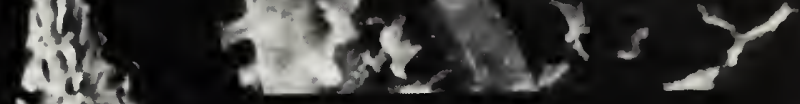

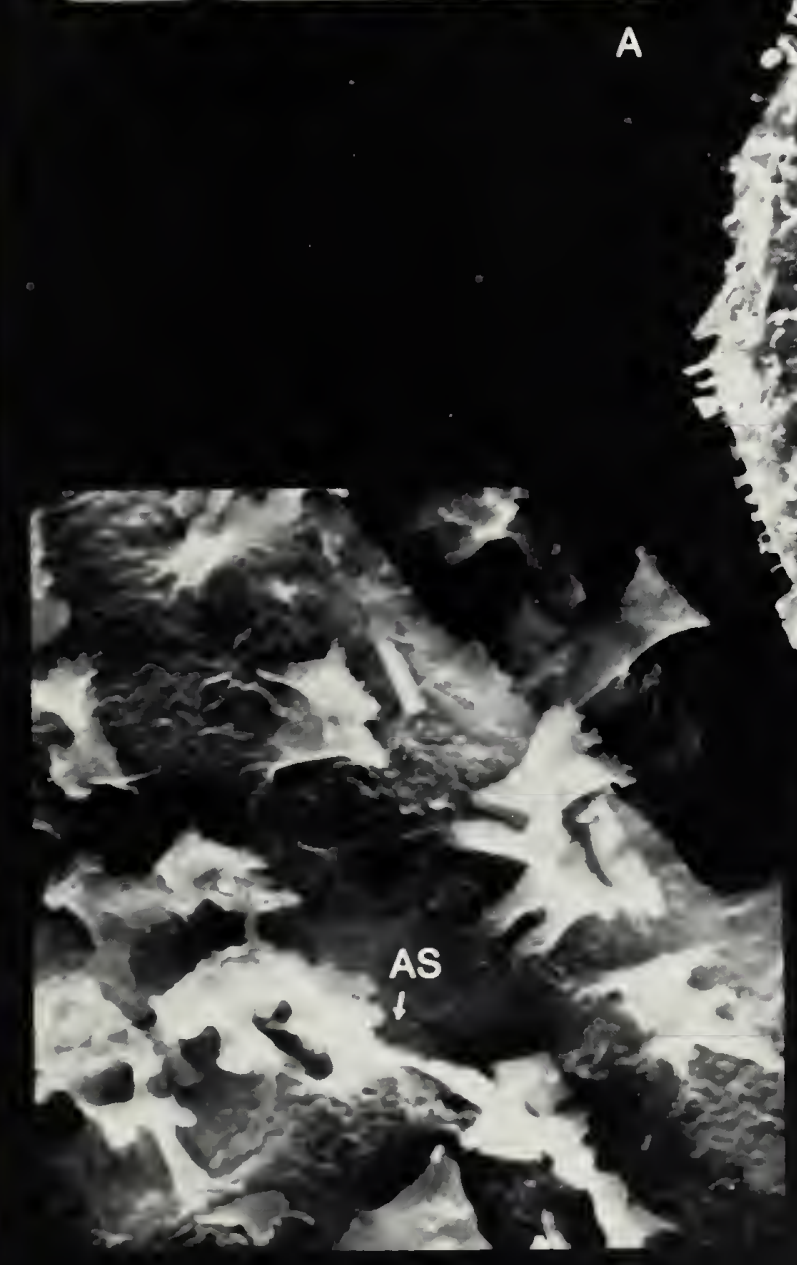


Fig. 38 A. Aptea polymorpha Eisenack 1958. Detail of ventral epitract, showing archeopyle suture, breakage along the intercalary suture (IS), and pronounced sulcal field (S). KBT 10/39.5/3, ROM 36968, 40.8/108.3, Aptian, Germany.

B, C Aptea polymorpha Eisenack 1958. Details of tabulation on the ventral area. Note the "projected" position of the flagellar pore (FP) and the unornamented ventral area. KBT 10/39.5/1, ROM 36972, 38.3/100.00, Aptian, Germany.

D, E, F Aptea polymorpha Eisenack 1958. Complete specimens, all from the German Aptian. Scale B.

D Dorsal view, KBT 10/39.5/3, ROM 36968, 62.8/107.8.

E Dorsal view, KBT 10/39.5/3, ROM 36968, 63.4/98.4.

F Ventral view. Note the pronounced omphalos (OM). KBT 10/39.5/1, ROM 36972, 38.3/100.0. 


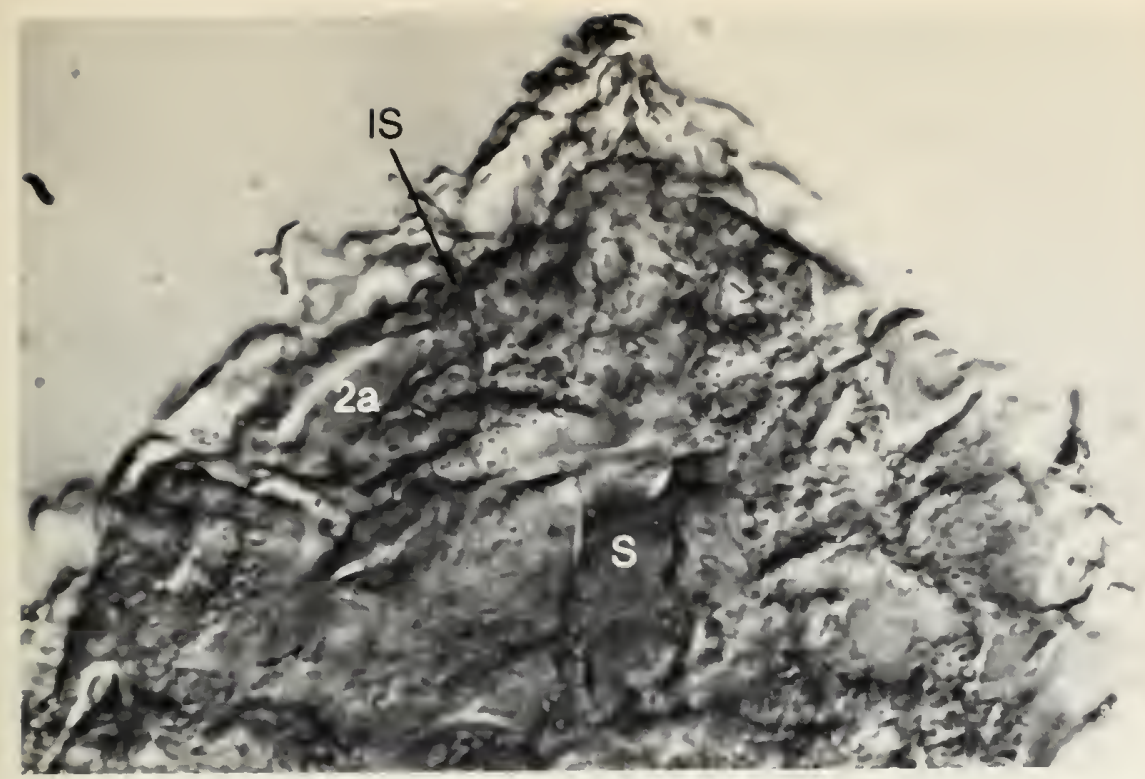

A
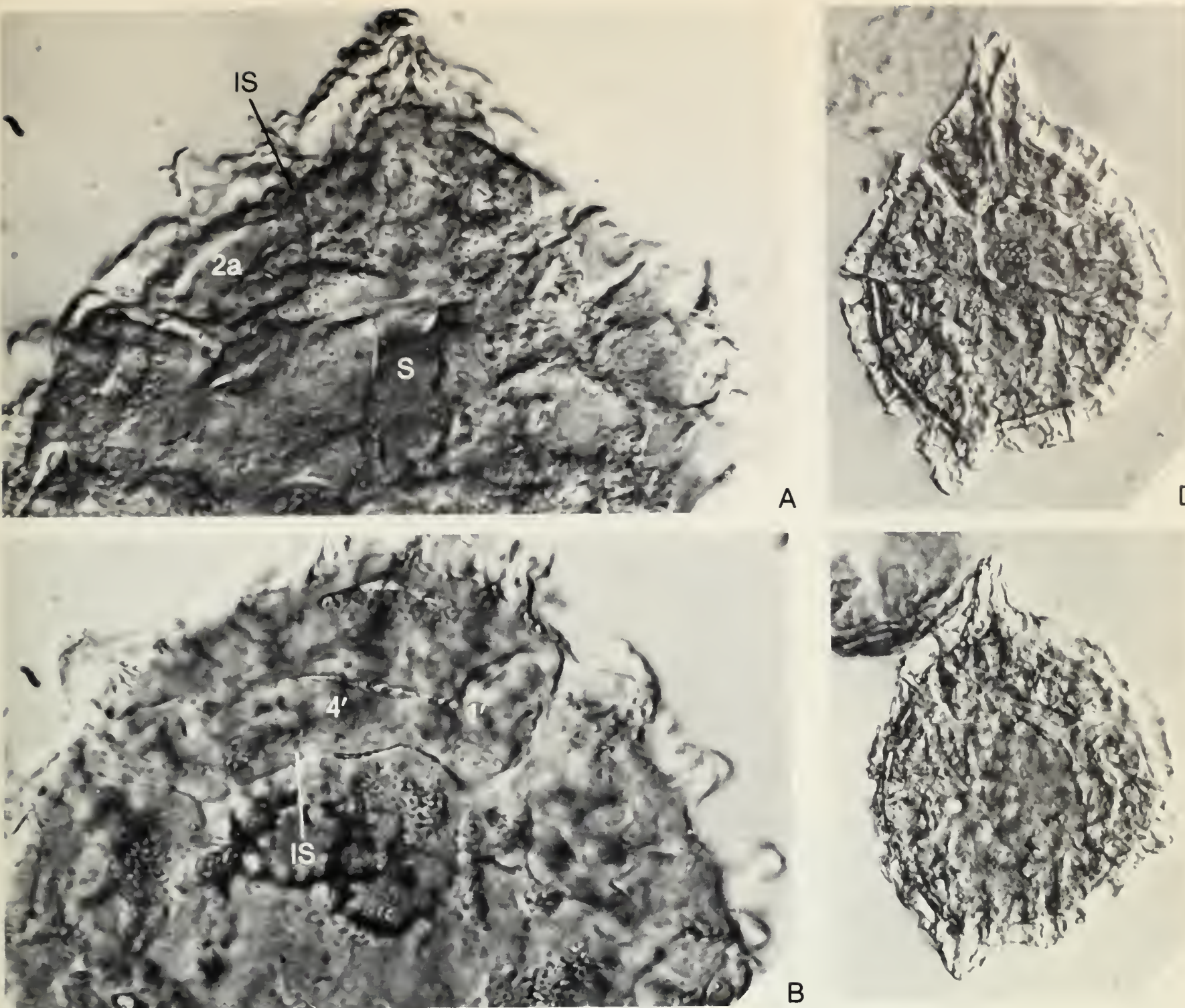

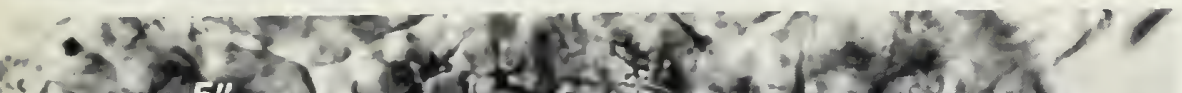

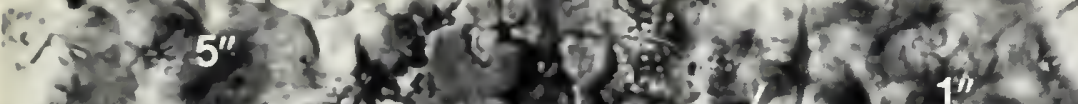

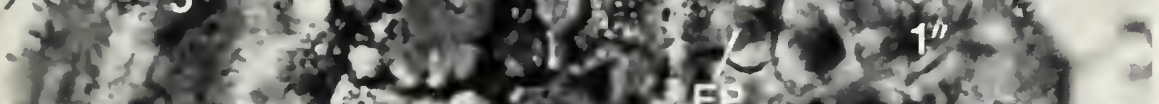

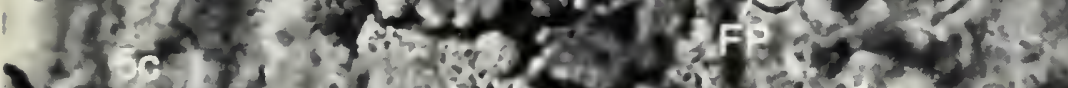

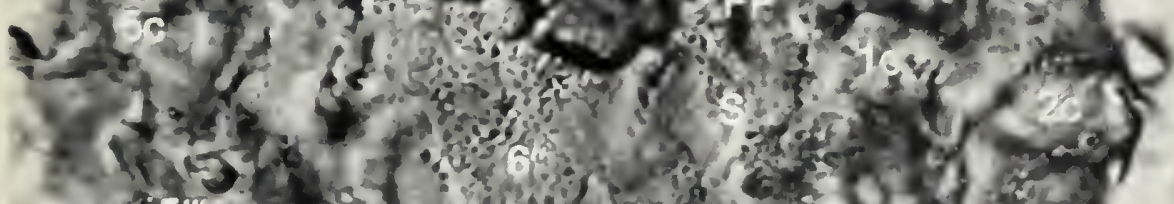

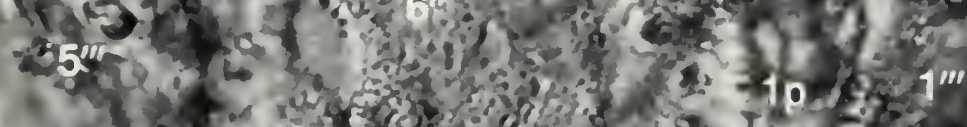

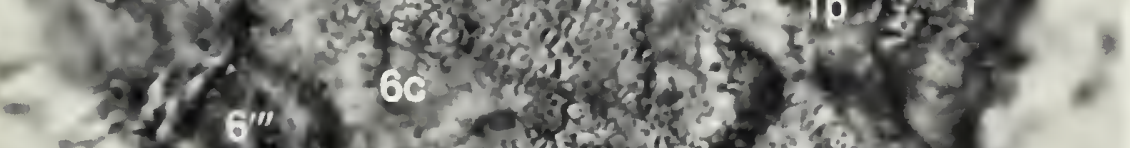

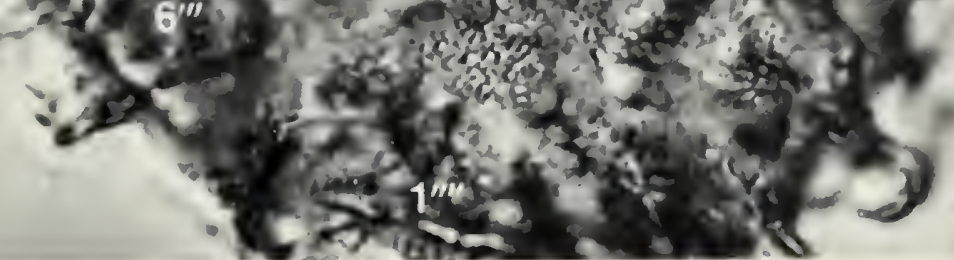


Fig. 39 A Aptea polymorpha Eisenack 1958. Dorsal view, showing asymmetrical archeopyle suture, broad pandasutural zones, and detail of ornament. KBT 10/39.5/3, ROM 36968, 62.8/107.8, Aptian, Germany.

B, C Aptea polymorpha Eisenack 1958. Dorsal view showing asymmetrical archeopyle suture, broad pandasutural zones and breakage along the suture between the two intercalary plates. KBT 10/39.5/3, ROM 36968, 63.4/98.4, Aptian, Germany.

D, E Aptea polymorpha Eisenack 1958. Complete specimens all from the German Aptian. Scale B.

D Dorsal view, KBT 10/39.5/3, ROM 36968, 45.8/106.6.

E Ventral view, KBT 10/39.5/3, ROM 36968, 40.8/108.3.

F Aptea polymorpha Eisenack 1958. Detail of E showing a faint intercalary suture (IS) and pronounced sulcal (S) and flagellar pore (FP) areas. KBT 10/39.5/3, ROM 36968, 40.8/108.3. 

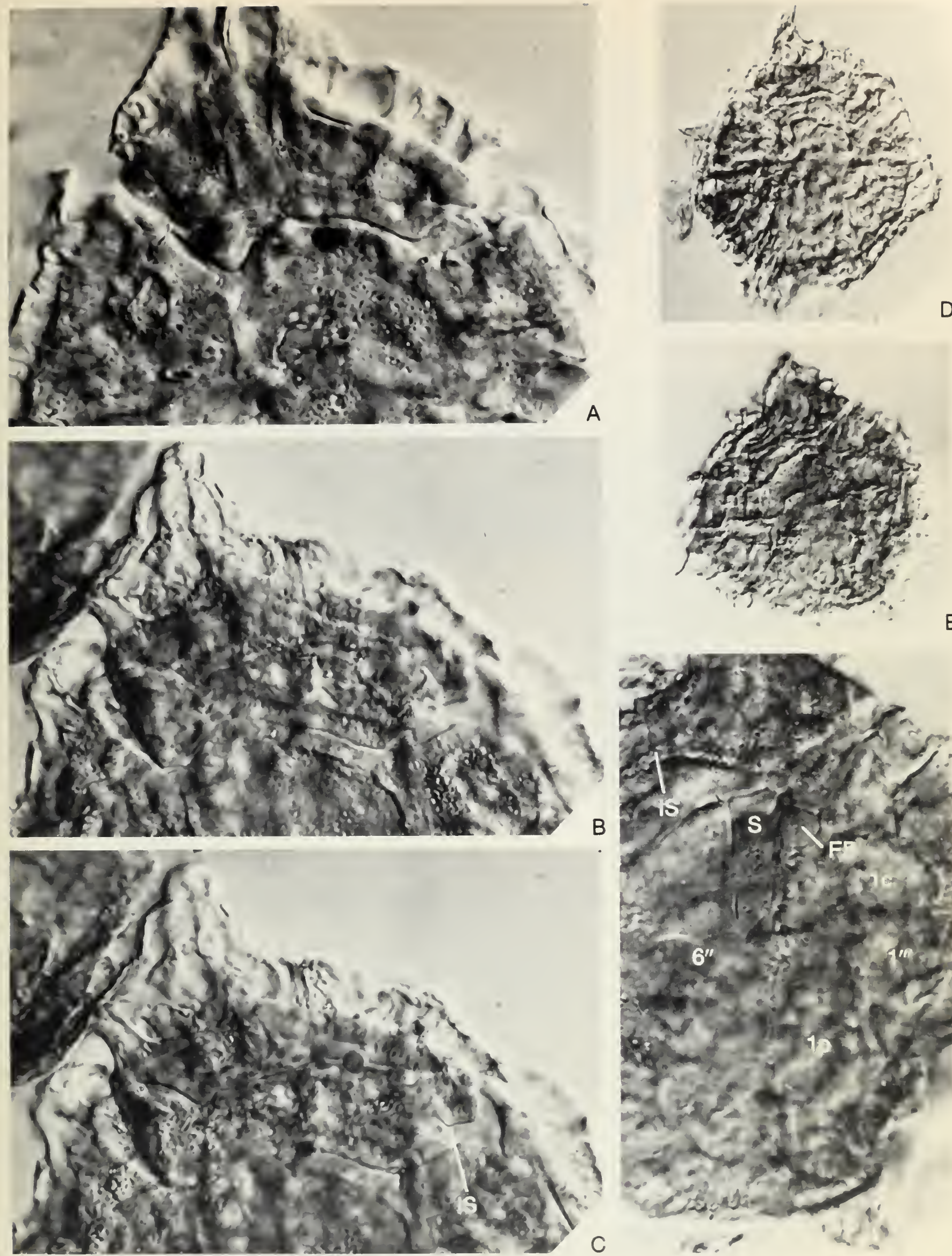

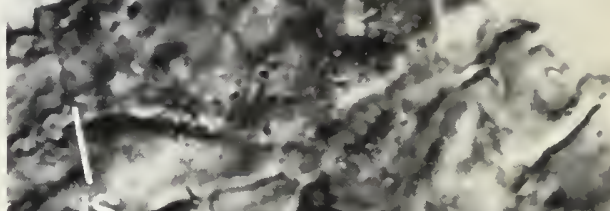

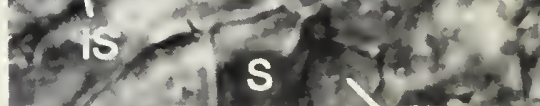
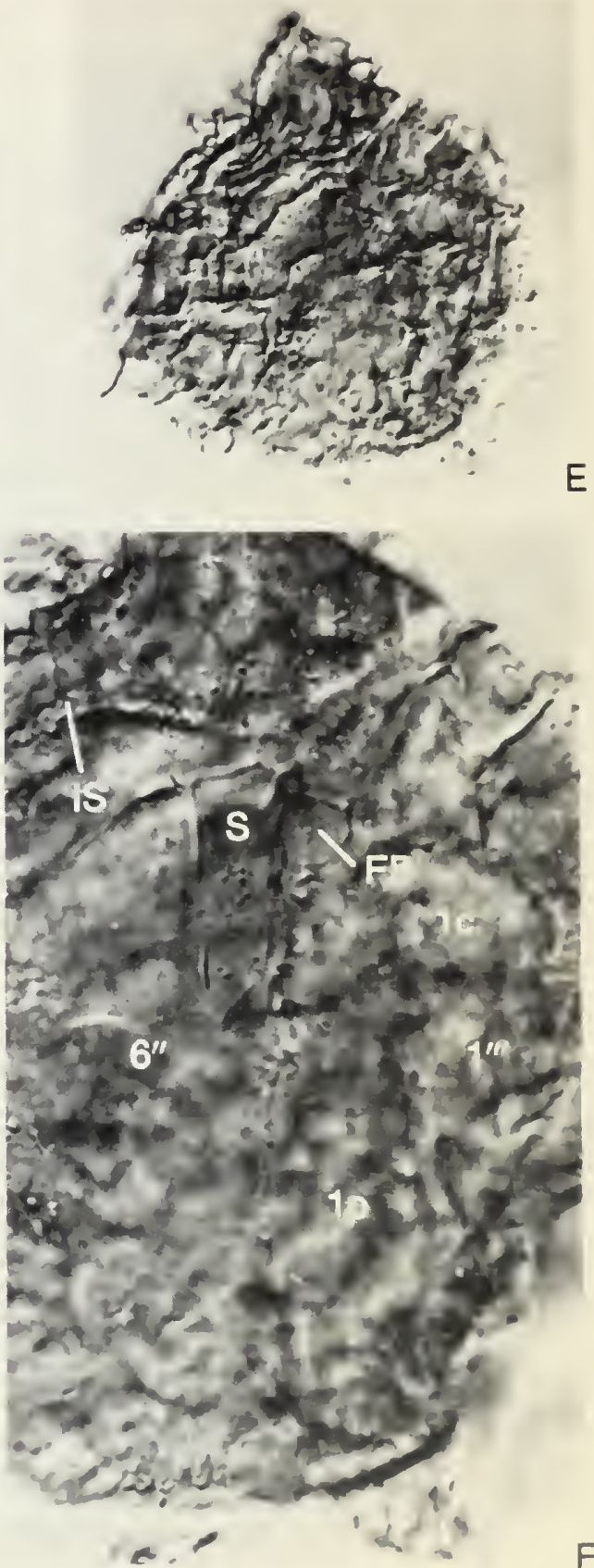
Fig. 40 A Odomochitina operculata (O. Wetzel) Deflandre 1955. Dorsal view showing asymmetrical archeopyle suture, a fold indicating the position of the cingulum (C), the sulcal groove (S) on the inside of the distal periphragm, and a pronounced omphalos (OM). Note pitted traces, possibly indicating plate boundaries. KBT 10/39.5/2, ROM 36973, 44.2/101.5, Aptian, Germany.

B, F Aptea cf. amaphrissa (Sarjeant) Stover and Evitt 1978. Gehrden 31/2, ROM 36974, 47.8/102.7, Late Barremian, Germany.

B Complete specimen with unornamented ventral area. Scale B.

F Detail, showing asymmetrical archeopyle suture (AS) and intercalary notch (IS).

C Cyclonephelium distinctum Deflandre and Cookson 1955, showing symmetrical archeopyle suture. Note the position of cingulum. KBT 10/39.5/2, ROM 36973, 35.0/107.6, Aptian, Germany.

D Cribroperidinium orthoceras (Eisenack) Davey 1969. Operculum, exhibiting intratabular ridges. Mo 551/4s, ROM 36975, 55.5/110.6, Late Albian, Germany.

E Cribroperidinium sp. Detail of dorsal area. KBT 10/39.5/1, ROM 36972, 58.2/100.0, Aptian, Germany.

G Aptea anaphrissa (Sarjeant) Stover and Evitt 1978, with asymmetrical archeopyle suture, indications of two postcingular horns. KBT 10/39.5/2, ROM 36973, 50.5/103.6, Aptian, Germany. 

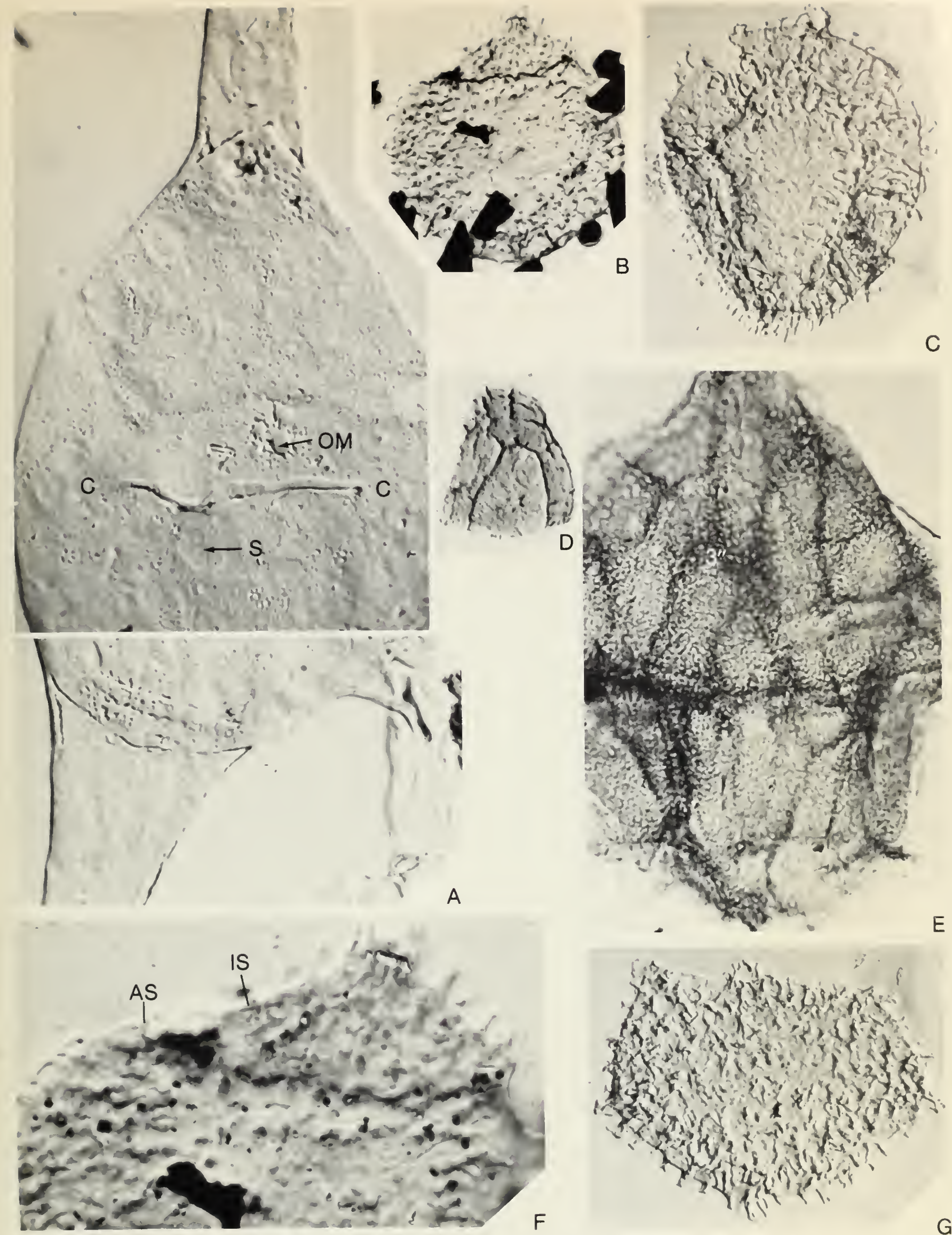

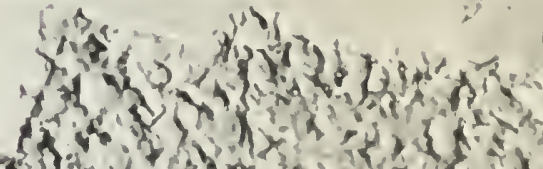

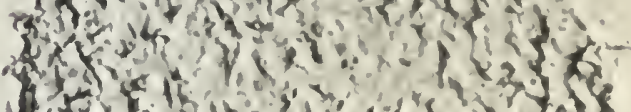

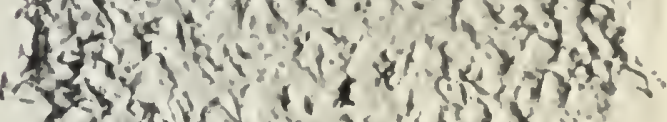
P.

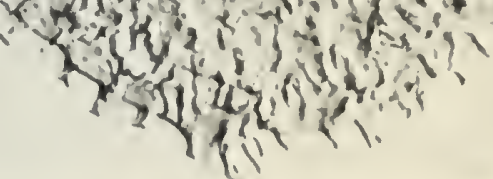





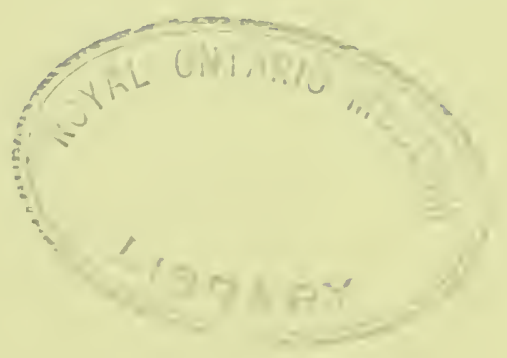


ISBN 0-88854-239-9

ISSN 0082-5093 